\title{
JOS SCHAEKEN
}

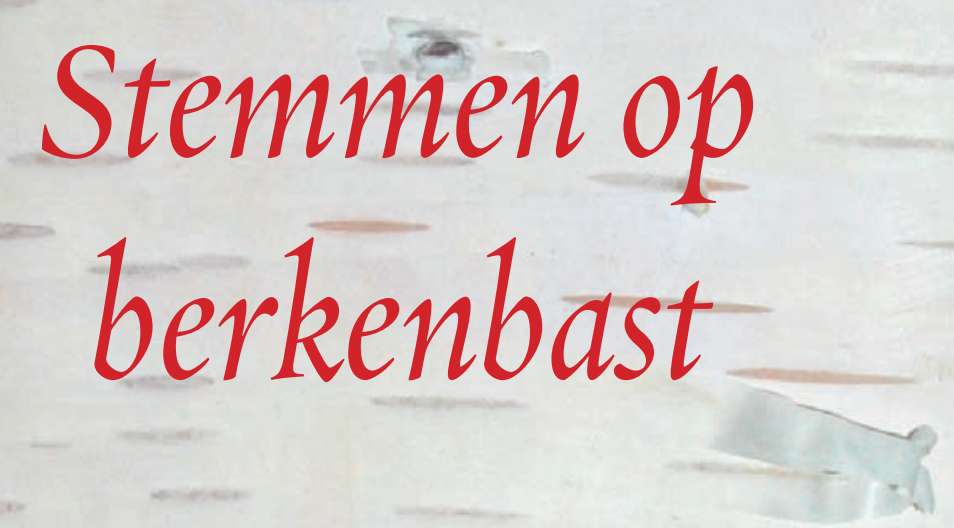

BERICHTEN UIT MIDDELEEUWS RUSLAND: DAGELIJKS LEVEN EN COMMUNICATIE 
Stemmen op berkenbast 


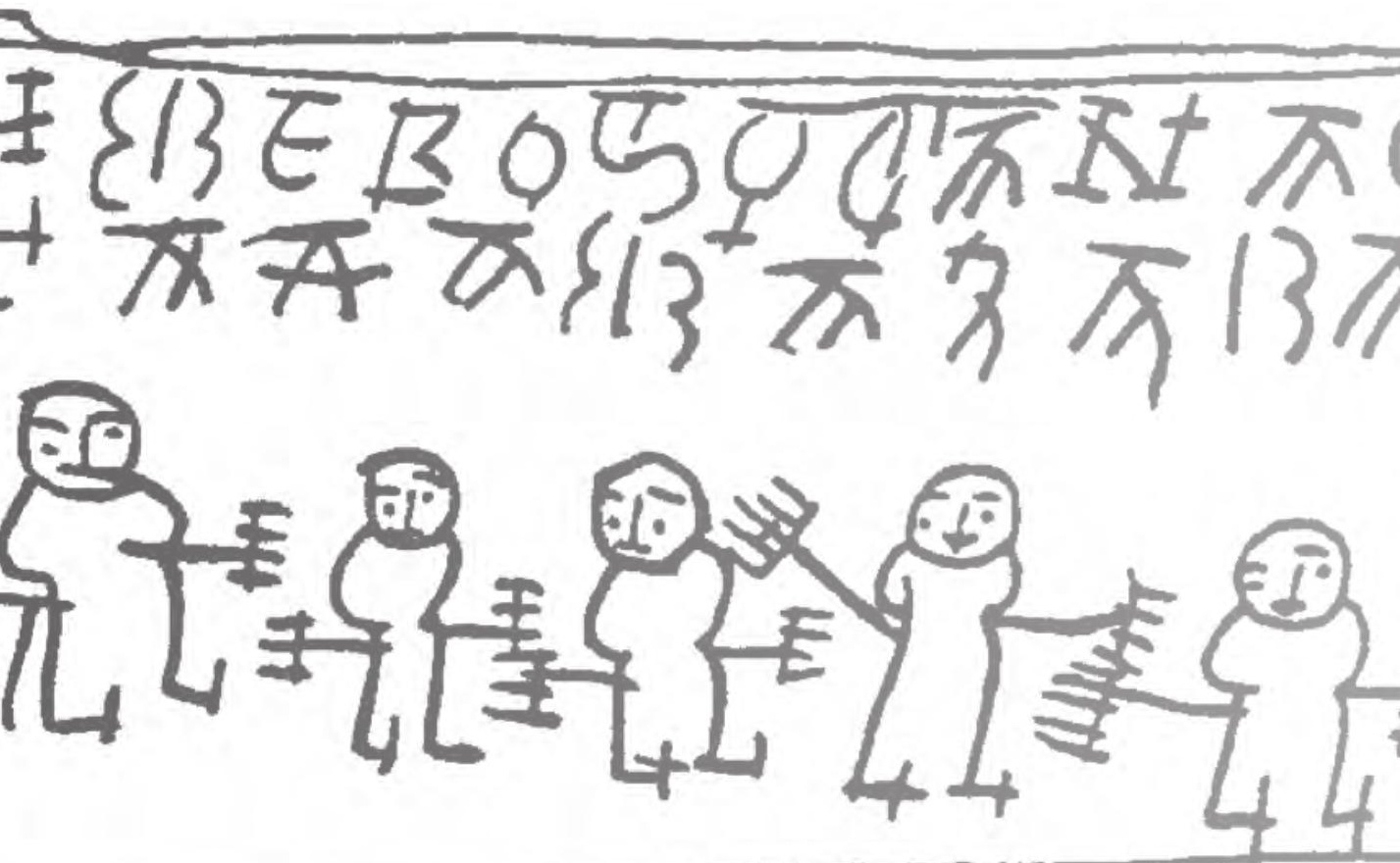


Deze publicatie verschijnt als online publicatie in de OAPEN library (www.oapen.org) en in gedrukte vorm.

OAPEN (Open Access Publishing in European Networks) is een samenwerkingsverband voor het ontwikkelen en implementeren van een duurzaam Open Access-publicatiemodel voor wetenschappelijke boeken in de geesteswetenschappen en sociale wetenschappen. De OAPEN Library heeft tot doel de zichtbaarheid en vindbaarheid van kwalitatief hoogwaardig wetenschappelijk onderzoek te verbeteren door het bijeenbrengen van peer reviewed Open Access-publicaties uit heel Europa.

Afbeelding omslag: Berkenbasttekst nr. 1 uit Novgorod

Ontwerp omslag: Sander Pinkse Boekproductie, Amsterdam

Ontwerp binnenwerk: Jos Schaeken

ISBN 9789087281618

e-ISBN 9789400600867

NUR $630 / 613$

\section{(c) $(i)()_{\mathrm{BY}} \bigodot_{\mathrm{NC}}$}

Creative Commons License CC BY NC ND

(http://creativecommons.org/licenses/by-nc-nd/3.0)

() Jos Schaeken / Leiden University Press 2012

Some rights reserved. Without limiting the rights under copyright reserved above, any part of this book may be reproduced, stored in or introduced into a retrieval system, or transmitted, in any form or by any means (electronic, mechanical, photocopying, recording or otherwise). 


\section{Inhoudsopgave}

Voorwoord 7

Inleiding: Schrijven op berkenbast 13

Historische en geografische context 13

Vindplaatsen en verspreidingsgebied 19

Datering en periodisering 24

Schrijftechniek en praktijk 29

Gebruikers en geletterdheid 32

Taal en communicatie 36

Teksten I: Dagelijks leven 41

Handel en geld 42

Recht en bestuur 54

Heren en boeren 72

Privéleven en het individu 85

Leren lezen en schrijven 101

Kerk en religie 107

Ooggetuigen van de geschiedenis 117

Buitenlands op berkenbast 124

Teksten II: Communicatie 131

De oraliteitsfactor 133

De rol van de koerier 138

Heterogene brieven 148

Sociale netwerken 160

Literatuur 169

Lijst van teksten 173

Ter verantwoording 175 



\section{Voorwoord}

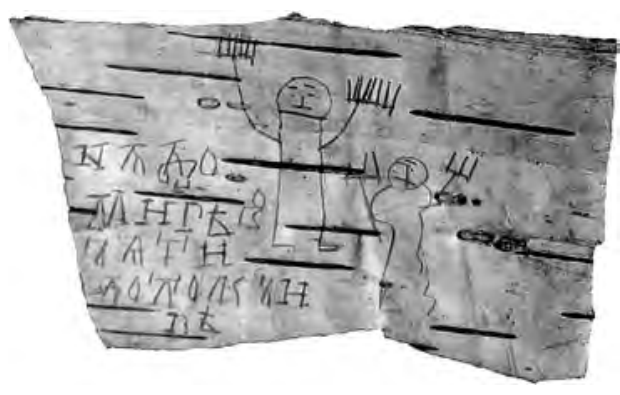

Novgorod nr. 202: Onfim leert schrijven

Op de foto hiernaast is een stukje schors van een boom te zien, om precies te zijn: een stukje van de bast van een berkenboom. Bomen die in overvloed groeien in de noordelijke streken van Rusland. Het afgebeelde stukje berkenbast komt daar vandaan, uit de stad Novgorod, of beter gezegd: Veliki Novgorod ('Groot-Novgorod'), zo'n tweehonderd kilometer ten zuiden van Sint-Petersburg.

Het is vrij eenvoudig om met een scherp voorwerp letters en figuurtjes te krassen op een stuk berkenbast. Je kunt het gebruiken om er aantekeningen voor jezelf op te maken, maar ook om er een bericht aan iemand op te schrijven. Dat is wat er gebeurde in Novgorod en omstreken in de Middeleeuwen, toen papier nog duur en niet wijdverspreid was en het kostbare perkament natuurlijk niet gebruikt werd voor een kleine notitie of een kort briefje. Berkenbast kost niets en is prima schrijfmateriaal.

Tijdens archeologische opgravingen in Novgorod en andere oude Russische steden zijn de afgelopen zestig jaar meer dan elfhonderd stukjes berkenbast met tekst erop gevonden. De eerste tekst werd in Novgorod opgegraven op 26 juli 1951, door Nina Fjodorovna Akoelova, in de oude Cholopja Oelitsa, de 'Horigenstraat' (zie de foto op p. 84). Sindsdien komen er bijna ieder jaar meer bij, want er wordt elk zomerseizoen verder gegraven naar berkenbastteksten. De foto hierboven geeft er een weer (nr. 202, gevonden in 1956) waarvan we de naam van de schrijver kennen. Hij heette Onfim en moet een kind geweest zijn toen hij in het midden van de dertiende 
eeuw het tekstje met tekeningen maakte. Onfims verdere 'oeuvre' op berkenbast komt uitvoerig aan de orde op p. 101 e.v.

De hier gepresenteerde verzameling van teksten geeft een overzicht van de verscheidenheid aan onderwerpen die op berkenbast ter sprake komen en geeft tevens inzicht in de manier waarop brieven werden opgesteld, overgebracht en gelezen. De verzameling zou onmogelijk tot stand hebben kunnen komen zonder gebruikmaking van de resultaten van het intensieve onderzoek dat al decennialang in Rusland wordt verricht naar berkenbastteksten. Het betreffende onderzoeksveld heeft in het Russisch een aparte naam: berestologija, 'berestologie'. Het woord is afgeleid van beresta 'berkenbast'. Letterlijk vertaald betekent berestologija dus 'berkenbastologie'.

De berestologie is een interdisciplinair onderzoeksgebied waar archeologen, filologen, taalkundigen en historici bij betrokken zijn. De archeologen verrichten de feitelijke opgravingen en doen onderzoek naar de ouderdom van het materiaal en de materiële context waarin het is gevonden. Filologen en taalkundigen zijn degenen die de berkenbastteksten in eerste instantie interpreteren. De eerste groep concentreert zich vooral op de tekst zelf (schrijfwijze, woordindeling en dergelijke) en de tweede op de taal van de tekst (grammatica, woordbetekenissen, enz.). De wisselwerking tussen beide disciplines (vaak verenigd in een en dezelfde onderzoeker), in combinatie met de archeologische gegevens en verdere input van historici die kennis hebben van de bredere context, levert vervolgens een zo optimaal mogelijke interpretatie op van wat de boodschap is die op berkenbast wordt gecommuniceerd.

Dit boek is een bewerking en presentatie in het Nederlands van de vele onderzoeksgegevens die in met name Russische boeken en artikelen gepubliceerd zijn. Hoewel hiernaar meer in detail wordt verwezen in de literatuurverwijzingen (p. 169 e.v.), moet op deze plek meteen het monumentale werk Drevnenovgorodskij dialekt ('Het Oudnovgorodse dialect') van Andrej A. Zaliznjak uit 2004 (2e editie) genoemd worden; hierin staan nagenoeg alle essentiële zaken van het vakgebied uitgelegd. Echter, voor een breder publiek, 
zeker voor degenen die het Russisch niet beheersen, is dit vakgebied moeilijk toegankelijk. Er wordt veel kennis op het terrein van de Russische filologie en historische taalkunde verondersteld en zelfs voor de 'doorsnee slavist' vergt de interpretatie van berkenbastteksten de nodige wetenschappelijke inspanningen, zelfs met vertalingen in het modern Russisch bij de hand. Deze zijn vaak bijzonder subtiel en laten soms ook de precieze duiding van de tekst in het midden.

De beperkte toegankelijkheid tot het unieke materiaal is jammer, want verzamelingen van persoonlijke brieven en andere private documenten uit de Middeleeuwen zijn schaars. Zeker in de omvang zoals die is overgeleverd op berkenbast uit het middeleeuwse Rusland. Persoonlijke documenten zijn meer en meer in de belangstelling gekomen in historisch en historisch-taalkundig onderzoek dat wel History from below genoemd wordt. Het zijn niet alleen de kronieken en andere publieke werken in vergulde perkamenten handschriften, aan de hand waarvan we de (taal)geschiedenis kunnen reconstrueren. Private berichten op papyrus, houten wastafeltjes en staafjes, berkenbast en later ook papier verschaffen ons vaak een preciezer inzicht in hoe historische gebeurtenissen geduid moeten worden en hoe taalveranderingen in de praktijk hebben plaatsgevonden.

In het eerste deel van dit boek worden aan de hand van berkenbastteksten portretten geschetst van het Dagelijks leven (p. 41 e.v.). Hoewel het om teksten gaat van een half tot heel millennium oud, komt de inhoud vaak zeer vertrouwd over. Als Boris in brief nr. 43 (p. 85) het niet over een "man op een hengst", maar over een man in een auto zou hebben gehad, dan zouden we kunnen denken dat we met een hedendaags bericht te maken hebben, per e-mail of zelfs sms, want nr. 43 bevat slechts 130 'tekens' In zijn geschiedenis van de vroegste Nederlandse literatuur, Stemmen op schrift, gebruikt Frits van Oostrom voor zijn "tijdreis langs mensen uit de Middeleeuwen" het motto: "wat een vreemde wereld - en wat lijken ze op ons" (2006, p. 24). Het motto is zonder meer ook van 
toepassing op onze alternatieve tijdreis middels berkenbastteksten, op tweeduizend kilometer afstand van Nederland. Ook in Rusland kunnen we de stemmen horen uit een middeleeuwse samenleving en cultuur.

In het tweede deel van dit boek - Communicatie (p. 131 e.v.) ligt de nadruk op de pragmatiek, d.w.z. de manier waarop in berkenbastbrieven informatie wordt overgedragen van de afzender(s) op de geadresseerde(n). Er zijn nogal wat gevallen waarin we in principe alle formele aspecten van de tekst weten: de spelling, de grammaticale details en de woordbetekenissen. Wat we echter niet weten is: Wat staat er eigenlijk? Wat wordt er aan wie meegedeeld? Recent onderzoek heeft uitgewezen dat er op berkenbast verrassende communicatiestrategieën gehanteerd werden, waarbij typisch mondelinge elementen van communicatie deel uitmaken van de schriftelijke mededeling. Deze nieuwe inzichten zijn van breder belang voor ons begrip van het proces van verschriftelijking in samenlevingen die eerder alleen mondeling boodschappen konden overbrengen.

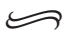

Het onderzoek naar berkenbastteksten is meer dan twintig jaar geleden in Nederland onder de aandacht gebracht door mijn Leidse collega Willem Vermeer. Hij heeft internationaal pionierswerk verricht op het terrein van de historische taalkunde en de sociolinguistiek. Vermeer heeft me destijds enthousiast gemaakt voor het onderzoeksgebied en me laten inzien hoe fascinerend en tegelijkertijd gevaarlijk het is. Berkenbastteksten laten vaak veel ruimte voor (te) fantasievolle gedachten over hun taal, inhoud en context. Ockhams scheermes is een onmisbaar gereedschap bij het onderzoek.

Ik dank het Leiden University Centre for Linguistics voor de financiële ondersteuning van mijn onderzoeksreizen naar Novgorod. De vele gesprekken in Novgorod met Russische experts op het terrein van de berestologija waren uiterst leerzaam, stimulerend en daarnaast ook bijzonder prettig. In het bijzonder wil ik Aleksej A. 
Gippius, Valentin L. Janin, Elena A. Rybina en Andrej A. Zaliznjak noemen. Veel dank ben ik ook verschuldigd aan mijn Amerikaanse collega Daniel E. Collins voor de waardevolle input die hij heeft gegeven in het eindstadium van dit boek. Voor het proeflezen van de Nederlandse tekst waren de kritische opmerkingen van Simeon Dekker, Elna Kranenburg en in het bijzonder Janneke Kalsbeek buitengewoon nuttig. Ik dank ook Leiden University Press voor de prettige samenwerking en de twee reviewers voor hun aanbevelingen. Uiteraard zijn alle gebreken van dit boek voor mijn eigen rekening: a vo tomo božeja volja i tvoja (berkenbasttekst nr. 6 uit Pskov, laatste zin, zie p. 45).

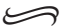

In de hoofdtekst van dit boek wordt het gangbare Nederlandse transliteratiesysteem voor het Russisch gebruikt (bijvoorbeeld: $u=$ tsj, $u_{1}=$ sjtsj, $y=$ oе; Глушица $=$ Gloesjitsa, Мишиничи = Misjinitsji). In de literatuurverwijzingen (p. 169 e.v.) is het internationale wetenschappelijke systeem aangehouden $\left(u=\check{c}, \mathfrak{w}_{\mathbf{s}}=\check{c} \check{c}, y=u\right.$; Глушиц $a=$ Glušica, Мишиничи = Mišiniči, enz.), in navolging van universitaire bibliotheken. Voor een verdere toelichting op de verschillende transliteraties zie www.schaeken.nl/lu/onderwijs/extra/ cyrtrans.pdf. 



\section{Inleiding: Schrijven op berkenbast}

\section{Historische en geografische context}

Hieronder volgt eerst een tijdbalk met de hoofdmomenten in de (cultuur)geschiedenis van Novgorod.

859/862 Eerste vermeldingen van Novgorod in de oudste Russische kronieken; komst naar Novgorod van de Varjaag (Noorman) Rjoerik, grondlegger van de Rjoerik-dynastie die duurde tot 1598

882 Oprichting van de residentie van de Novgorodse vorsten in Gorodisjtsje, op drie kilometer afstand van de stad; volgens de kronieken vertrekt een zekere Oleg met de nog jonge zoon van Rjoerik, Igor, en neemt Kiëv in

ca. 910 Vroegste archeologische resten in Novgorod

947 Uitbreiding van het Novgorodse territorium onder Olga van Kiëv, de vrouw van Igor

988 Doop van grootvorst Vladimir I van Kiëv (kleinzoon van Igor); traditionele kersteningsdatum van Rusland

989 Wijding van Ioakim (Joachim), eerste bisschop van Novgorod

begin XI Regeerperiode van grootvorst Jaroslav de Wijze, zoon van Vladimir I; oprichting van de vorstelijke residentie aan de Handelszijde van de stad (Jaroslavs Hof); ontstaan van de Novgorodse Codex (zie p. 103), het oudste Russische 'boek'

1018 Bekrachtiging onder Jaroslav de Wijze van de oudste redactie van het Russische wetboek, de Roesskaja Pravda

1025-50 Periode van de tot nu toe oudste berkenbastteksten uit Novgorod (zie p. 27) 
$1034 \quad$ Annexatie van Pskov door Novgorod

1044 Eerste vermelding in de kronieken van de bouw van een houten kremlin in Novgorod

1045-50 Bouw van de Sofia-Kathedraal in het kremlin van Novgorod

1056-57 Ontstaan van het oudste precies gedateerde Slavische perkamenten handschrift: het Ostromir-Evangelie, vervaardigd door de diaken Grigori voor de posadnik (stadhouder) van Novgorod, Ostromir

ca. 1113 Ontstaan van de Nestorkroniek (ook: Verhaal van Voorbije Jaren) in Kiëv, de oudste van een groep Russische kronieken

begin XII Oprichting van de eerste kloosters in Novgorod (Antoniëv en Joerjev); bouw van de Gotenhof - handelspost voor kooplieden uit Visby op Gotland - met de SintOlafskerk op de Handelszijde van de stad

1136 De Novgoroders verjagen vorst Vsevolod Mstislavitsj; begin van de Novgorodse Republiek; vorsten werden 'onder contract' ( rjad) en met goedkeuring van de vetsje (volksvergadering) uit andere vorstendommen gehaald

eind XII Bouw van de Peterhof - voor Duitse kooplieden, later ook Hanzekantoor - met de Sint-Peterskerk op de Handelszijde van de stad

1237-42 Tataars-Mongoolse invasie; Kiëv valt in 1240; Novgorod blijft onafhankelijk, maar de rest van Rusland wordt onderworpen; de periode van het 'Tataarse juk' (Rijk van de Gouden Horde) duurt tot 1480

1240 Overwinning van vorst Alexander Nevski van Novgorod op de Zweden in de slag aan de rivier de Neva

1242 Overwinning van Alexander Nevski op de Duitse Orde in de Slag op het IJs van het Peipusmeer (Tsjoedskoje ozero), nabij Pskov

mid. XIII Eerste deel van de oudste overgeleverde kopie van de 
Eerste Novgorodse Kroniek; inclusief latere aanvullingen wordt de geschiedenis van Novgorod van 1016 tot 1477 beschreven

eind XIII Pskov maakt zich los van Novgorod, hoewel zijn onafhankelijkheid pas in 1348 formeel bekrachtigd wordt

1478 Annexatie van Novgorod door Moskou onder Ivan III; deportatie van Novgorodse landbezitters naar andere gebieden van Rusland

1494 Ivan III sluit het Hanzekantoor in de Peterhof in Novgorod

eind XV Periode van de tot nu toe jongste berkenbastteksten uit Novgorod (zie nr. 495, p. 51)

$1570 \quad$ Novgorod wordt geplunderd en ontvolkt onder Ivan IV (de Verschrikkelijke)

1611-17 Bezetting van Novgorod door de Zweden in de 'Tijd der Troebelen'

1932 Begin van systematische archeologische opgravingen in Novgorod

195126 juli: de eerste berkenbasttekst wordt gevonden; zie de foto op p. 84 (in 1966 volgt de eerste berkenbasttekst uit Staraja Roessa, in 1985 de eerste uit Torzjok)

1992 Novgorod wordt opgenomen in de Werelderfgoedlijst van de UNESCO

201021 juli: berkenbasttekst nr. 1000 (zie p. 52) wordt opgegraven

De stad Novgorod wordt doorsneden door de rivier de Volchov. Deze stroomt vanuit het Ilmenmeer, ten zuiden van de stad, naar het noorden en mondt na ruim tweehonderd kilometer uit in het Ladogameer, noordoostelijk van Sint-Petersburg. Via de rivier de Neva is het Ladogameer verbonden met de Finse Golf en de Oostzee.

In Novgorod heten de twee zijden van de Volchov de Sofiazijde, op de linkeroever, en de Handelszijde, op de rechter. De Sofiazijde bestaat uit drie wijken: de Nerev en de Ljoedin wijk in het noorden 


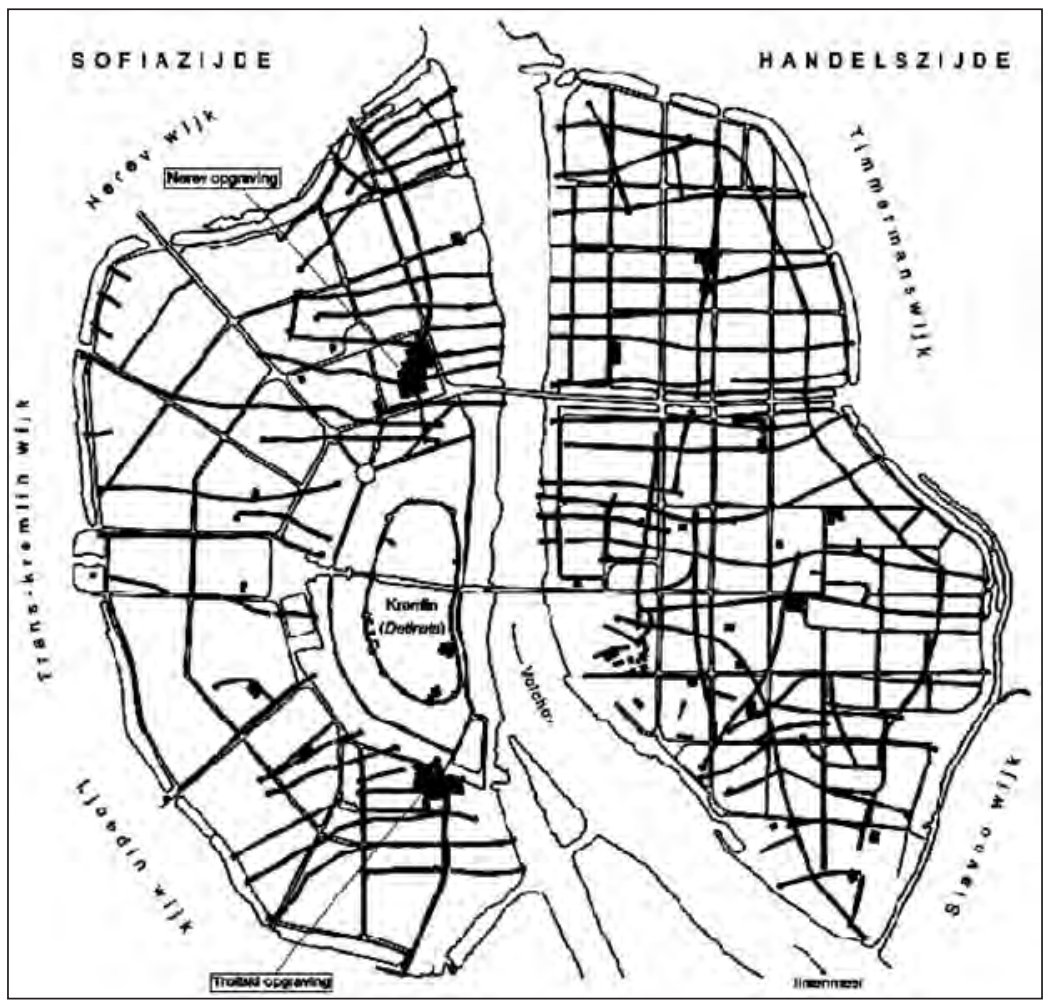

Plattegrond van Novgorod, met weergave van het middeleeuwse stratennet (in grijs), de moderne straten (in zwart) en de opgravingsplaatsen (zwarte blokjes)

resp. zuiden, met daartussen de Trans-kremlin wijk. Op de rechteroever ligt in het noorden de Timmermanswijk en in het zuiden de Slavno wijk. Verschillende delen van de stad worden vermeld in berkenbastbrief nr. 954 (zie p. 92).

De Sofiazijde is genoemd naar de Sofia-Kathedraal, gelegen in het kremlin van de stad (ook wel Detinets genoemd in het Russisch). De andere zijde was het economisch centrum van de stad; hier, in de bocht van de rivier, waar het water langzamer stroomde, legden de schepen aan. Er bevonden zich de marktplaats en ook de semipermanente verblijfsposten van buitenlandse handelaren, uit 


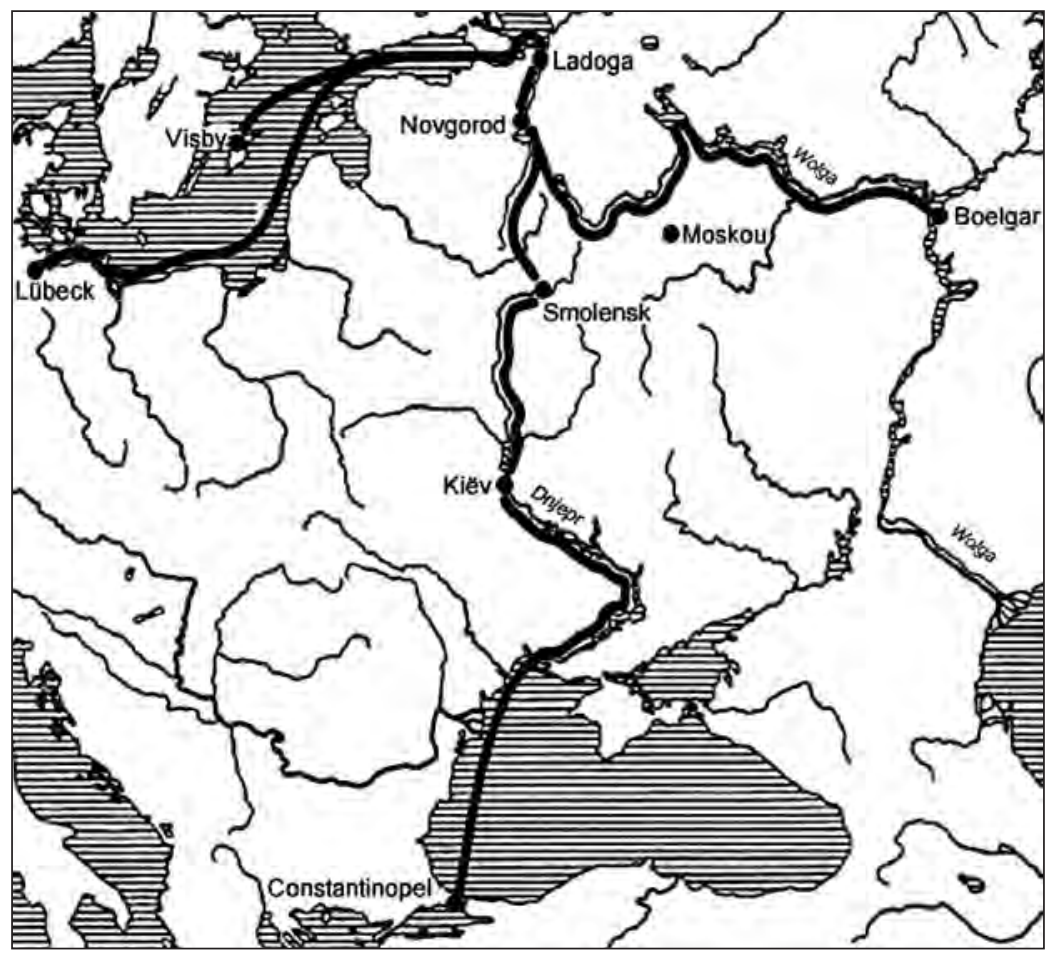

Belangrijkste handelsroutes van Novgorod, met een noord-zuidroute via o.a. de Dnjepr (de zogenaamde route 'Van de Varjagen naar de Grieken') en een oostwestroute via o.a. de Wolga, van de Kaspische Zee tot Noord-Europa

Scandinavië (voornamelijk Gotland; de Gotenhof) en Duitsland. De Duitse Hanzekooplieden, gevestigd in de Peterhof, hadden zelfs hun eigen interne wetgeving, overgeleverd in de zogenaamde Novgorodse Schra. Vanaf het eind van de twaalfde eeuw bestaan er al Duits-Novgorodse handelsverdragen, waarin van Russische zijde geregeld vertegenwoordigers genoemd worden die ook in berkenbastteksten voorkomen. In het vroegste verdrag komen we meteen Mirosjka tegen, die de afzender is van brief nr. 502 (zie p. 61). In een jonger verdrag (1342) over de handel in was figureren in het Duitse afschrift 'de hertighe Astaphie unde de olderman Cider der 
koplude'. Deze Cider, 'oudste der kooplieden', kan geïdentificeerd worden met de koopman Sidor uit brief nr. 364 (p. 96). Sidor schrijft zelf een brief aan Ostafja (zie p. 164), d.w.z. 'de hertighe Astaphie'.

Het Novgorodse handelscentrum was er niet alleen voor de stad, maar voor de hele staat. Deze had in de veertiende en vijftiende eeuw een enorme omvang gekregen: tweeduizend kilometer van west naar oost, van het huidige Estland tot achter het Oeralgebergte, en twaalfhonderd van noord naar zuid, van het schiereiland Kola tot ongeveer honderd kilometer ten westen van Moskou. De stad zelf had in de dertiende eeuw naar schatting twintig- tot dertigduizend inwoners; alleen Kiëv was significant groter in middeleeuws Rusland.

Novgorod kon profiteren van zijn uiterst gunstige ligging op het kruispunt van belangrijke waterwegen, die de Oostzee met de Zwarte Zee en via de Wolga met de Kaspische Zee en de Zijderoute verbonden (zie de kaart op p. 17). Byzantijnse en oriëntaalse luxegoederen vonden via Novgorod hun weg naar het westen, zoals ook eigen exportproducten, waarvan de belangrijkste uit het achterland kwamen: honing, was en vooral bontwerk in alle soorten (van duur sabelbont tot goedkope eekhoornvelletjes; zie nr. 722, p. 42). Deze spullen kwamen voor een groot deel binnen via verschillende heffingen (zie bijvoorbeeld nr. 136, p. 74). Geïmporteerd vanuit het westen werd er van alles: zilver en andere metalen, laken, barnsteen, wapens, en ook levensmiddelen zoals graan (vergelijk nr. 424, p. 47), zout, haring en wijn.

Dat Novgoroders verre reizen maakten voor 'Griekse' of 'overzeese' goederen blijkt onder andere uit brief nr. 1009 (p. 52). Een nog tastbaarder bewijs zijn de vele cyrillische inscripties van de elfde tot veertiende eeuw, in Oudnovgorodse taal en spelling, op de marmeren muren en balustrades van de Hagia Sophia in Istanbul; voor Russische gelovigen in de Middeleeuwen de belangrijkste kathedraal van het christelijke oosten. 


\section{Vindplaatsen en verspreidingsgebied}

Berkenbastteksten zijn gevonden in de plaatsen die op de kaart op p. 20 zijn weergegeven en waarachter getallen worden vermeld. Wat we op dit moment hebben, na het archeologische zomerseizoen van 2011, zijn in totaal 1121 items uit twaalf verschillende steden.

Het getal 1121 behoeft een nadere toelichting: 1121 vondsten betekenen niet precies 1121 verschillende teksten. Elke berkenbast waar tekst op staat krijgt een nummer na het moment van opgraving. Soms blijkt echter dat twee nummers, die in verschillende jaren zijn opgegraven, samen één tekst vormen. Dit is bijvoorbeeld het geval bij nr. 562 uit Novgorod, gevonden in 1977, en nr. 607, vijf jaar later gevonden; samen bleek het om een doorlopende tekst te gaan (zie nr. 607/562, p. 67). Ook zijn er een paar langere teksten, geschreven op meerdere stukjes berkenbast, die samen een geheel vormen, maar waarbij elk stuk een apart nummer heeft gekregen (zie bijvoorbeeld nr. 519/520, p. 70). Daar staat weer tegenover dat soms een en hetzelfde nummer twee zelfstandige teksten bevat, zoals in het geval van nr. 736, waar we te maken hebben met een brief met op de achterkant het antwoord (zie p. 49).

De meeste van de twaalf steden waar berkenbastteksten zijn gevonden liggen in het huidige Rusland, behalve Vitebsk en Mstislavl (Wit-Rusland) en Zvenigorod in Galicië (Oekraïne). De vondsten buiten Rusland zijn in aantal marginaal (vijf stuks), terwijl degene van Russische bodem voor het overgrote deel opgegraven zijn in Novgorod: 1018 items tot nu toe, d.w.z. ongeveer negentig procent van het totaal. Tel je daar de vondsten bij op in andere steden die behoorden tot de middeleeuwse stadstaat Novgorod en tot hetzelfde historische taalgebied (Staraja Roessa, Torzjok en aanvankelijk ook Pskov), dan stijgt het percentage berkenbastvondsten uit het Novgorodse land tot 97 procent. De vragen die dan natuurlijk onmiddellijk opkomen zijn: waarom komen bijna alle vondsten uit Novgorod en omstreken, en, hebben we enig idee van wat nog waar op ons ligt te wachten? 


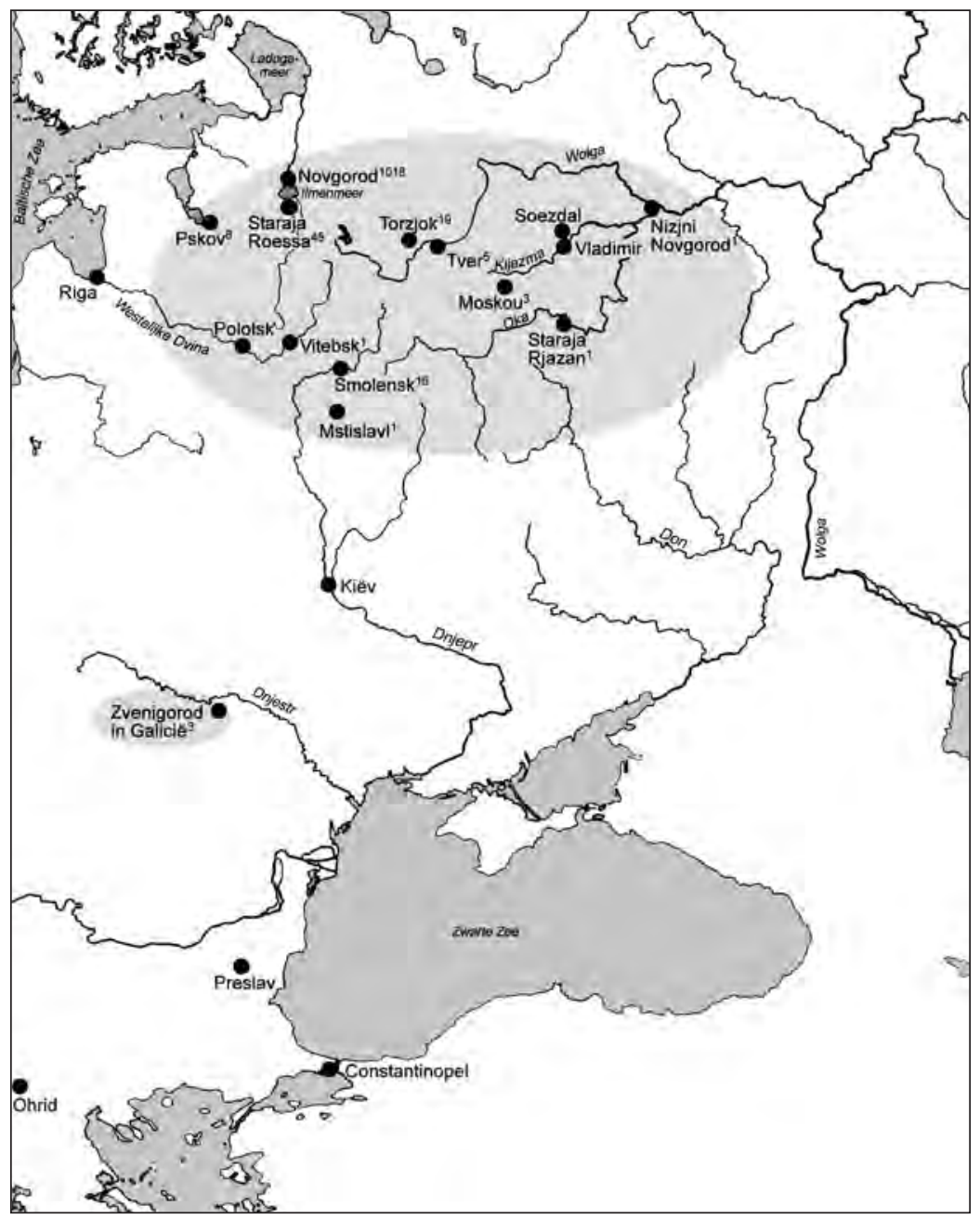

Verspreidingsgebied van vondsten van berkenbastteksten (vanaf 1951 tot en met 2011)

We moeten ons eerst realiseren dat wanneer er niet gegraven wordt, er ook niks gevonden kan worden. Systematische opgravingen van enige omvang vinden alleen plaats in Novgorod. In andere steden, zoals in Staraja Roessa, Torzjok en Smolensk, zijn de 
archeologische expedities veel kleinschaliger en is de kans op vondsten per definitie kleiner. In weer andere plaatsen zijn berkenbastteksten min of meer toevallig ontdekt, zoals de enige uit Vitebsk (gevonden bij grondwerkzaamheden in 1959) en de laatste twee uit Moskou (opgegraven in 2007 bij het Kremlin). De variëteit in de diverse opgravingen is dus groot en we weten niet wat er nog allemaal in de grond zit. Van sommige historische plaatsen, bijvoorbeeld van Pskov en Smolensk, verwachten we beslist meer dan wat tot nu toe is gevonden. Volgens berekeningen van de Russische archeoloog en historicus Valentin L. Janin moeten er alleen al in Novgorod maar liefst twintigduizend berkenbastteksten in de grond bewaard zijn; minder dan drie procent van de oppervlakte van de middeleeuwse stad is tot nu toe onderzocht.

Een verdere archeologische omstandigheid die bepalend is voor het vaststellen van de omvang en het verspreidingsgebied van de schrijfcultuur op berkenbast, is de bodemgesteldheid. Alleen onder de juiste condities kan organisch materiaal, dus ook berkenbast, goed geconserveerd blijven. De zuurstofarme compacte kleigrond in Novgorod is daarvoor ideaal. Op zes tot meer dan acht meter diepte vinden we organische en niet-organische resten van de middeleeuwse cultuur, reikend tot de eerste helft van de tiende eeuw; spullen van hout, bot, leer en textiel, en daarnaast ook aardewerk, glas, barnsteen, ijzer, brons en andere metalen. De archeologische opgravingen, die al vanaf het begin van de jaren dertig van de vorige eeuw systematisch in Novgorod plaatsvinden, hebben een schat aan voorwerpen opgeleverd: loden zegels, houtsnijwerk, kammen van bot, ijzeren scharen, leren schoenen en maskers, mandjes van berkenbast, sieraden, speelgoed, muziekinstrumenten, enz.

Ondanks het feit dat nagenoeg alle vondsten van berkenbastteksten uit Novgorod komen, is er geen reden om aan te nemen dat we met een exclusieve lokale Novgorodse schrijfcultuur te maken hebben. Zoals gezegd, niet overal vinden omvangrijke opgravingen plaats in de politieke en culturele centra van middeleeuws Rusland, en niet overal zijn de archeologische condities zo goed als in Nov- 
gorod. De gewoonte om te communiceren via berkenbastbrieven moet zonder meer bekend geweest zijn buiten Novgorod. Immers, de in Novgorod opgegraven brieven werden gewoonlijk van buiten de stad gestuurd. Zeker in de vroegere periode gebeurde dat geregeld over grotere afstanden, zoals in het geval van brief nr. 424 uit Novgorod, waarin Gjoergi zijn ouders vraagt om 'hierheen - naar Smolensk of naar Kiëv' te komen (zie p. 47), of nr. 745, gestuurd naar Novgorod door 'Pavel uit Rostov' (p. 144).

Ook hebben we brieven van mensen die niet uit Novgorod kwamen. Zo weten we van een van de oudste berkenbastbrieven, nr. 246 (p. 58), dat de afzender geen Novgoroder kan zijn geweest en dat hij waarschijnlijk uit Smolensk, Vitebsk of Polotsk kwam. In het geval van een van de brieven die in Tver is opgegraven, Tver nr. 2 (ca. 1300-1320), hebben we te maken met correspondentie op berkenbast buiten Novgorod om, d.w.z. tussen de nabijgelegen steden Torzjok en Tver: Groet van Grigori aan moeder. Kom snel naar me toe, naar Torzjok. Maak je spullen op orde en reis naar Torzjok ...

Verder zijn er nogal wat brieven die van buitenaf naar Novgorod zijn gestuurd en waarin expliciet om een antwoord wordt gevraagd. In de zojuist genoemde brief nr. 424 van Gjoergi aan zijn ouders vraagt hij op het eind: 'Als jullie niet komen, stuur me dan een briefje'. In nr. 358 (p. 148) instrueert Ontsifor, die duidelijk buiten de stad is, zijn ondergeschikte Nester 'een brief over de helm' te sturen. Ook Mestjata in nr. 422 (p. 137) is buiten de stad en schrijft: 'Als jullie iets nodig hebben, stuur dan iemand naar me en geef hem een brief mee'. Als al deze antwoorden verstuurd, bewaard en opgegraven zouden zijn in plaatsen buiten Novgorod, zou het verspreidingsgebied van de schrijfcultuur op berkenbast er veel diverser hebben uitgezien dan op de kaart op p. 20.

Dat schrijven op berkenbast in de Middeleeuwen geen ongewone zaak was, weten we ook uit historische bronnen. Russische geschiedschrijvers en etnografen hebben al vanaf de vijftiende eeuw rechtstreeks verslag gedaan van het gebruik van berkenbast als schrijfmateriaal. In musea en archieven zijn latere documenten op 
berkenbast bewaard, zoals bijvoorbeeld een berkenbastboek uit Siberie uit het begin van de achttiende eeuw, waarin de tribuut voor de tsaar werd bijgehouden. In het midden van de negentiende eeuw is nog melding gemaakt van het gebruik bij de Oudgelovigen.

Buiten Rusland vinden we ook getuigenissen van het schrijven op berkenbast. De belangrijkste is die van de Zweedse geschiedschrijver Olaus Magnus in zijn Historia de gentibus septentrionalibus (1555; vertaald in 1652 in Amsterdam onder de titel Toonneel der Noordsche Landen) over het gebruik in Scandinavië:

... ooit stuurden de mensen van het Noorden elkaar brieven ingekrast in hout, aangezien dit de bekendste vorm van schrijfmateriaal was. Inderdaad, zelfs nu, wanneer papier op raakt in militaire kampen of belegerde steden, gebruiken ze voor hun brieven de bast of hout van een berkenboom, gesneden in reepjes of eerder in dunne vellen.

Direct bewijs van deze observatie bevindt zich onder andere in het Zuidzweedse Vadstena-klooster, waar in een papieren handschrift uit de tweede helft van de vijftiende eeuw een korte Latijnse notitie op berkenbast, geschreven in inkt, bewaard is gebleven. Een verder bewijs uit een geheel andere hoek maakt onderdeel uit van het corpus berkenbastteksten, namelijk nr. 11 uit Smolensk, met daarop Scandinavische runen uit het midden van de twaalfde eeuw (zie p. 127).

Als we verder teruggaan in de tijd, dan vinden we al bij de Romeinen vermeldingen van schrijven op basten van bomen. Plinius de Oudere schrijft in zijn Naturalis Historia dat voor de opkomst van papyrus "de bast van bepaalde bomen" gebruikt werd om op te schrijven. Bast als schrijfmateriaal herkennen we ook in het Latijnse woord liber dat zowel 'boek' als 'bast' betekent (en dat overigens verwant is met het Russische woord voor bast, loeb). Hout in het algemeen om op te schrijven vinden we terug in de etymologische relatie tussen beuk en boek (oorspronkelijk 'schrijftafeltje van beukenhout'). 


\section{Datering en periodisering}

Zoals te zien is in dit boek, hebben verreweg de meeste berkenbastteksten een behoorlijk nauwkeurige datering: '1100-1120', '12401260', '1380-1400', enz. Meestal gaat het om intervallen van twintig jaar waarbinnen ze gedateerd kunnen worden. Deze gelukkige omstandigheid is te danken aan betrouwbare archeologische gegevens. Daarbij gaat het met name om een combinatie van stratigrafische en dendrochronologische dateringsmethoden: de specifieke bodemlaag waarin berkenbasten worden opgegraven en de absolute data die daaraan verbonden kunnen worden op basis van de patronen van jaarringen in het hout dat zich ook in die bodemlaag bevindt. Dat hout is voornamelijk afkomstig van de knuppelpaden die door de stad liepen en die geregeld opnieuw gelegd moesten worden - de een over de ander - vanwege de aanzwellende cultuurlaag (ongeveer een centimeter per jaar gedurende de Middeleeuwen), d.w.z. alle soorten overblijfselen van menselijke activiteiten. Onder maximaal gunstige archeologische omstandigheden kunnen berkenbastteksten op deze manier gedateerd worden met een precisie van tien tot vijftien jaar. Dit is in het bijzonder het geval bij de twee grootste en meest systematische opgravingen in Novgorod, de Nerev-opgraving (actief van 1951 tot 1962), ten noorden van het kremlin, en de Troitski (nog steeds actief sinds 1973), ten zuiden ervan, in de Ljoedin wijk (zie de kaart op p. 16). Beide opgravingen zijn goed voor meer dan tachtig procent van alle vondsten in Novgorod en komen enigszins met elkaar overeen wat betreft omvang, archeologische diepte en aantallen opgegraven berkenbastteksten.

In sommige gevallen kan de datering nog nauwkeuriger, namelijk wanneer we aanvullende kennis hebben uit andere bronnen (met name de kronieken) van historische gebeurtenissen of personen (zie nr. 963, p. 116, en nr. 286, p. 117). In andere gevallen zijn de archeologische omstandigheden waaronder de teksten zijn gevonden minder goed, bijvoorbeeld wanneer het om een toevallige vondst gaat, en zijn er aanvullende dateringsmethoden nodig, 
met name van paleografische en taalkundige aard. We zien immers dat in de loop van de tijd de Oudnovgorodse taal langzamerhand verandert en dat ook het handschrift en de orthografie zich ontwikkelen.

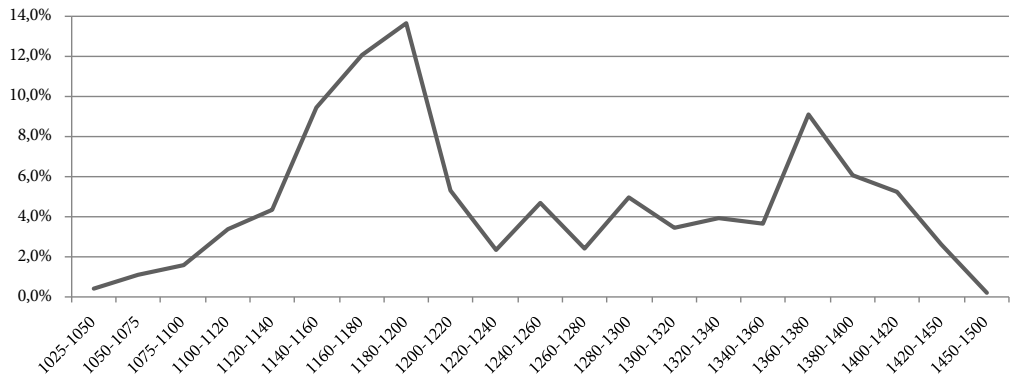

Chronologie van vondsten van berkenbastteksten

Als we kijken naar de grafiek hierboven waarin het chronologisch verloop van vondsten van berkenbastteksten is weergegeven, dan valt meteen de piek op rond het jaar 1200. Bijna de helft van de opgegraven teksten stamt uit de periode voor het begin van de dertiende eeuw: het aantal vondsten neemt vanaf de vroegste periode langzaam toe, stijgt snel in de tweede helft van de twaalfde eeuw, maar stort vervolgens abrupt in elkaar na de wisseling naar de dertiende eeuw. Natuurlijk kunnen we niet met zekerheid vaststellen of de vondsten representatief zijn voor de daadwerkelijke productie van berkenbastteksten en het verloop door de eeuwen heen. Het aantal vondsten is echter inmiddels significant en bevestigt het algemene patroon dat al vijfentwintig jaar geleden is vastgesteld, toen er nog maar zevenhonderd teksten waren opgegraven. Destijds werd de 'epistolaire crisis' in de dertiende eeuw verbonden met een verwoestende hongersnood in 1230 en vooral met de Tataarse invasie in 1237-1242. De stad Novgorod werd weliswaar niet ingenomen, maar de rest van Rusland, waaronder Kiëv, werd wel onderworpen. Hierdoor stagneerde ook de Novgorodse economie omdat internationale handelswegen werden afgesneden. Communicatie via ber- 
kenbastbrieven hing samen met mobiliteit; van het internationale handelsverkeer - tussen de Oost-Slavische vorstendommen en nog verder weg - en de grote actieradius die we kunnen waarnemen in brieven uit de periode voor de crisis, zoals bijvoorbeeld in de nieuwste vondsten uit de tweede helft van de twaalfde eeuw (zie het commentaar bij nr. 1000, p. 52), zien we in latere eeuwen nauwelijks iets terug. Wanneer in vondsten van recentere datum plaatsen buiten de stad vermeld worden, dan bevinden die zich grotendeels binnen het inmiddels naar het noorden en noordoosten uitgedijde Novgorodse territorium.

Hoewel het 'Tataarse juk' vanaf het midden van de dertiende eeuw zonder twijfel de belangrijkste reden moet zijn geweest waarom de productie van berkenbastteksten nooit meer steeg tot het niveau in de periode daarvoor, zien we dat de 'epistolaire crisis' al eerder heeft ingezet, namelijk vlak na 1200 . Wat is er toen gebeurd? Uit de kronieken weten we van een interne machtsstrijd in Novgorod in 1207. Hierbij dolven de bojaren (edelmannen) van de Ljoedin wijk het onderspit; ze verloren hun bezittingen, werden uit de stad verjaagd en hun huizen werden verbrand. Het is precies in de Troitskiopgraving die zich in de Ljoedin wijk bevindt, waar we in die periode de scherpe neergang in berkenbastvondsten aantreffen.

Er was nog meer aan de hand in die tijd: er waren oorlogsdreigingen aan de westelijke grens van Novgorod, door de Duitse Zwaardbroeders die zich in de Baltische regio hadden gevestigd, en aan de noordwestelijke grens, van de zijde van de Zweden. Bovendien werd Constantinopel in 1204 ingenomen en ontstond er een instabiele situatie in de Bosporus, met handelsrestricties die ook de Novgoroders troffen. Interne, maar ook externe problemen zorgden er dus voor dat de stagnatie in communicatie via berkenbastteksten al aan het begin van de dertiende eeuw intrad.

In de loop van de veertiende eeuw stijgt het aantal gevonden berkenbastteksten weer langzaam en treffen we vaak brieven aan die te maken hebben met het beheer van grootgrondbezit buiten de stad (zie in het bijzonder de sectie Heren en boeren, p. 72 e.v.). Maar 
in de eeuw daarna daalt het aantal teksten snel; uit de laatste periode van overlevering stamt nog maar een handjevol (zie nr. 495, p. 51). Dat er na die tijd niets meer is gevonden heeft in eerste instantie te maken met het feit dat in de zeventiende en achttiende eeuw drainagesystemen in de stad zijn aangelegd waardoor al het organisch materiaal in de bodem vanaf de zestiende eeuw verloren is gegaan. Stel dat dat niet gebeurd zou zijn? Hadden we dan wel berkenbastteksten uit jongere perioden aangetroffen? De kans is klein. Het aantal vondsten droogt al op in de tweede helft van de vijftiende eeuw en deze neergang valt precies samen met de periode waarin Novgorod zijn politieke en economische macht verliest, en uiteindelijk zelfs zijn onafhankelijkheid door de annexatie in 1478 door Moskou. In een breder perspectief moet ook de wijdere verspreiding van papier in Rusland vanaf het midden van de vijftiende eeuw een rol hebben gespeeld bij de teloorgang van de schrijftraditie op berkenbast.

Terwijl het eind van de schrijftraditie goed te beredeneren valt, is het moeilijker om de vraag te beantwoorden hoe deze eigenlijk tot stand is gekomen. Daarvoor moeten we terug naar de vroegste gegevens over de verschriftelijking van middeleeuws Rusland. De oudste berkenbastteksten stammen uit het tweede kwart van de elfde eeuw: een alfabetoefening (nr. 591 uit ca. 1030, p. 105), een iconografische voorstelling met inscripties (nr. 915-I uit ca. 1030, p. 111) en twee brieven (nr. 246, p. 58, en nr. 247, p. 54). Uit nog oudere bodemlagen zijn geen teksten tevoorschijn gekomen. Andere betrouwbaar gedateerde getuigenissen van het gebruik van het cyrillisch schrift in Rusland zijn niet veel ouder en komen uit de eerste twee decennia van de elfde eeuw, dus vlak na de kersteningsdatum 988, wanneer grootvorst Vladimir I wordt gedoopt. Daarbij gaat het om munten van voor 1019 met inscripties erop van Vladimir I en van zijn zonen Svjatopolk en Jaroslav (de Wijze). Van de laatste is ook een zegel gevonden. De belangrijkste vondst uit deze vroegste periode is echter de Novgorodse Codex, bestaande uit drie houten wastafeltjes met daarop psalmteksten (zie p. 103). 
Bekijken we al het betrouwbaar gedateerde materiaal, dan moeten we vaststellen dat systematisch gebruik van het cyrillisch schrift kort na de kerstening inzet. Dit is niet verwonderlijk, want de kerstening bracht de noodzaak met zich mee om bijbelse en liturgische teksten te verspreiden en hiervoor ook mensen op te leiden die konden lezen en schrijven. Toegespitst op de situatie in Novgorod blijkt een opmerking uit het jaar 1030 in de zogenaamde NovgorodSofia groep van Russische kronieken heel goed samen te vallen met de eerste getuigenissen van de schrijftraditie op berkenbast. In dat jaar kwam grootvorst Jaroslav de Wijze, nadat hij de Finse Tsjoeden heeft verslagen, naar Novgorod "en verzamelde 300 kinderen van de oudsten en priesters om hen de boeken te onderwijzen. En de aartsbisschop Ioakim stierf en zijn leerling was Efrem, die ons onderwees". Met Jaroslavs instructie wordt ongetwijfeld een christelijke opvoeding in het algemeen bedoeld, maar ook onderwijs in praktische zin - leren lezen en schrijven - moet daar deel van uitgemaakt hebben.

Hiermee was de voedingsbodem geschapen voor verdere verschriftelijking, zowel op perkament als op berkenbast. Het ene (dure) materiaal werd gebruikt voor het religieuze en openbare domein (liturgische teksten, oorkonden, verdragen), het andere (gratis) voor het seculiere, private en pragmatische. De oorsprong van de schrijftraditie op berkenbast moet, in de woorden van de Russische filoloog Aleksej A. Gippius, gezien worden als een "spontaan bijproduct van de verspreiding van het christelijk onderwijs". We zien ook dat de twee oudste berkenbastteksten ten nauwste samenhangen met het onderwijs en het religieuze milieu: de zojuist genoemde alfabetoefening (nr. 591) en de iconografische voorstelling (nr. 915-I). De band tussen kerk en samenleving vinden we vaker terug in berkenbastteksten uit de vroegere periode, zelfs in de twee oudste brieven die hierboven ook al genoemd zijn: in nr. 246 gaat het over het 'Heilige Hout' (zie verder p. 58) en in nr. 247 komt de bisschop ter sprake die is ingeschakeld bij een juridisch conflict (p. 54). 


\section{Schrijftechniek en praktijk}

Er is weinig tot niets voor nodig om een stuk berkenbast klaar te maken om op te schrijven. Omdat nogal wat opgegraven berkenbasten met tekst erop er glad en elastisch uitzien (meestal in opgerolde vorm), wordt vermoed dat ze eerst geweekt werden in heet water. Voordeel van berkenbast is dat ze uit dunne laagjes bestaat die afgepeld kunnen worden wanneer ze te ruw zijn. Dit geeft trouwens als handige bijkomstigheid de mogelijkheid om een 'kopie' te bewaren wanneer de tekst is doorgedrukt in de onderlaag, zoals wellicht het geval is bij brief nr. 344 (p. 48) en nr. 736 (p. 49).

Om te schrijven werd een scherpe schrijfstift (stylus) van metaal of bot gebruikt waarmee letters in de bast werden ingekrast. Er zijn slechts drie berkenbastteksten in inkt overgeleverd, alle drie uit de allerlaatste fase van de schrijftraditie (midden of tweede helft van de vijftiende eeuw). Gewoonlijk werd op de zachtere binnenkant van de bast geschreven, hoewel men nogal pragmatisch omging met het materiaal; soms werd toch alleen de buitenkant gebruikt (bijvoorbeeld bij nr. 907, p. 59, hoewel de schrijver blijkbaar heeft zitten aarzelen) of werden beide kanten beschreven (vergelijk nr. 724, p. 122, en nr. 354, p. 149; de eerste begint op de buitenkant, de tweede op de binnenkant).

De afmetingen van een volledige berkenbasttekst kunnen sterk variëren. Zo zijn bijvoorbeeld nr. 79 (p. 142) en nr. 397 (p. 145) niet groter dan $6 \times 1,5 \mathrm{~cm}$. resp. 4,6 $x 2,6 \mathrm{~cm}$., terwijl het eerste stuk berkenbast waarop Moisej zijn testament schreef (nr. 519, p. 70) bijna een halve meter breed is. De verhoudingen tussen breedte en hoogte schommelen tussen 2:1 en 15:1,
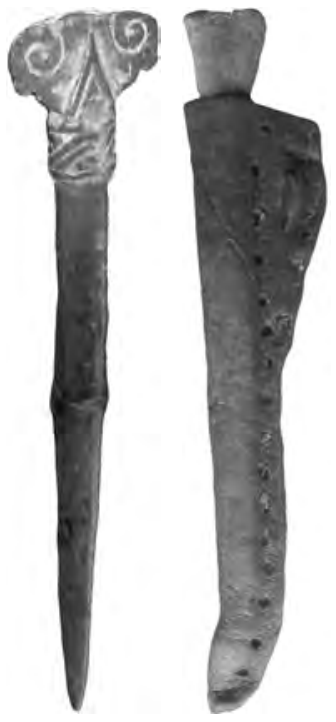

Twee schrijfstiften uit Novgorod; de linker is van metaal, de rechter is van bot en zit in een leren holster 
met uitschieters als brief nr. 358 (p. 148), die bijna veertig centimeter breed is, maar slechts tweeënhalf hoog. Meestal werd de berkenbast bijgesneden nadat de tekst erop was gezet, hoewel we enkele gevallen hebben waarbij dat om onduidelijke redenen niet is gebeurd (zie bijvoorbeeld nr. 421, p. 64).

De tekstomvang van volledig bewaarde documenten is in de regel niet groot. De meeste zijn niet langer dan twintig woorden, een beperkt aantal is langer dan vijftig, en de langste die op één stuk berkenbast is geschreven (op beide kanten) beslaat met 166 woorden ongeveer een half A4-tje (nr. 531, p. 98).

De selectie berkenbastteksten in dit boek geeft wellicht de indruk dat de meeste brieven volledig bewaard gebleven zijn. Dat is echter slechts in een kwart van de gevallen zo. De meeste hebben kleinere of grotere lacunes, zelfs zo groot dat er maar een snippertje met een paar letters of woorden van is overgebleven. Als voor-

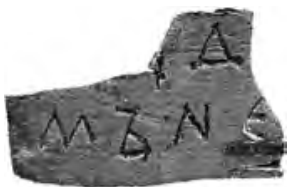

beeld is hier Novgorod nr. 29 (ca. 1400-1410) afgebeeld, met slechts vijf letters waarvan de onderste vier misschien het voornaamwoord 'mij' vormen. Natuurlijk kunnen deze overblijfselen simpelweg het resultaat zijn van de tand des tijds. Maar vaak zijn de overgebleven resten het werk van mensenhanden, d.w.z. ze werden na lezing verscheurd of kapotgesneden (zie nr. 752, p. 87). In andere gevallen werden brieven geanonimiseerd door de aanhef, met daarin de namen van afzender en geadresseerde, eraf te scheuren (zie nr. 155, p. 56, waar ook nr. 881 wordt aangehaald, waarin expliciet gevraagd wordt aan de ontvanger om de brief 'in reepjes' te scheuren).

Het kan zijn dat berkenbastteksten soms niet meteen na lezing weggegooid - al dan niet verscheurd - werden, maar nog een tijdje bewaard werden. Dit zou vooral goed gekund hebben in het geval van individuele lijstjes van goederen, uitgaven of schulden die nog verder afgehandeld moesten worden (zie nr. 722, p. 42, nr. 926, p. 43, en nr. 495, p. 51), of van andersoortige notities voor persoonlijk gebruik (zie bijvoorbeeld het 'berkenbastboekje', nr. 419, 
p. 112). Systematische verzamelingen of zelfs archieven zijn tot nu toe echter niet gevonden en het is ook niet erg aannemelijk dat die er ooit geweest zijn. De schrijfcultuur op berkenbast was wat wel eens 'throw-away literacy' genoemd wordt: de briefjes werden weggegooid zodra de business deal was afgerond, het persoonlijke bericht was overgebracht, of de kladversie van een belangrijk document was overgeschreven op perkament. Die laatste gewoonte komt expliciet ter sprake in Novgorod nr. 831 (ca. 1140-1160), een document dat gaat over een serieus conflict en dat eindigt met de instructie: En jij, Stepan, schrijf dit over op perkament en stuur het weg (zie verder ook nr. 519/520, p. 70). Zoals de Britse historicus Simon Franklin het verwoordt in zijn boek Writing, Society and Culture in Early Rus: "Scribes of parchment manuscripts kept half an eye on eternity; senders of birch-bark letters would hardly have counted on the prying persistence of future archaeologists". Om een parallel te trekken met hedendaagse communicatiemiddelen: we zouden ook verbaasd zijn wanneer onze dagelijkse stroom e-mailtjes, sms'jes of tweets over duizend jaar tevoorschijn zou komen.

Hoe werd een berkenbastbrief overgebracht? We hebben geen aanwijzingen voor een geregeld of zelfs geïnstitutionaliseerd postsysteem. De koerier van de brief komt herhaaldelijk ter sprake in brieven (zie de inleiding op het deel Communicatie, p. 131, en de aparte sectie De rol van de koerier, p. 138 e.v.) en het lijkt erop dat het vaak ging om personen die bewust uit de eigen kring gestuurd werden (familieleden, ondergeschikten, afgevaardigden van een collectief boeren of dorpsbewoners). Maar ongetwijfeld werden brieven ook meegegeven aan mensen die toevallig toch al naar de plaats van bestemming gingen. In bepaalde gevallen moet de vertrouwelijkheid van de boodschap een punt van aandacht zijn geweest bij de overdracht, zoals in het bericht van het 'front', nr. 636 (p. 121), waar noch de afzender, noch de geadresseerde genoemd wordt. In Novgorod nr. 24 (ca. 1400-1410) komt het punt zelfs expliciet aan de orde. Van het fragment is alleen het eind van de laatste zin bewaard gebleven: ... met ... man stuur een briefje in het ge- 
heim. Deze 'man' moet niet een of andere willekeurige koerier zijn geweest, maar een vertrouweling van de correspondenten.

\section{Gebruikers en geletterdheid}

Wie waren de mensen die communiceerden via berkenbastteksten? En: waren afzender en geadresseerde tegelijkertijd ook schrijver en lezer? Aanvankelijk, in de periode van de eerste ontdekkingen, bestond de indruk dat geletterdheid wijdverspreid was in Novgorod; het 'gewone volk' was in groten getale 'alfabeet'. Dit was een populaire gedachte in de voormalige Sovjet-Unie. De zaak ligt echter subtieler. Nu er veel meer materiaal bij is gekomen, beginnen we een redelijk goed beeld te krijgen van de 'doorsnee berkenbastgebruiker'. Met name de uitgebreide sociale netwerken die tegenwoordig gereconstrueerd kunnen worden en waarin vaak belangrijke personen figureren die we ook uit de kronieken kennen (zie p. 160 e.v.) laten zien dat we vooral te maken hebben met de Novgorodse elite: mannen met geld en macht, en ook mannen die rechtstreeks met deze bovenlaag in contact stonden en hiermee of hiervoor zaken deden. Als we bedragen tegenkomen, dan gaat het meestal om groot geld; als er een conflict is, dan staat er meestal veel op het spel.

Dit algemene beeld behoeft echter een aantal nuances. Het ging beslist niet altijd om correspondentie of administratie van 'seculiere rijke mannen'. Ook geestelijken schreven op berkenbast, zoals Efrem die teleurgesteld is in zijn medebroeder Isoechija (nr. 605, p. 107), en ook arme dorpelingen vonden hun weg via berkenbast en stylus om een noodkreet bij hun heer te uiten omdat er niets meer is 'om te zaaien en ook niets om te eten' (nr. 361, p. 78). Bovenal: er zijn tientallen berkenbastbrieven die van vrouwen afkomstig zijn en/of gericht aan vrouwen. In dit boek zijn er meer dan twintig opgenomen: Boris schrijft aan zijn vrouw Nastasja over zijn drukke werkzaamheden buiten de stad (nr. 43, p. 85) en Nastasja schrijft aan haar familie over de dood van Boris en hoe het nu ver- 
der moet gaan (nr. 49, p. 86); een vrouw schrijft een man waarom hij verstek heeft laten gaan bij een afspraakje (nr. 752, p. 87); de koppelaarster Miloesja informeert de moeder van de bruid over een pas afgesloten huwelijksovereenkomst (nr. 955, p. 90); Nezj$\mathrm{ka}$ is kwaad op haar broer omdat hij de twee geleverde ringen nog steeds niet heeft laten omsmeden (nr. 644, p. 94); Gostjata vraagt een familielid om naar haar toe te komen omdat haar man er vandoor is gegaan met 'een nieuwe vrouw' en de bruidsschat niet wil teruggeven (nr. 9, p. 95); Ana roept de hulp in van haar broer in een hoog oplopend conflict waarbij zij een hoer is genoemd en haar dochter een slet (nr. 531, p. 98).

Dit zijn slechts enkele voorbeelden van afwijkingen op het algemene profiel van de 'doorsnee berkenbastgebruiker'. De afwijkingen zijn illustratief voor de integratie van de schrijfcultuur op berkenbast in de Novgorodse samenleving. Als je toegang had tot die schrijfcultuur en je had iets belangrijks te melden, dan maakte het in principe niet uit wie je was. Schrijven op berkenbast was een puur pragmatische aangelegenheid.

Maar wie had er eigenlijk direct toegang tot die schrijfcultuur? Wie kon zelf lezen en schrijven? Deze vraag is niet eenvoudig te beantwoorden, al was het maar omdat er verschillende graden van geletterdheid zijn en omdat helemaal niet duidelijk is wat het betekent wanneer om paleografische of andere redenen is vastgesteld dat een afzender zijn brief niet zelf heeft geschreven. Neem bijvoorbeeld Petr, die een belangrijke bestuurder en bojaar was (zie p. 162): al zijn brieven zijn in een verschillend handschrift. Was hij minder geletterd dan bijvoorbeeld Grigori (p. 164), die zijn brieven en notities wel zelf geschreven moet hebben? Gezien Petrs maatschappelijke positie is het veel waarschijnlijker dat hij zijn post uitbesteedde door brieven te dicteren. Ook wanneer we goede gronden hebben om aan te nemen dat de koerier degene was die een brief had geschreven of een brief voorlas, zegt dat in principe nog niets over de geletterdheid van de correspondenten. Het is bijvoorbeeld erg aannemelijk dat brief nr. 422 (p. 137) door de koerier is geschre- 
ven in naam van Mestjata en is voorgelezen aan de geadresseerden Gavsja en Sdila. Van nr. 497 (p. 147) weten we zeker dat het de koerier moet zijn geweest die Gavrila's uitnodiging heeft opgeschreven en dat hij ook zorg heeft gedragen voor de schriftelijke respons van diens zwager en zus. Desalniettemin blijft het goed mogelijk dat Mestjata en Gavrila zelf konden schrijven en dat de geadresseerden hun brieven konden lezen. Dat men wel geletterd kon zijn, maar niet altijd zelf schreef, zien we bij Moisej van wie persoonlijke notities van eigen hand zijn overgeleverd (nr. 521, p. 71), maar ook een voorversie van zijn testament: 'Hierbij schrijf ik, Gods dienaar Moisej, mijn testament bij leven' (nr. 519/520, p. 70). Die kladversie heeft hij niet zelf geschreven omdat het handschrift niet overeenkomt met dat van zijn eigen aantekeningen.

In principe hebben we geen bewijs dat er op grote schaal gebruik werd gemaakt van professionele schrijvers en dat geletterdheid in Novgorod dus een beperkt verschijnsel was. Bij brieven die van buiten de stad werden opgestuurd en die uit korte, eenvoudige mededelingen bestaan, ligt dat ook om praktische redenen niet erg voor de hand. Wanneer Kyas en Zjirotsjko een simpel briefje schrijven aan Tverdjata en Ivan in Novgorod, met als enige mededeling dat het goed met hen gaat (nr. 1000, p. 52), dan mogen we veronderstellen dat de briefschrijver of Kyas of Zjirotsjko was. Ook bij vertrouwelijke of hoogst persoonlijke communicatie is de inbreng van een professionele schrijver niet of nauwelijks aannemelijk, zoals bijvoorbeeld in het geval van de anonieme 'liefdesbrief' nr. 752 (p. 87) of Ana's emotionele roep om hulp (nr. 531, p. 98).

Uiteraard moeten er brieven zijn geweest die wel zijn uitbesteed omdat de afzender niet geletterd was. In eerste instantie denken we dan aan de brieven van boeren en dorpen die als collectief hun heren aanschrijven. Daarbij laat de graad van professionaliteit van de schrijver af en toe wel te wensen over (zie nr. 307, p. 80). Ook in het geval van nr. 9 hebben we aanwijzingen dat de afzender Gostjata gebruik heeft gemaakt van een professionele schrijver (p. 95). Of neem de vroege teksten Novgorod nr. 912 en nr. 913 
(beide ca. 1050-1075). De eerste luidt: Brief van Ljoedslav aan Choten. Stuur me het geld. Zelfs als je Sven hier niet naar toe laat gaan, stuur het. Het mooie gekalligrafeerde handschrift, dat we eerder in perkamenten boeken zouden verwachten, geeft al enige twijfel over het auteurschap van Ljoedslav. Die twijfel wordt versterkt door nr. 913: een lijstje van kerkelijke feestdagen geschreven in precies hetzelfde mooie handschrift als nr. 912. Ljoedslav is een heidense (Slavische) naam, net zoals overigens Choten die we in nr. 902 (p. 68) tegenkomen als belastinginner (Sven is uiteraard Scandinavisch). Het is niet erg waarschijnlijk dat deze Ljoedslav de geoefende schrijver is van zowel het briefje als het liturgische lijstje. Het ligt veel meer voor de hand om aan te nemen dat Ljoedslav niet in staat was om het briefje zelf te schrijven en de hulp heeft ingeroepen van een geestelijke: de clerus trad in dit geval dus op als de klerk, zoals in het meest recente commentaar op de twee teksten treffend is opgemerkt. Deze praktijk moet in ieder geval voor de oudere fase van de schrijftraditie op berkenbast niet ongewoon zijn geweest.

We kunnen concluderen dat communicatie en administratie via berkenbastteksten in principe voor iedereen toegankelijk was, maar dat deze voornamelijk werd gebruikt door de hogere lagen van de bevolking. Simpelweg omdat er voor deze sociale groep meer viel te communiceren, met name over een grotere geografische afstand, of te administreren, zoals schulden om te innen of te voldoen.

Zelf schrijven en lezen was niet ongewoon en wellicht eerder praktijk dan uitzondering. Daarop wijzen ook de honderden schrijfstiften die in Novgorod zijn opgegraven en de getuigenissen die we vanaf de vroegste periode hebben van het leerproces (zie p. 101 e.v.): de schrijfoefeningen van Onfim en alfabetoefeningen van anderen op berkenbast, wastafeltjes die voor hetzelfde doel gebruikt werden, en brief nr. 687 (p. 106) die zo duidelijk maakt dat leren lezen en schrijven geen uitzonderlijke bezigheid was. 


\section{Taal en communicatie}

De tweede regel van nr. 247 (zie p. 54), opgegraven in 1956, luidt in wetenschappelijke transcriptie als volgt:

\section{azamøkekěleadvorikělěagospodarbvonetjažěneděe}

In de eerste Academie-uitgave van deze tekst, in 1963, gaf deze regel de nodige hoofdbrekens. Dat er geen woordscheidingen zijn, is gebruikelijk voor middeleeuwse teksten, maar het helpt natuurlijk niet wanneer woorden en grammaticale uitgangen onduidelijk zijn. Uiteindelijk maakte men er in 1963 het volgende van:

A zamıke kělea, dvıri kělěa. A gospodarı vo netjažě, neděe.

Deze lezing leverde de volgende onsamenhangende vertaling op, inclusief grammaticale ongerijmdheden in de interpretatie: 'En het slot van de (klooster)cel, de deuren van de cel. En de eigenaar is lui, doet niets'. Pas in de jaren tachtig, toen het onderzoek naar de taal van berkenbastteksten op een hoger niveau terecht was gekomen, is duidelijk geworden hoe de regel in nr. 247 echt gelezen moet worden. Hetzelfde geldt voor vele andere stukken tekst die eerder volstrekt duister waren. Inclusief een verdere correctie in de editie van 1993 luidt de regel:

A zamıke kěle a dvbri kělè. A gospodarb vo ne tjažě ne děe. Hier staat iets heel anders: 'En het slot is heel en de deuren zijn heel, en de eigenaar doet daarom geen aanklacht'. In combinatie met het vervolg van de tekst bleek nr. 247 een coherent verslag te zijn van een juridisch onderzoek. Cruciaal voor deze nieuwe interpretatie was het inzicht dat in de Oudnovgorodse taal een eeuwenoude Slavische klankwet niet had plaatsgevonden. Dit maakte duidelijk dat we niet te maken hebben met het substantief 'kloostercel', maar met het adjectief 'heel' (in de stam kèl-herkennen we het Nederlandse woord). Ook de onverwachte uitgangen -e en -ě (in zamøke 'slot', en kěle/kělě) bleken systematische Oudnovgorodse eigenaardigheden te zijn; het eerste stuk van de zin was grammaticaal goed te be- 
redeneren. Een verdere analyse van het tweede stuk bracht aan het licht dat de aanvankelijke woordscheiding onjuist was en dat we te maken hadden met een specifieke voorzetselconstructie ('daarom') gevolgd door het woord voor 'aanklacht, proces'; er was geen sprake van een 'luie' eigenaar!

De Oudnovgorodse taal op berkenbast bleek in fundamenteel opzicht af te wijken van de taal die men kende uit de vele middeleeuwse perkamenten handschriften: die waren grotendeels geschreven in het Kerkslavisch, een taal waarvan de basis ligt in het Bulgaars van de negende eeuw en die sinds de aanname van het christendom in Rusland in een enigszins gerussificeerde vorm eeuwenlang is gebruikt in de kerk en andere instituties. Het van oorsprong uitheemse en functioneel beperkte Kerkslavisch geeft weinig inzicht in de daadwerkelijke taalvariëteit in middeleeuws Rusland. Van die variëteit is het Oudnovgorods de meest opvallende representant. Gelegen in de periferie van het Slavische taalgebied en onder invloed van andere talen, Baltische en Oostzeefinse, is het al vroeg zijn eigen weg gegaan. We zien op het terrein van de fonologie (klankleer) en grammatica bijzondere verschijnselen die we elders in het Russisch en Slavisch niet aantreffen.

Inmiddels is de grammatica van het Oudnovgorods goed in kaart gebracht en verbazen we ons niet meer over die $k$-in het woord voor 'heel' in nr. 247, ook al treffen we het elders in het Slavisch aan met een $t s$ aan het begin. We zijn ook vertrouwd met de vaak voorkomende spellingeigenaardigheid om verschillende klinkertekens voor een en dezelfde klank te gebruiken. In eerste instantie interpreteerde men deze variatie in spelling als chaos en een teken van beperkte geletterdheid. Nu weten we dat ze langs systematische lijnen verloopt en dat we met een alternatief systeem voor het spellen van bepaalde klinkers te maken hebben. Zo kan het gebeuren dat we het woord voor 'alles' in een vorm tegenkomen die voor een slavist volstrekt onherkenbaar is: вoxo in het cyrillisch, oftewel vocho (in de moderne Russische standaardtaal всё, d.w.z. vsjo). De koopman Moisej, die dit woord schreef (nr. 439, p. 44), was beslist 
geen halve analfabeet; hij spelde volgens het alternatieve systeem en schreef zijn eigen taal (met de uitspraak -ch-in plaats van -s-).

Hoewel we dus veel meer weten over de taalstructuur van het Oudnovgorods, blijft het lastig om berkenbastteksten goed te interpreteren. Vaak duiken er onbekende woorden of woordbetekenissen op omdat de inhoud zo kan verschillen van die van ander historisch bronnenmateriaal. Waar elders vinden we bijvoorbeeld een goede parallelle context voor het werkwoord dat cruciaal is in de interpretatie van de opmerkelijke brief nr. 954 (zie p. 92)?

In meer recente tijd heeft onderzoek naar de taal op berkenbast ook plaatsgevonden op het terrein van de historische pragmatiek en sociolinguïstiek. Wat de pragmatiek betreft zijn veel vorderingen gemaakt in de studie naar communicatieve uitdrukkingsmogelijkheden van de briefschrijver. Daarbij spelen zijn of haar oriëntatiepunt in tijd en plaats een belangrijke rol. Een goed voorbeeld is nr. 879 (p. 139) waarin Zjirjata zijn instructie formuleert gezien vanuit het leesmoment van Radjata: 'Geef aan deze (man) wat hij heeft gezegd', d.w.z. 'de man die nu voor je staat en jou zojuist een mondelinge mededeling heeft gedaan'. Verrassend is Staraja Roessa nr. 15 die is gecomponeerd alsof de schrijver, Petr, ter plekke Vasilj en Vysjata een voor een toespreekt (zie verder p. 150).

Meer van dit type teksten zijn opgenomen in het deel Communicatie (p. 131 e.v.). Ook daarbuiten komen we teksten tegen met vergelijkbare constructies, meer specifiek wanneer het gaat om vaak voorkomende uitdrukkingen van het type 'ik heb je dit en dit gestuurd (met die of die persoon)'. Er staat altijd in de verleden tijd 'ik heb gestuurd', maar betekent dit dat eerst de spullen zijn verstuurd en pas daarna het briefje? Heeft Grigorja zijn brief (Staraja Roessa nr. 39, zie p. 46) echt pas achteraf verzonden, toen de zes vaten wijn al op weg waren naar of zelfs in het bezit waren van Jermola en Ozekej? Aangezien hij schrijft dat ze goed de hoeveelheid wijn in de vaten moeten controleren, verwacht hij blijkbaar dat de brief min of meer tegelijkertijd met de vaten arriveert. De meest efficiënte en betrouwbare manier is uiteraard om brief en goederen samen 
te sturen. Als dat inderdaad is gebeurd, dan kan Grigorja's gebruik van de verleden tijd in 'ik heb je zes vaten wijn gestuurd' alleen verklaard worden door aan te nemen dat ook hij zich verplaatst in het leesmoment van de twee geadresseerden: voor hen lag de handeling van het sturen immers in het verleden. Een dergelijke verklaring is zeer goed mogelijk aangezien we dit specifieke taalverschijnsel ook uit andere oude schrijfculturen kennen (overgeleverde correspondentie in het Latijn en Grieks, en brieven in verschillende Semitische talen). Het staat bekend onder de naam 'epistolaire tijd'.

In sociolinguïstisch opzicht gebeurt er van alles op berkenbast. Er waren verschillende taalregisters, variërend van 'authentiek' Novgorods tot 'zuiver' Kerkslavisch. Het laatste uiteinde van het spectrum was als taal van de kerk gestandaardiseerd, zij het slechts tot op zekere hoogte en afhankelijk van de kwaliteiten van de individuele kopiist. Berkenbastteksten in het Kerkslavisch bestaan, maar zijn in de absolute minderheid (een stuk of veertig) en inhoudelijk sterk verbonden met de religieuze levenssfeer. Zie bijvoorbeeld het berkenbastboekje met avondgebeden (nr. 419, p. 112) of de bezweringsformules nr. 715 en nr. 734 (p. 113). Soms vinden we ook een mix van Kerkslavisch en Novgorods, zoals in de briefwisseling tussen de twee monniken Efrem en Isoechija (nr. 605, p. 107). In principe schrijft Efrem in zijn eigen taal, maar hier en daar sluipen er elementen in die hij uit Kerkslavische boeken moet hebben gekend en die verder zeer ongebruikelijk zijn op berkenbast.

Buiten het Kerkslavisch bestond er op berkenbast geen 'standaard', zeker niet zoals wij die in moderne talen als het Nederlands of Russisch kennen. Er bestond wel een gevoel voor taalregisters, bewust of onbewust, althans bij een aantal schrijvers. Dat gevoel had niet zo zeer te maken met keuzes tussen beide uiteinden van het sociolinguïstische spectrum (van 'echt' Novgorods tot 'echt' Kerkslavisch). Het lag subtieler: sommige briefschrijvers wisselen binnen een en dezelfde tekst lokale taalelementen af met een 'algemenere', supraregionale variant van het Russisch. Die variant werd blijkbaar als sociaal prestigieus ervaren en gepast op momen- 
ten wanneer de status van de mededeling van belang was. Een mooi voorbeeld is nr. 724 (p. 122). In de hoofdtekst, op de buitenkant van de berkenbast, vermijdt de briefschrijver Sava specifieke taalkenmerken van het Oudnovgorods. Zo kiest hij in plaats van de lokale naamvalsuitgang - $e$ consequent de variant die we elders in het Russisch aantreffen. In het postscriptum op de binnenkant heeft hij echter geen moeite met die uitgang - $e$ en met andere Novgorodse taal- en spellingverschijnselen.

Een ander geval is de rapportage van Toek aan Gjoerjata in nr. 907 (p. 59). Toek permitteert zich in eerste instantie om lokaal Novgorods te schrijven, ook al richt hij zich direct tot de man die op dat moment stadhouder was van Novgorod. Maar wanneer hij in het vervolg van zijn tekst aanvullende bevindingen meedeelt - bevindingen die waarschijnlijk zijn gebaseerd op nadere informatie van de hooggeplaatste informant Ivanko of leden uit diens milieu - dan verruilt hij specifiek Novgorods voor supraregionale taalvarianten.

De sociolinguïstische situatie in nr. 907 doet denken aan Novgorod nr. 142 (ca. 1300-1320). De briefschrijver, Esif, gebruikt in zijn tekst de al genoemde lokale naamvalsuitgang $-e$, behalve wanneer hij in directe rede een instructie geeft die de geadresseerde moet overbrengen aan een zekere Mark: ... antwoord hem als volgt: "Zoals, jij, Mark, met mij geregeld hebt, heb ik me verplicht om op het Hoogfeest van de Heilige Petrus naar jou toe te komen ...". In zijn directe 'geautoriseerde' verklaring kiest hij juist voor de variant die buiten zijn eigen Novgorodse taalgebied wordt gebruikt.

Sava in nr. 724, Toek in nr. 907 en Esif in nr. 142 hebben bewust of onbewust gebruikgemaakt van de taalregisters die in middeleeuws Novgorod voorhanden waren: lokaal en supraregionaal. De monnik Efrem voegt daar in nr. 605 nog een dimensie aan toe: het Kerkslavisch. In sociolinguïstisch opzicht gebeurt er inderdaad van alles op berkenbast. 


\section{Teksten I: Dagelijks leven}

De teksten die in dit deel zijn opgenomen zijn een eerste selectie uit het gehele berkenbastcorpus. Een fors aantal daarvan kon niet worden gebruikt voor dit boek. Zoals al is gezegd in het vorige hoofdstuk, zijn veel stukjes berkenbast zo fragmentarisch overgeleverd dat de inhoud niet of nauwelijks te achterhalen valt. Er zijn ook teksten die wel volledig zijn overgeleverd, maar die filologisch en taalkundig dermate gecompliceerd zijn dat een plausibele interpretatie haast onmogelijk is.

Desalniettemin blijven er ruim voldoende teksten over die wel goed te begrijpen zijn. Een deel daarvan wordt hier thematisch gepresenteerd. De selectie moet de verscheidenheid van onderwerpen op berkenbast weerspiegelen, die tezamen een veelzijdige indruk geven van het dagelijkse leven in middeleeuws Novgorod en andere oude Russische steden.

De volgorde van de thema's is grotendeels bepaald door de hoeveelheid materiaal dat op berkenbast is overgeleverd. Als eerste komen teksten over handel, geld, recht en bestuur ter sprake, want daar gaat het meestal over op berkenbast. Brieven die met kerk en religie te maken hebben, die getuigen van grote historische gebeurtenissen of niet in het Slavisch zijn geschreven, zijn minder in aantal en worden pas verderop in de selectie behandeld. Een meer gespecialiseerd thema is Leren lezen en schrijven op berkenbast (zie p. 101 e.v.), waarin wordt nagegaan wat de teksten zelf ons hierover kunnen vertellen.

Een tweede selectie uit de verzameling wordt gepresenteerd in het deel Communicatie (p. 131 e.v.). Hier worden de teksten vanuit een andere invalshoek benaderd: de interactie tussen het gesproken en geschreven woord en de speciale rol die de koerier gespeeld moet hebben bij de overdracht van mededelingen over een grote afstand waarbij directe mondelinge communicatie onmogelijk was. 


\section{Handel en geld}

Grivna's, eekhoornvellen en sabelbont

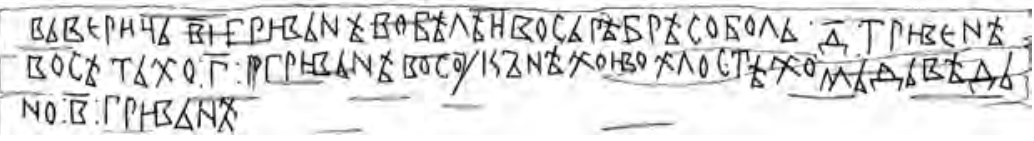

Novgorod nr. 722, ca. 1200-1220

12 grivna's geld in eekhoornvellen en in zilver. Sabelbont: 4 grivna's. In netten, in laken en in linnen: 3 grivna's. Berenhuid: 2 grivna's.

Een grivna is een bepaald gewicht aan zilver in de vorm van een staafje. Zilvereenheden en dierenhuiden, met name de koena (martervel), vormden in middeleeuws Novgorod de basis van het betalingsverkeer. Geslagen munten waren van de twaalfde tot de tweede helft van de veertiende eeuw niet in gebruik.

Nr. 722 is een typische lijst van goederen, waarvan we er veel op berkenbast aantreffen. Het kan gaan om administratie, bijvoorbeeld schulden die nog geïnd of betaald moeten worden, maar ook om 'vrachtlijstjes' die aan de vervoerder mee werden gegeven. Er zijn ook lijstjes overgeleverd van ontvangen huwelijksgeschenken (nrs. 261-264, ca. 1360-1380) en van huishoudelijke spullen, zoals Novgorod nr. 586 (ca. 1100-1120):

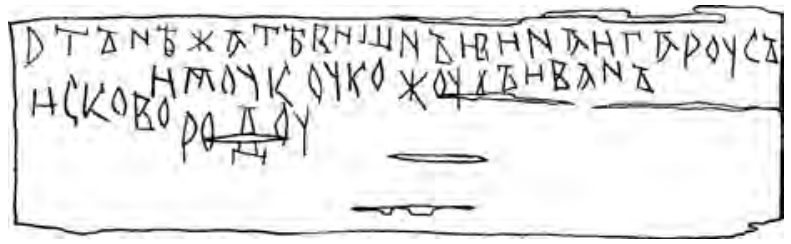

Van Nezjata kersen en wijn en azijn en meel, de jas van Ivan, en een pan. 


\section{Koena's, rezana's en veksja's}

Novgorod nr. 926, ca. 1200-1220

4 grivna's voor Techons paard. Aan zijn zoon: een grivna. Aan Mikifor: vijfenhalf koena en een grivna. Aan de zoon van Gjoelopa: 7 koena's. Aan de man uit Pskov: achtenhalf koena. Aan Domasjko: achtenhalf rezana. Voor zout: een koena. Voor de vis: 2 koena's. Voor visolie: 9. Wat de visingewanden betreft: 4 veksja's.

Dit is een ander voorbeeld van een lijstje, dat blijkbaar een opsomming is van uitgaven die gemaakt zijn of geraamd worden. De uitgaven worden van groot naar klein vermeld: eerst in grivna's, dan in koena's ( 1 grivna $=25$ koena's), vervolgens in rezana's ( 1 grivna $=50$ rezana's) en tot slot in de kleinste eenheid, de veksja, oftewel eekhoornvelletje (1 grivna $=150$ veksja's). Voor Techons paard moest dus een equivalent van 600 eekhoornvelletjes neergelegd worden.

De getallen 'vijfenhalf' en 'achtenhalf' staan letterlijk genoteerd als 'de helft van de zesde', resp. 'negende'; een destijds gebruikelijke constructie die we nog kunnen aantreffen in ons Nederlandse 'anderhalf' (de helft van de ander, d.w.z. tweede).

Op het eind van de lijst staat zout vermeld, dat als conserveermiddel verbonden moet worden met de daarna genoemde vis, visolie en de visingewanden (kuit en hom). 
'Drie ladingen met was zijn gekocht'

Novgorod nr. 439, ca. 1200-1220

+ Van Moisej aan Spirko. Als Matej de lading niet van jou genomen heeft, stuur haar dan met Proes naar mij. Ik heb het tin en het lood en al het smeedwerk verkocht. Ik hoef niet meer naar Soezdal te gaan. Drie ladingen met was zijn gekocht. Je moet hierheen komen. Stuur tin mee, ongeveer vier maten en een paar rode koperplaten. En betaal het geld per omgaande.

De afzender, Moisej, heeft blijkbaar goede zaken gedaan en vraagt nu aan zijn compagnon in de stad om naar hem toe te komen en extra spullen te sturen. Aan het specifieke woord voor 'lading' (kap) in het begin van de brief is te zien dat het onder andere om was gaat. Was en honing waren naast dierenhuiden de belangrijkste handelsproducten van Novgorod.

De stad Soezdal ligt hemelsbreed ongeveer zeshonderd kilometer ten oosten van Novgorod (zie de kaart op p. 20) en behoorde tot een apart vorstendom (Vladimir-Soezdal). Het had een strategische en rivaliserende positie in Novgorods handel langs de Wolga-route met de Wolga-Bulgaren en verder gelegen moslimlanden. 
'Ksinofont heeft de zaken voor ons verknoeid'

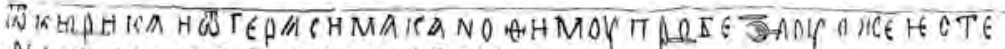

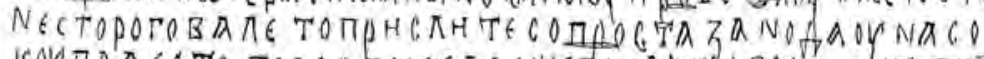

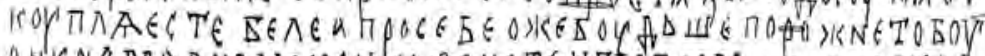

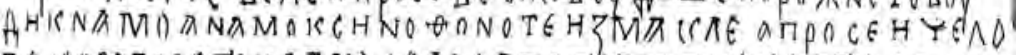

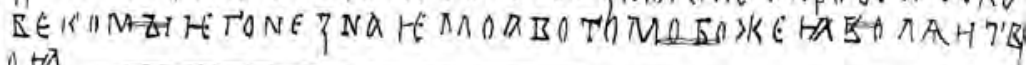

Pskov nr. 6, ca. 1260-1280

Van Kjoerik en van Gerasim aan Onfim. Wat betreft de eekhoornvellen: als jullie ze nog niet hebben verhandeld, stuur ze dan onmiddellijk, want er is bij ons vraag naar eekhoornvellen. Wat betreft onszelf: als je vrij bent, kom dan naar ons, want Ksinofont heeft de zaken voor ons verknoeid. En wat deze man betreft: we kennen hem niet. En in deze zaak beslissen God en jij.

Uit de stad Pskov, die zo'n tweehonderd kilometer ten zuidwesten van Novgorod ligt (vlak bij de huidige grens met Estland), zijn acht berkenbastteksten overgeleverd. Pskov was oorspronkelijk deel van het Novgorodse land, maar maakte zich los tegen het eind van de dertiende eeuw, dus in de periode van brief nr. 6 .

Het is niet helemaal duidelijk naar wie op het eind van de brief wordt verwezen met 'deze man' ('En wat deze man betreft: ...). Het zou om de genoemde Ksinofont kunnen gaan, die schade heeft berokkend en die Kjoerik en Gerasim nu blijkbaar niet meer zien zitten ('we kennen hem niet').

De brief eindigt met een formule waarin God wordt aangehaald. Dergelijke formules komen wel vaker en in verschillende constructies voor op berkenbast. De schrijver geeft er mee aan dat hij zijn lot in handen van de aangesprokene legt en dat hij vertrouwt op een goede afloop (vergelijk nr. 311, p. 76, en nr. 549, p. 111). 
'Ik heb je zes vaten wijn gestuurd'

Staraja Roessa nr. 39, ca. 1380-1400

Groet van Grigorja aan Jermola en Ozekej. Ik heb je zes vaten wijn gestuurd, vol tot waar de vinger reikt. Kijk het goed na en verkoop ze als de andere, op dezelfde condities. En heb je ze verkocht, stuur dan de opbrengst. En geef niet het geld aan mijn kinderen (?); stuur het samen met (je) schuld.

Staraja Roessa ligt honderd kilometer ten zuiden van Novgorod, aan de andere kant van het Ilmenmeer. De stad was met name belangrijk vanwege de zoutindustrie. Hier gaat het echter niet om zout, maar om wijn, een importproduct dat zowel vanuit het westen (rijnwijn) als vanuit het zuiden, Byzantium, werd aangevoerd.

Grigorja is bezorgd dat er onderweg wijn wordt verspild of opgedronken en gebruikt in zijn brief de uitdrukking 'vol tot waar de vinger reikt', d.w.z. de vaten mochten niet minder wijn bevatten dan een vingerlengte gemeten vanaf de deksel. De inhoud moest letterlijk 'toereikend' zijn. Over de vraag of de brief tegelijkertijd is verstuurd met de vaten zie p. 38 .

Tot nu toe zijn 45 berkenbastjes opgegraven in Staraja Roessa. Opmerkelijk is het verhoudingsgewijs grote aantal vrouwen dat er in figureert. Zo hebben we lijsten van schuldenaren die geheel of hoofdzakelijk uit vrouwennamen bestaan.

Uit Staraja Roessa hebben we ook het volgende glasheldere bericht van een vrouw aan een zekere Fima overgeleverd gekregen (Staraja Roessa nr. 11, ca. 1160-1180):

vans vrouw zegt tegen Fima: of je stuurt het geld of ik eis dat je zwaar beboet wordt. 
'Het brood is hier namelijk goedkoop'

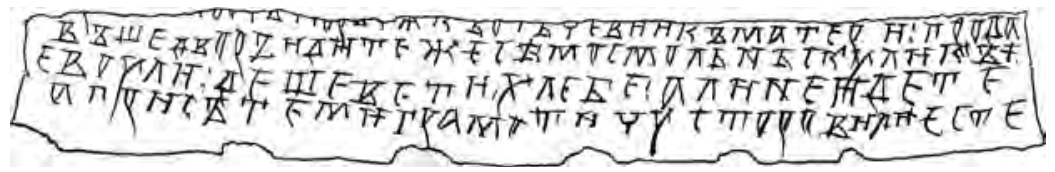

Novgorod nr. 424, ca. 1100-1120

Brief van Gjoergi aan vader en aan moeder. Verkoop de hoeve, kom hierheen - naar Smolensk of naar Kiëv. Het brood is hier namelijk goedkoop. Als jullie niet komen, stuur me dan een briefje, of het goed met jullie gaat.

Deze brief gaat weliswaar niet over handel en geld, maar zegt wel iets over de economie van Novgorod. Vanwege de weinig vruchtbare Novgorodse bodem moesten nogal wat goederen geïmporteerd worden en was het leven relatief duur. Uit de kronieken weten we dat er herhaaldelijk hongersnoden in de stad waren.

Gjoergi bevindt zich blijkbaar ergens in het zuiden en weet dat de leefomstandigheden in Smolensk en in Kiëv (vierhonderd resp. negenhonderd kilometer verderop) beter zijn.

Gjoergi schrijft deze brief aan zijn beide ouders in een tijd dat er in het Russisch behalve een enkelvouds- en meervoudsvorm ook een 'tweevoudsvorm' (dualis) bestond. Toch gebruikt hij uitsluitend meervoudsvormen. Blijkbaar had hij niet alleen zijn ouders, maar het hele gezin en huishouden in gedachten. 
'Voer het met Drotsjila uit volgens afspraak'

Novgorod nr. 344, ca. 1300-1320

Van Petr aan Koezma. Ik geef jou, mijn broer, instructies betreffende onszelf als volgt: Of hij nou met jou iets heeft geregeld of niets heeft geregeld, voer het met Drotsjila uit volgens afspraak. En ik buig voor jou.

Dit is de onderste laag van een berkenbast, waardoor de letters moeilijk te lezen zijn. De bovenlaag zou gebruikt kunnen zijn als kopie voor Petr (vergelijk de volgende brief, nr. 736).

In de brief geeft Petr zijn broer aanwijzingen in wat een business deal lijkt te zijn die is gesloten met Drotsjila. Het doet er niet toe wat Drotsjila verder met Koezma regelt; de deal moet gewoon worden uitgevoerd. Wellicht denkt Petr dat Koezma een schriftelijke bevestiging van de deal wil, terwijl de mondelinge overeenkomst volgens hem voldoende is. 


\section{'Van Ivan aan Dristliv' en 'Van Dristliv aan Ivan'}

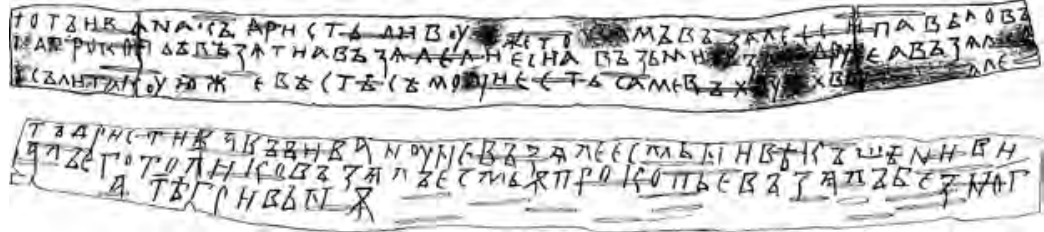

Novgorod nr. 736, ca. 1100-1120

(Buitenkant) + Van Ivan aan Dristliv. Als jij de rente van Pavel hebt genomen, dan moet je ze nemen van Prokopja. Als je die (al) hebt genomen, neem dan (ook voor Zavid). Als je die (ook al) hebt genomen, stuur dan bovendien een bericht hierheen, of hij zelf de hele rente heeft afgegeven.

(Binnenkant) Van Dristliv aan Ivan. Ik heb geen cent genomen en hem niet gezien. Ik heb alleen van Prokopja genomen; ik heb genomen een grivna minus een nogata.

Het is duidelijk dat de tekst van Dristliv op de binnenkant het antwoord is op de reeks instructies van Ivan op de buitenkant. Van de buitenkant is alleen de onderste laag bewaard gebleven, die daarom ook lacunes bevat. Wellicht heeft Dristliv de bovenlaag voor zichzelf gehouden toen hij zijn antwoord op de andere kant schreef (vergelijk de vorige brief, nr. 344). Brieven plus antwoord zijn op berkenbast erg zeldzaam (vergelijk nr. 497, p. 147).

De 'hij' in de laatste zin van Ivan kan slaan op Prokopja of Zavid; de 'hem' in de brief van Dristliv verwijst waarschijnlijk naar Pavel. Voor 'geen cent' in de betekenis van 'helemaal niets' gebruikt Dristliv - net als in het Nederlands en andere talen - de kleinste geldeenheid die er bestond: de veksja (vergelijk nr. 926, p. 43). Een nogata is overigens $1 / 20$ grivna. 


\section{'Doe normaal!'}

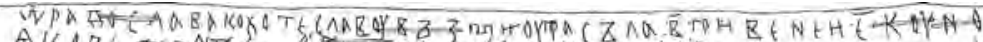

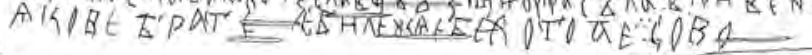

Staraja Roessa nr. 35, ca. 1140-1160

Van Radoslav aan Choteslav. Neem van de handelaar 2 grivna's en 5 koena's. | Jakov, broer, doe normaal, naaier, kloothommel!

De tweede regel, beginnend met 'Jakov', is in een ander handschrift dan de eerste. Dit, in combinatie met de inhoud, doet vermoeden dat we net als in de vorige brief, nr. 736, te maken hebben met een brief plus antwoord (zie ook nr. 497, p. 147). Daarbij spreekt Choteslav zijn broer Radoslav aan met zijn doopnaam Jakov, zo te zien uit sarcasme. Want het taalgebruik dat volgt, liegt er niet om. Voor wat hier als 'doe normaal' is weergegeven gebruikt hij de sprekende uitdrukking 'neuk liggend'. Daarna volgen twee woorden die letterlijk 'neuk-willer' (ebechota) en 'eier-steker' (aesova) betekenen.

Choteslav scheldt zijn broer dus op zeer originele wijze uit voor de in zijn ogen ongepaste opdracht. Maar is dat wel zo? Er bestaat een andere interpretatie die ervan uitgaat dat de eerste zin is geschreven door een derde persoon en dat de tweede zin is toegevoegd door Radoslav zelf. Jakov zou dan de doopnaam zijn van Choteslav, wiens naam als woordspeling doorklinkt in de twee genoemde scheldwoorden: ebechota en aesova (Choteslav).

In deze alternatieve verklaring moet het 'postscriptum' van Radoslav gezien worden als een speels onderonsje tussen twee broers. Radoslav contrasteert de christelijke naam van zijn broer in een en dezelfde zin met diens roepnaam en verpakt deze in twee originele schuttingwoorden. 
'Van Ondrej drie denga's'

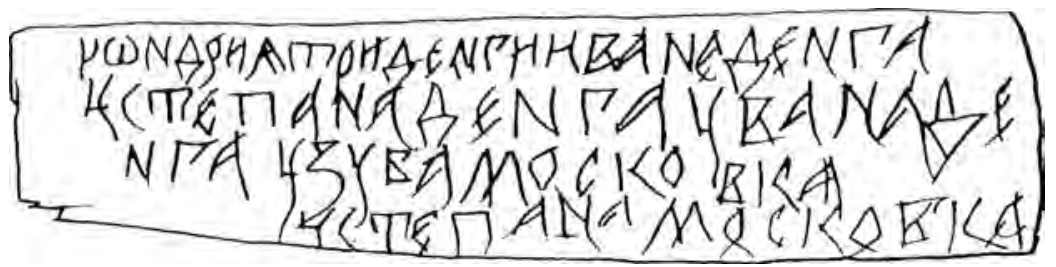

Novgorod nr. 495, tweede helft vijftiende eeuw

Van Ondrej drie denga's, Ivan een denga, van Stepan een denga, van Ivan een denga, van Zub een moskovka, van Stepan een moskovka.

Deze berkenbasttekst is archeologisch de jongst gedateerde uit Novgorod en stamt uit de periode waarin de stad haar onafhankelijkheid verloor aan Moskou (1478).

Nr. 495 is een van de vele lijstjes die op berkenbast zijn overgeleverd (vergelijk nr. 722, p. 42, en nr. 926, p. 43). In dit geval gaat het zo te zien om een opsomming van debiteuren. De verschuldigde eenheden betreffen echte munten die in de tweede helft van de veertiende eeuw in omloop kwamen: de (Novgorodse) 'denga' (vergelijk dengi 'geld' in het modern Russisch) en de Moskouse variant, de 'moskovka', die de helft van de Novgorodse waarde had. 
Nummer 1000

Novgorod nr. 1000, tweede helft twaalfde eeuw Van Kyas en van Zjirotsjko aan Tverdjata en aan Ivan. We maken het beiden goed.

Het jubileumnummer 1000 mag in dit boek niet ontbreken. De berkenbast is gevonden op 21 juli 2010. In dat jaar werden in totaal 42 nieuwe teksten opgegraven in Novgorod (nrs. 974-1015), en één in Staraja Roessa (nr. 43).

Het lijkt erop dat nr. 1000 een simpel berichtje is van het type 'Groeten uit .... Dergelijke boodschappen met weinig communicatieve inhoud zijn echter atypisch voor berkenbastteksten; gewoonlijk gaat het écht ergens over. Andere vondsten uit hetzelfde jaar doen vermoeden dat nr. 1000 inderdaad meer is dan een 'ansichtkaart'.

Een van de twee geadresseerden, Ivan, kan in verband gebracht worden met een zekere Loeka, van wie op precies dezelfde plek in 2010 meerdere brieven zijn opgegraven. Een daarvan is Novgorod nr. 1009, die is gevonden op 6 augustus 2010 in dezelfde bodemlaag als nr. 1000:

Van Loeka en van Ivan aan Snovid. We maken het beiden goed. We hebben het onze al verkocht. De Griekse waar hebben we niet gekocht. Zoek dus overzeese waar.

Uit deze brief komt duidelijk naar voren dat Ivan en Loeka zakenpartners zijn: ze zijn op reis, hebben hun eigen spullen weten te verhandelen, maar de 'Griekse waar', d.w.z. goederen uit Byzantium, niet gekocht. Ze vragen nu aan Snovid om 'overzeese waar', uit WestEuropa, op de kop te tikken. 
Als we alle vondsten uit 2010, met daarin de namen van Loeka, Ivan en Snovid, in ogenschouw nemen (zie ook nr. 999, p. 163, en nrs. 1004 en 1006, p. 141), dan rijst het vermoeden dat de eerste twee personen niet alleen compagnons in de internationale handel waren, maar ook broers, en dat Snovid hun vader was. Het is ook niet uitgesloten dat Snovid dezelfde persoon is als in brief nr. 955 (p. 90), die gaat over het aanstaande huwelijk van Snovid met Grote Vlecht.

Terugkomend op nr. 1000: het is zonder meer denkbaar dat deze in dezelfde categorie business letters valt als nr. 1009: Kyas - een opmerkelijke naam waarvan de etymologie vooralsnog onduidelijk is: Turks? Slavisch? - en Zjirotsjko melden aan hun zakenpartners Tverdjata en Ivan dat de handel, waar ze een gemeenschappelijk belang in hebben, voorspoedig verloopt. 


\section{Recht en bestuur}

\section{'Maar het slot is heel en de deuren zijn heel'}

Novgorod nr. 247, ca. 1025-1050

... beschuldigt deze van een schade van 40 rezana's. Maar het slot is heel en de deuren zijn heel, en de eigenaar doet daarom geen aanklacht. Dus beboet die beschuldiger. En van deze boer moet de bisschop krijgen (die en die geldsom?) ... de boeren (willen, kunnen?) de beschuldiger slaan ...

Dit is een van de twee oudste berkenbastbrieven die zijn overgeleverd (vergelijk nr. 246, p. 58). Begin en eind ontbreken en het laatste stuk van de tekst is niet helemaal duidelijk. Voor taalkundig commentaar zie p. 36.

We lijken te maken te hebben met een rapport over de uitkomst van een juridisch conflict waarbij iemand is beschuldigd van diefstal. Nader onderzoek heeft echter uitgewezen dat er geen sporen van braak zijn ('het slot is heel en de deuren zijn heel')en dat het om een valse beschuldiging gaat die bestraft moet worden met een geldboete.

De vermelding van de bisschop is niet vreemd aangezien hij niet alleen kerkelijke zaken beheerde, maar ook een belangrijke bestuurlijke functie in het Novgorodse stadsleven vervulde. Blijkbaar heeft de bisschop het gerechtelijk onderzoek uitgevoerd en moet hij nu voor zijn werk door de boer (smerd 'vrije boer') betaald worden. Waarschijnlijk is die boer degene die valselijk beschuldigd is.

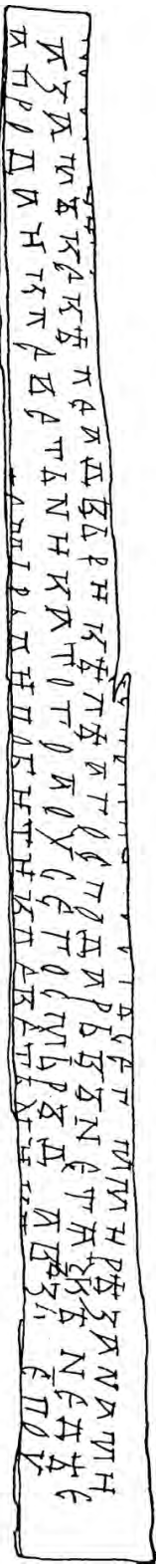


'Je hebt een slavin in Pskov gekocht'

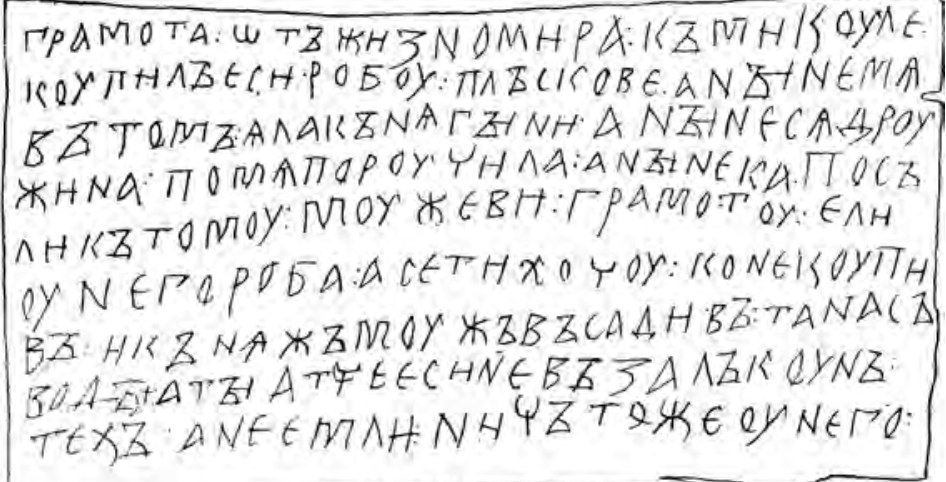

Novgorod nr. 109, ca. 1100-1120

Brief van Zjiznomir aan Mikoela. Je hebt een slavin in Pskov gekocht. En nu heeft de vorstin mij daarom gevangengenomen en moest mijn gevolg borg staan. En daarom, stuur een brief naar die man of de slavin in zijn bezit is. En dit is wat ik wil doen: paarden kopen, een edelman erop zetten, en dan op naar het verhoor. En jij, als je het geld niet genomen hebt, neem dan niets van hem.

Over wat er in deze brief precies aan de hand is bestaan meerdere verklaringen. De meest plausibele is dat Zjiznomir aansprakelijk is gehouden voor Mikoela's aankoop van een slavin, die op enig eerder moment onrechtmatig verhandeld is. Zjiznomir is vastgezet, maar intussen weer vrijgekocht. Mikoela heeft de slavin doorverkocht en Zjiznomir vraagt hem om haar te traceren en om geen geld aan te nemen van de koper, mocht dat nog niet gebeurd zijn.

Zelf moet Zjiznomir naar het verhoor, de svod, gaan, waarbij hij wordt ondervraagd over de rechtmatigheid van de aankoop. Blijkbaar zoekt hij de steun van een hooggeplaatst persoon, een vertrouweling van de vorst, en wil hij voor hem en voor zichzelf paarden regelen om naar het verhoor te kunnen gaan. 
'Als je ze niet stuurt, stap ik naar de vorst'

W

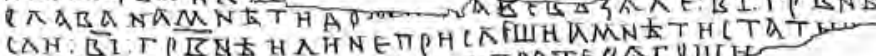

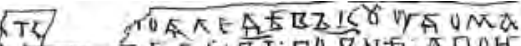

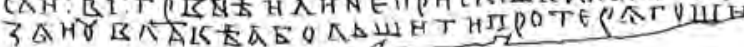

Novgorod nr. 155, ca. 1160-1180

+ Van Polotsjko aan ... Nadat jij een meid genomen hebt van Domaslav, heeft Domaslav van mij 12 grivna's genomen. Stuur dus 12 grivna's. Als je ze niet stuurt, stap ik naar de vorst en de bisschop; reken dan op een groter verlies ...

Polotsjko wil zijn geld terug dat hij aan Domaslav heeft afgestaan voor een 'meid' die de laatste heeft gegeven aan de onbekende ontvanger van de brief. Gebeurt dat niet, dan dreigt Polotsjko met juridische stappen door het bevoegd gezag, waaronder de bisschop (vergelijk nr. 247, p. 54), in te schakelen. Dat komt de schuldenaar dan op hogere kosten te staan.

De opmerking dat de geadresseerde 'een meid genomen' heeft en dat hij daarvoor geld moet betalen, wijst op de koop van een slavin.

Zoals te zien is op de tekening, ontbreekt een stuk van de eerste regel, precies op de plaats waar de naam van de geadresseerde zou moeten staan. Het is goed mogelijk dat de brief door de geadresseerde is geanonimiseerd, hetgeen een variant is op de praktijk om brieven na lezing te verscheuren (vergelijk nr. 752, p. 87). De schrijver van Novgorod nr. 881 (ca. 1120-1140) draagt dit uitdrukkelijk op aan de ontvanger: ... verscheurd hebbende de brief in reepjes... 
'Betaal Stepanets vóór Kerstmis'

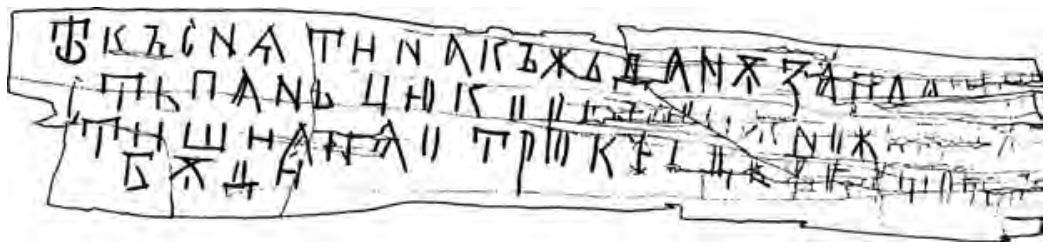

Novgorod nr. 241, ca. 1100-1120

Van Kosnjatin aan Zjdan. Betaal Stepanets vóór Kerstmis. Betaal je niet, dan zul je bij de deurwaarder wel twee keer zo veel kwijt zijn. Voor het woord 'deurwaarder' staat in het Russisch otrok, waarmee gewoonlijk een soort van gerechtsambtenaar wordt aangeduid die zelfstandig of in opdracht van hogere functionarissen kon opereren. In berkenbastteksten vinden we hem meestal in de rol van inner van schulden. Omdat de otrok ook zijn loon moet krijgen, wordt het voor Zjdan een dure aangelegenheid wanneer hij Stepanets niet binnen de gestelde termijn betaalt.

Nr. 241 toont veel gelijkenis met brief Staraja Roessa nr. 15 (p. 150). Dit geeft aanleiding om te vermoeden dat de afzender, Kosnjatin, een zekere bevoegdheid heeft in het geschil en dat we te maken hebben met een mandaatbrief die Stepanets van hem heeft meegekregen en waarmee hij Zjdan onder druk kan zetten. 
'Stuur ze dus goedschiks'

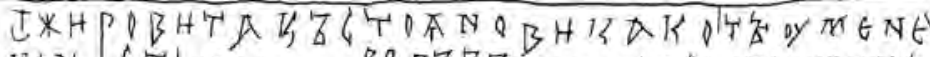

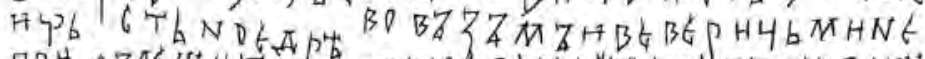

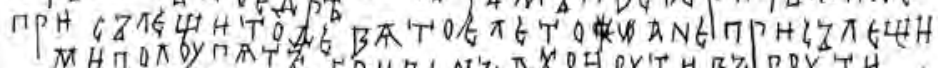
MH HOR by

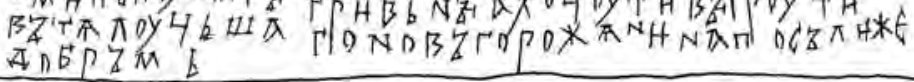

Novgorod nr. 246, ca. 1025-1050

Van Zjirovit aan Stojan. Het is het negende jaar sinds je van mij het Heilige Hout hebt genomen en mij het geld niet stuurt. Als je me de vierenhalve grivna niet stuurt, zal ik ten laste van jou goederen confisqueren van de voornaamste Novgoroder. Stuur ze dus goedschiks.

Samen met nr. 247 (p. 54) behoort nr. 246 tot de oudste brieven op berkenbast. Hij moet verstuurd zijn vanuit een plaats die niet tot Novgorod behoorde, want er is sprake van een bekende procedure die roebezj heette en die uitging van collectieve verantwoordelijkheid: burgers van een bepaalde stad konden buiten de jurisdictie van hun eigen gebied verantwoordelijk worden gehouden voor een vergrijp van een medeburger in datzelfde gebied (zie bijvoorbeeld ook nr. 952, p. 134). In dit geval dreigt Zjirovit goederen in beslag te nemen van de 'voornaamste Novgoroder' die in zijn stad is. De stad waarin Zjirovit zich bevindt zou gezien de taalkundige kenmerken van de brief Smolensk, Vitebsk of Polotsk kunnen zijn (zie de kaart op p. 20).

Met het 'Heilige Hout' in de openingszin wordt het Kruis bedoeld. Dit zou opgevat kunnen worden als 'een eed afleggen; zweren' (op het Kruis, dat het geld zal worden terugbetaald). Voor die interpretatie hebben we echter geen parallellen in het Oudrussisch. Een alternatieve verklaring, waar wel indicaties in andere bronnen voor zijn, is dat we de woorden letterlijk moeten nemen: Stojan heeft van Zjirovit een kruis gekregen als relikwie en is niet over de brug gekomen met het verschuldigde bedrag. 
'En nu heeft hij samengezworen met zijn familie'

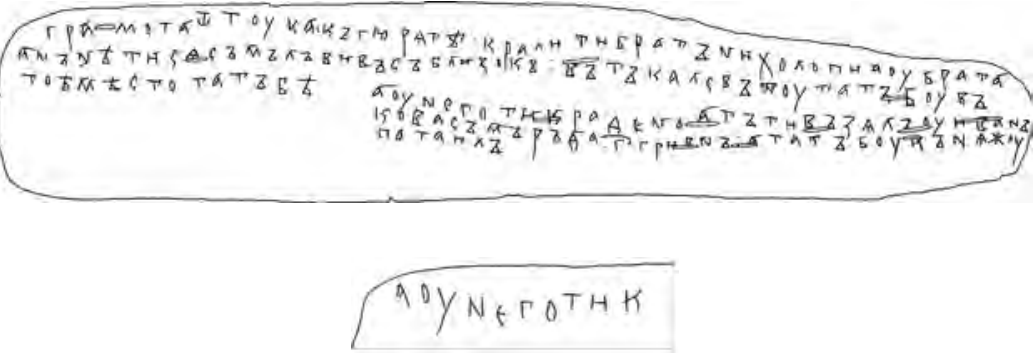

Novgorod nr. 907, ca. 1100-1120

(Buitenkant) Brief van Toek aan Gjoerjata. De bedienden van de broer hebben gestolen, ze hebben van zijn broer gestolen. En nu heeft hij samengezworen met zijn familie; hij heeft alles op deze diefstal afgewenteld, in plaats van te vertellen over die diefstal. Er is van hem (in zijn district) inderdaad gestolen, maar in feite heeft hij van Ivanko's boer 3 grivna's genomen en de diefstal van het bezit van de vorst verzwegen.

(Binnenkant) Er is van hem

Op de grotere afbeelding van de buitenkant van de berkenbast is te zien dat de eerste drie regels grafisch zijn afgescheiden van de volgende drie, die midden op de berkenbast beginnen. Daarnaast zijn op binnenkant nog een paar letters geschreven: 'Er is van hem' (zie de kleinere afbeelding). Dit komt precies overeen met het begin van het tweede stuk op de hoofdzijde van de berkenbast. Blijkbaar is de schrijver bij dat tweede stuk eerst op de ene kant begonnen, bedacht hij zich vervolgens en ging hij verder op de andere kant, onder de eerste drie regels die hij al had geschreven.

De twee aparte stukken tekst op de buitenkant van de berkenbast en het verschillend taalgebruik dat erin wordt gebezigd (zie p. 40), duiden erop dat we te maken hebben met een gerechtelijk vooronderzoek dat Toek in twee etappes opschrijft. Het blijkt om 
een ingewikkelde zaak te gaan. Een niet nader genoemde persoon (' $\mathrm{X}$ ') is een functionaris die verantwoordelijk is voor 'het bezit van de vorst'. De boer (smerd) van een zekere Ivanko heeft uit dat bezit gestolen en $\mathrm{X}$ weet daarvan. In plaats van de diefstal openbaar te maken, neemt X drie grivna's van de boer als zwijggeld of simpelweg als boete die hij zelf houdt. De diefstal komt echter toch uit en Gjoerjata instrueert Toek om de zaak te onderzoeken.

Brief nr. 907 is Toeks verslag waarin hij eerst zijn bevindingen opschrijft over een eerdere diefstal die heeft plaatsgevonden in het huis van $\mathrm{X}$ : iets is ontvreemd van de broer van $\mathrm{X}$ door zijn eigen bedienden. X heeft vervolgens de diefstal uit het vorstelijk bezit waar hij verantwoording voor draagt - afgedekt door te beweren dat deze onderdeel was van de eerdere diefstal, begaan door de bedienden van zijn broer. Omdat de familieleden van $\mathrm{X}$ op de hoogte waren van de werkelijke gang van zaken, moest X ze heimelijk betrekken in zijn frauduleuze handelingen.

Toek rapporteert zijn bevindingen aan Gjoerjata, van wie we weten dat hij in de periode dat de brief werd geschreven de posadnik (stadhouder) van Novgorod was. Over Ivanko zie het netwerk 'Rondom Ivan en Nezjata' (p. 160). 
'Plaats hem dan voor de getuigen'

元爪 उZN H T

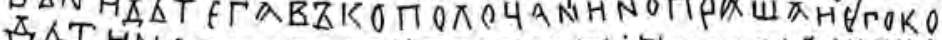

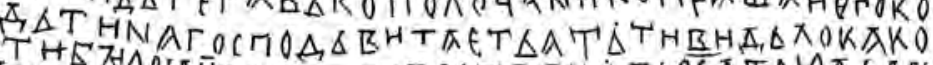

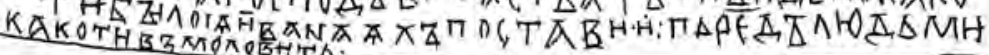

Novgorod nr. 502, ca. 1180-1200

Van Mirslav aan Olisej Gretsjin. Gavko de Polotsker komt er zo aan. Vraag hem waar hij kwartier maakt. Als hij gezien heeft hoe $i k$ Ivan heb gearresteerd, plaats hem dan voor de getuigen die hij noemt.

Op de plek waar nr. 502 is opgegraven, zijn nog meer brieven gevonden die aan dezelfde Gretsjin ('de Griek') zijn gericht. Hier figureert hij als gerechtsdienaar in een proces tegen Ivan dat aan de gang is. Gretsjin was echter ook priester en iconenschilder, zoals we in nr. 549 zullen zien (p. 111). Wereldlijke en geestelijke functies konden goed naast elkaar bestaan (zie ook nr. 247, p. 54, waar een bisschop bij een juridisch onderzoek is betrokken).

Van de afzender Mirslav wordt aangenomen dat het om de stadhouder Mirosjka Nezdinitsj gaat. Gavko komt gezien de toevoeging 'de Polotsker' blijkbaar (oorspronkelijk) uit de stad Polotsk, zo'n driehonderdvijftig kilometer ten zuidwesten van Novgorod (nu Wit-Rusland; zie de kaart op p. 20). 
'Maak een afschrift van de koopakte'

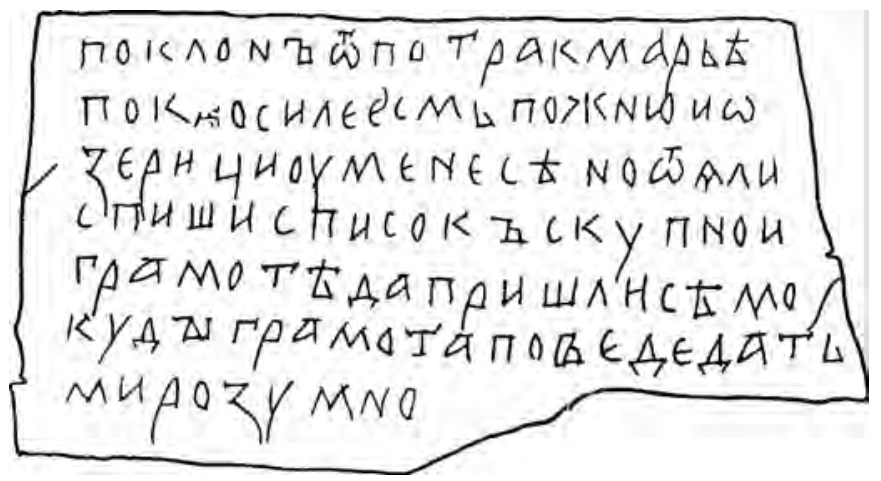

Novgorod nr. 53, ca. 1320-1340

Groet van Petr aan Marja. Ik heb het veld gemaaid en de bewoners van Ozero hebben het hooi bij me weggehaald. Maak een afschrift van de koopakte en stuur die hierheen, zodat me duidelijk is tot hoever de akte reikt.

Omdat er meerdere plaatsen in het Novgorodse land zijn die 'Ozero' (d.w.z. 'Meer') heten, kunnen we de herkomst van de brief niet precies bepalen. In ieder geval wil Petr een kopie van de koopakte van het maailand zodat hij kan aantonen waar de grenzen lopen. Blijkbaar bestaat daar onduidelijkheid over en meent Petr dat de bewoners van Ozero onterecht zijn hooi hebben weggenomen.

Misschien zijn Petr en Marja man en vrouw, maar het kan ook zijn dat ze mede-eigenaren zijn van het stuk land of dat Marja degene is die (een deel van) het land recentelijk aan Petr heeft verkocht of verpacht.

De officiële koopakte is ongetwijfeld op perkament geschreven en met de instructie 'maak een afschrift' wordt bedoeld dat Marja een kopie moet laten maken door een professionele schrijver. 
'Geef die aan de gerechtsdienaar'

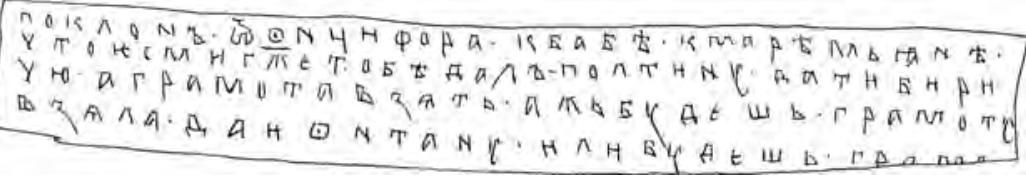

Novgorod nr. 578, ca. 1360-1380

Groet van Ontsifor aan grootmoeder Maremjana. Wat betreft de halve roebel, mevrouw, die ik je heb gegeven, geef die aan de gerechtsdienaar en neem het document. Als je het document al hebt, geef het aan Ontan. Als je het document ...

In de literatuur wordt aangenomen dat de afzender Ontsifor niet dezelfde is als de Ontsifor die nr. 354 (p. 149) en nr. 358 (p. 148) heeft geschreven. Daarvoor is de brief onder andere net iets te jong in vergelijking met de twee andere.

Interessant is dat deze brief - net als de vorige, nr. 53 - getuigt van de rol van officiële documenten in het dagelijkse leven. Het 'document' houdt, samen met het geld dat de gerechtsdienaar moet krijgen, op de een of andere manier verband met een juridische transactie of een rechtszaak die heeft plaatsgevonden. Daar schijnt ook een zekere Ontan bij betrokken te zijn.

De gerechtsdienaar wordt in de brief biritsj genoemd. In een Duits-Novgorods handelsverdrag uit 1268 wordt de functie als 'custos' vertaald ("custos qui dicitur biriz"). 
'Kom naar huis, zoon; je bent vrij'

Novgorod nr. 421, ca. 1120-1140

+ Van Bratjata aan Nezjil. Kom naar huis, zoon; je bent vrij. Als je niet komt, stuur ik een gerechtsdienaar naar je. Ik heb 20 grivna's betaald, en je bent vrij.

Bratjata heeft volgens het toenmalige recht zijn zoon moeten vrijkopen, die blijkbaar een geldstraf aan zijn broek heeft en zich schuilhoudt. Hij is echter bang dat Nezjil niet terugkomt. Het feit dat hij met een gerechtsdienaar - de jabetnik, die hoger geplaatst was dan de biritsj (vergelijk de vorige brief, nr. 578) - dreigt, wijst erop dat hij het geld van zijn zoon terug wil hebben.

Volgens het Oudrussische wetboek, de Roesskaja Pravda, stonden er 20 grivna's straf op het afhakken van een hand of voet, voor het blindmaken van iemand of voor het vermoorden van je eigen vrouw. Nezjils vergrijp was dus niet licht.

Op de tekening is te zien dat de tekst slechts een deel inneemt van de berkenbast; tussen beide afgebeelde stukken zit nog ongeveer vijftien centimeter die beschreven hadden kunnen worden. De lay-out - met name het aanhouden van een strakke rechterkantlijn - suggereert duidelijk dat de brief nog moest worden bijgesneden. Waarom dat hier niet is gebeurd (en bijvoorbeeld ook niet bij nr. 477, p. 77), weten we niet. Misschien is de brief uiteindelijk niet verstuurd, simpelweg omdat Bratjata er niet achter is gekomen waar zijn zoon zat ...

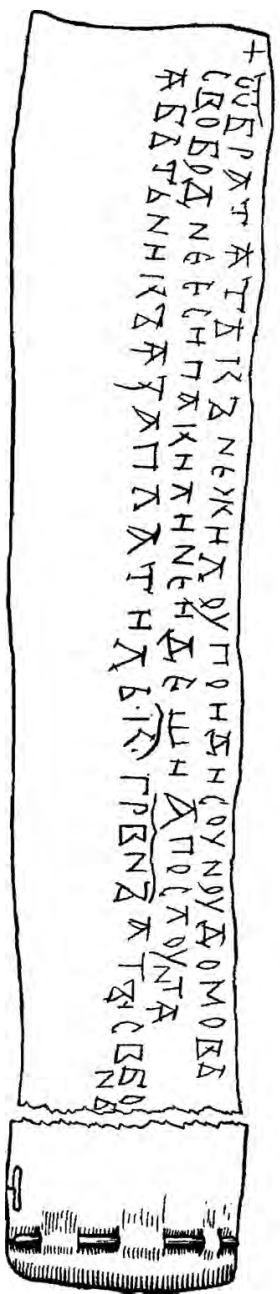


'Ik heb gezien en gehoord wat er is gebeurd'
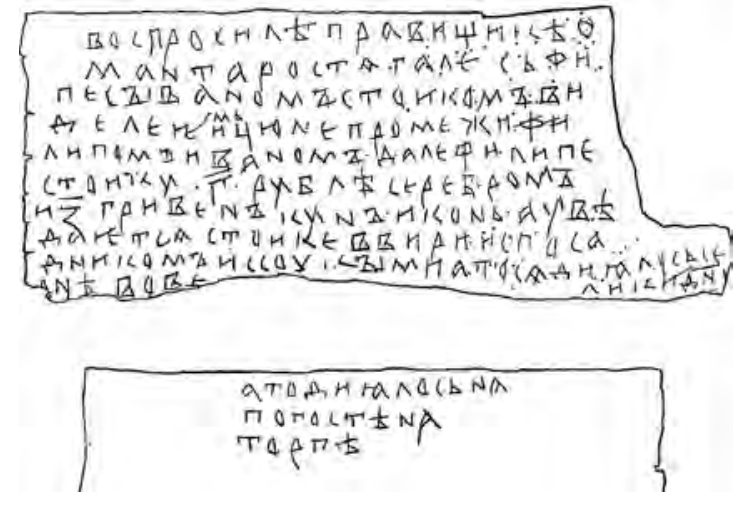

Novgorod nr. 154, ca. 1420-1430

(Binnenkant) De gerechtsfunctionarissen hebben Omant bevraagd naar aanleiding van het feit dat Filipp een rechtszaak is begonnen met Ivan Stojko: "Ik heb gezien en gehoord wat er is gebeurd tussen Filipp en Ivan. Filipp heeft Stojko 3 zilverroebels en 7 grivnakoen en een paard gegeven." Stojko gaat nu onder ede de zaak met de stadhouder en de honderdmannen regelen. Dit heeft vandaag plaatsgevonden, met Pasen.

(Buitenkant) En dit heeft plaatsgevonden in het district, op de markt.

We hebben hier te maken met een helder verslag van een gerechtelijk onderzoek, waarbij de woorden van de getuige Omant in directe rede worden weergegeven. Hij bevestigt dat Filipp geld en een paard aan Ivan (Stojko) heeft gegeven. De schrijver vermeldt op het eind tijd en plaats van het onderzoek.

Een 'honderdman' was oorspronkelijk een militaire rang, maar speelde later een belangrijke bestuurlijke rol in de stad en het land van Novgorod. 
'Dit is wat ik alleen te zeggen heb'

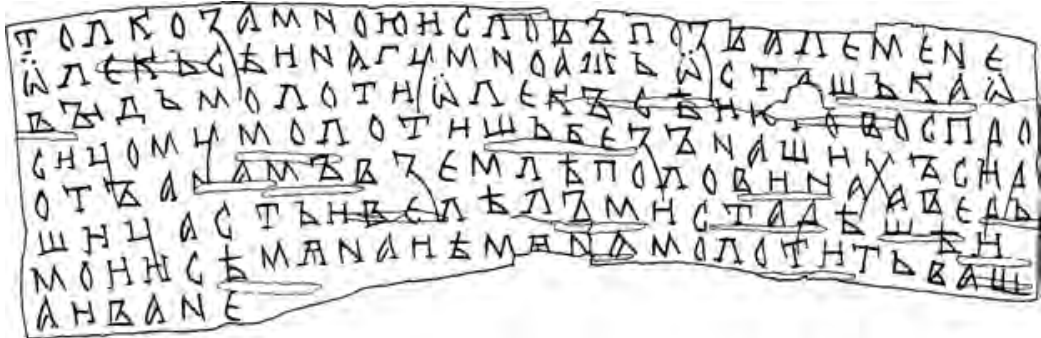

Novgorod nr. 755, ca. 1380-1400

Dit is wat ik alleen te zeggen heb. Oleksej heeft me naar de dorsvloer geroepen omdat Ostasjka de voorjaarsrogge aan het dorsen was. Oleksej vroeg hem: "Waarom ben je aan het dorsen zonder onze boeren? De helft van het land en een deel van het graan is van ons." (Ostasjka:) "Mijn baas heeft me opgedragen om al jullie zaaien voedergraan te dorsen", (d.w.z.) Ivan.

Dit is een ooggetuigeverslag in een juridische context. De onbekende ik-persoon meldt in directe rede wat Oleksej en Ostasjka op de dorsvloer tegen elkaar hebben gezegd.

Taalkundig gezien valt op dat het antwoord van Ostasjka niet wordt ingeleid met woorden als 'En Ostasjka antwoordde.' Toch is het verslag het best te begrijpen wanneer we aannemen dat na de vraag van Oleksej direct het antwoord van Ostasjka volgt. Bovendien wordt directe rede wel vaker niet expliciet ingeleid op berkenbast (vergelijk de vorige brief. nr. 154, en Tver nr. 5, p. 75). Er is verder een subtiele taalkundige reden om aan te nemen dat het laatste woord, 'Ivan', weer uit de mond van de ooggetuige komt, als nadere toelichting bij 'mijn baas'. 
'En ze hebben ook zijn nalatenschap in handen'

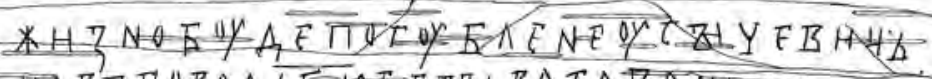

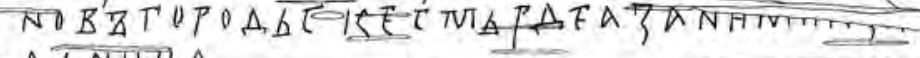

Novgorod nr. 607/562, ca. 1075-1100

Zjiznoboed, een Novgorodse boer, is vermoord door de Sytsjevitsji. En ze hebben ook zijn nalatenschap in handen.

Deze korte, maar volledige tekst bestaat uit twee fragmenten: nr. 562 (de tweede en derde regel), gevonden in 1977, en nr. 607 (de eerste regel), gevonden in 1982 in dezelfde opgraving, maar op een iets andere locatie. Pas later, in 1992, bleek dat de twee stukjes berkenbast een geheel vormen, geschreven in een en hetzelfde handschrift.

Zjiznoboed is een vrije boer (smerd) uit Novgorod die door de 'Sytsjevitsji' is vermoord. Misschien zijn het de bewoners van een plaats Sytsjevo; er bestaat een dorp met die naam honderdvijftig kilometer ten noordoosten van Novgorod. Maar het zou ook om een familie, de 'Sytsjevitsji' geheten, kunnen gaan.

Net als in de twee vorige brieven, nr. 154 en nr. 755, hebben we te maken met een 'brief' zonder afzender en geadresseerde. Ook hier is blijkbaar sprake van een verslag voor een officiële instantie. 
'Ik zit nu dus daar'

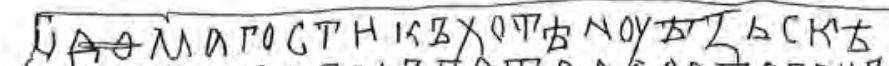

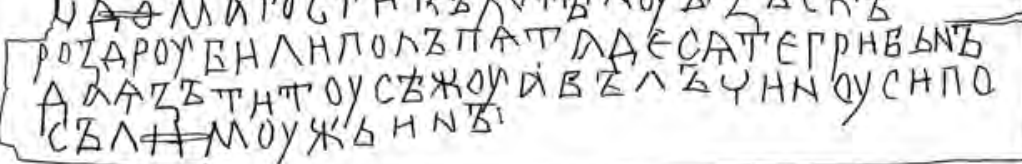

Novgorod nr. 902, ca. 1100-1120

Van Domagost aan Choten. In Ezesk zijn (me) vijfenveertig grivna's toegewezen (om te innen). Ik zit nu dus daar, en stuur een andere man naar Voltsjino.

Niet alleen nr. 902, maar ook twee andere brieven zijn geadresseerd aan Choten, waaronder nr. 912 (zie p. 34). Zijn naam komt ook voor op twee houten cilinders die op dezelfde plek als de drie berkenbastjes zijn opgegraven. Op een van de cilinders wordt hij aangeduid als metsjnik, de functie van verantwoordelijke voor het innen van staatsbelasting in naam van de vorst. De holle cilinders werden gebruikt om door middel van een koord zakken te verzegelen waarin een deel zat van de belasting in natura (dierenhuiden of andere kostbare goederen).

De twee plaatsen die in nr. 902 genoemd worden bevinden zich $240-280 \mathrm{~km}$ ten oosten van Novgorod. Blijkbaar is Domagost naar beide plaatsen gestuurd om belasting te innen, maar duurt het werk in Ezesk zo lang dat hij Choten verzoekt om iemand anders naar Voltsjino te sturen.
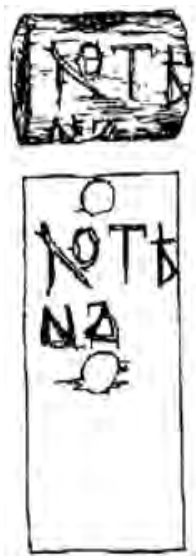


\section{'Draag me niet meer geld op'}

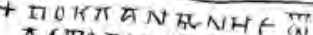

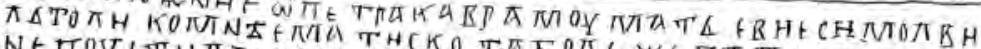

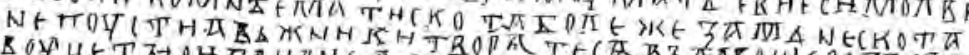

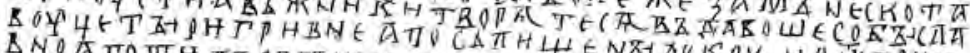

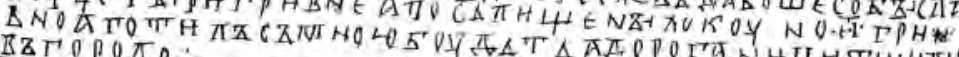
IZTOPOTOO.
}

Novgorod nr. 550, ca. 1180-1200

+ Groet van Petr aan Ovram. Tegen Matej heb je gezegd: "Ik hoef maar zoveel geld te innen. Draag me niet meer geld op." En de nomaden beweren dat ze aan Sbyslav vier grivna's hebben gegeven, en aan vestigingsgeld 15 grivna's. En Gotil zal bij me zijn; de inwoners van Dorogani zijn naar de stad vertrokken.

De brief gaat over problemen met het innen van belastinggeld. Sbyslav schijnt een ondergeschikte te zijn van Ovram, die weer onder Petr staat. Van Petr weten we wie hij was: de bojaar Petr Michalkovitsj, die vaker in berkenbastteksten optreedt (zie p. 162). Men vermoedt dat hij de vader was van Olisej Gretsjin Petrovitsj (zie nr. 502, p. 61, en nr. 549, p. 111).

Petr verwijt Ovram dat Sbyslav volgens 'de nomaden' belasting van hen heeft ontvangen, terwijl Ovram beweert dat hij klaar is met innen. Vervolgens komen ene Gotil en het dorp Dorogani in het Novgorodse land ter sprake. Wellicht hebben deze mededelingen ook betrekking op de belastingperikelen.

Voor 'geld' wordt in nr. 550 en een paar andere brieven het woord skot gebruikt dat ook 'vee' betekent. In het Latijn vinden we dezelfde overeenkomst: pecunia is eveneens afgeleid van 'vee' in de betekenis van betaalmiddel. Het woord skot is overigens etymologisch verwant met Nederlands schat. 
Het testament van Moisej

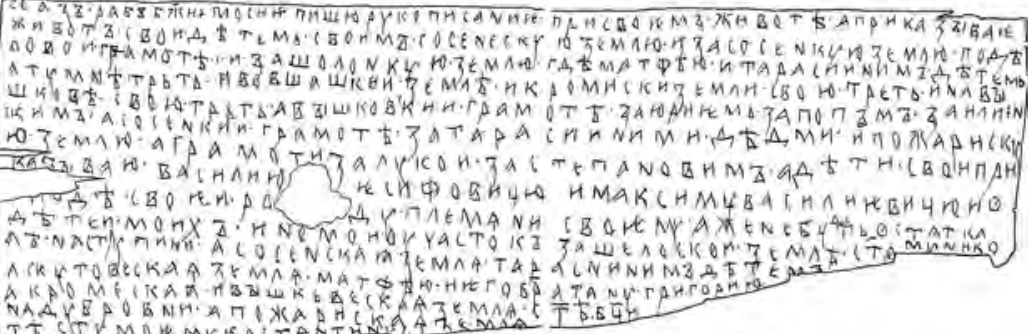

Novgorod nr. 519/520, ca. 1400-1410

(Nr. 519) Hierbij schrijf ik, Gods dienaar Moisej, mijn testament bij leven. Ik vermaak (al) mijn leven aan mijn kinderen, het perceel in Sosna en het perceel achter Sosna, volgens de landscheidingsakte, en het perceel achter de Sjelon, waar Matfej en Tarasija's kinderen en aldaar ik een derde hebben, en mijn derde in het perceel in Vsjaga en het perceel in Kromsko, en mijn derde op Vysjkovo. En de documenten over Vysjkovo zijn bij de priester Joeri van Sint-Ilja, en de documenten over Sosna zijn bij Tarasija's kinderen. En het perceel in Pozjarisjtsja (vermaak ik aan mijn kinderen) en de documenten zijn bij Loeka Stepanov. En mijn kinderen vertrouw ik toe aan Vasili Jesifovitsj en Maksim Vasiljevitsj en aan de heren (van) mijn familie (en) mijn clan. Als mijn kinderen er niet meer zijn (op het moment van mijn dood), dan is mijn aandeel van het perceel achter de Sjelon voor Sint-Nikola op Stroepino, en het perceel in Sosna voor Tarasija's kinderen, en het perceel in Skoetovo voor Matfej en zijn neef Grigori, en het perceel in Kromsko en Vysjkovo voor de Heilige Moeder Gods op Doebrovno, en het perceel in Pozjarisjtsja voor mijn schoonvader Kostjantin. 


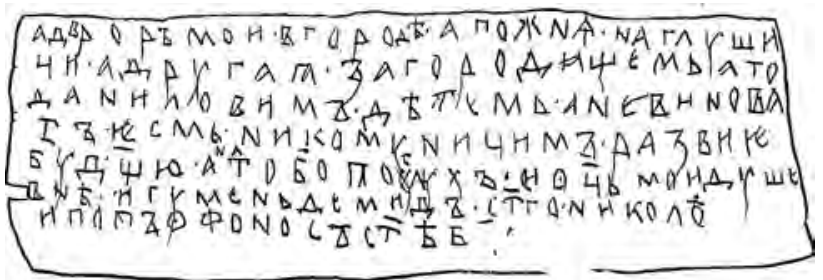

(Nr. 520) En mijn huis in de stad en mijn veld op Gloesjitsa en het andere achter Gorodisjtsje zijn voor Danils kinderen. En ik ben niemand iets verschuldigd behalve mijn ziel aan God. En voor dit is God getuige en mijn geestelijke vader abt Demid van Sint-Nikola en de priester Ofonos van de Heilige Moeder Gods.

Voor deze uitzonderlijke lange berkenbasttekst werden twee forse lappen gebruikt: de eerste meet 47,2 x $16 \mathrm{~cm}$. en de tweede 25,8 x $8,8 \mathrm{~cm}$.

Van Moisej zijn behalve zijn testament ook vier notities op één berkenbast (Novgorod nr. 521) bewaard gebleven. Daaronder bevindt zich het prachtige fragment Mogen jouw hart en jouw lichaam en jouw ziel ontbranden jegens mij en mijn lichaam en mijn aangezicht. Die notities zijn in een ander handschrift dan het testament. Gezien de inhoud en een grammaticale aanwijzing in de tekst is het aannemelijk dat Moisej zijn testament niet zelf heeft opgetekend (zie ook p. 34).

Alle toponiemen in nr. 519 van het testament bevinden zich ten zuidwesten van het Ilmenmeer, rondom de rivier de Sjelon, op enkele tientallen kilometers afstand van Novgorod.

Behalve nr. 519/520 hebben we nog een handjevol andere testamenten op berkenbast (zie nr. 692, p. 110). Een paar hebben duidelijk het karakter van een kladversie. Aangezien dit soort officiële documenten doorgaans op perkament zijn overgeleverd (vergelijk ook nr. 831, p. 31, en nr. 307, p. 80, waar sprake is van verzegelde valse testamenten), kunnen we aannemen dat ook nr. 519/520 een voorversie is van de tekst die uiteindelijk op perkament gesteld moest worden. 


\section{Heren en boeren}

'Wat heb je ons voor beheerder gegeven?'

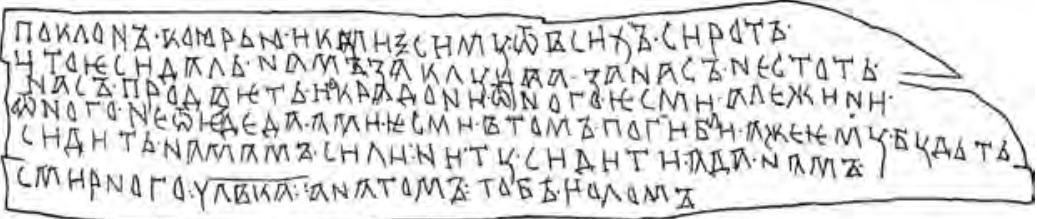

Novgorod nr. 370, ca. 1360-1380

Groet aan Joeri en aan Maksim van alle boeren: Wat heb je ons voor beheerder gegeven? Hij komt niet voor ons op. Hij richt ons te gronde met boetes en we zijn door hem bestolen. En wij kunnen geen kant op en niet bij hem weg! En daarom zijn we geruïneerd. Als hij mag blijven zitten, dan hebben wij niet de kracht om te blijven; geef ons een vreedzame man. En in deze zaak verzoeken we jou nederig.

Met name in de lateren eeuwen van de schrijftraditie op berkenbast komen teksten voor die te maken hebben met het beheer van grondbezit binnen het Novgorodse land. Vaak richten boeren of dorpen zich als collectief tot hun heren in de stad en gaat het om klachten over slechte leefomstandigheden, plotselinge conflicten of mismanagement van lokale opzichters.

Dat laatste is het geval in nr. 370 en het emotioneel gekleurde taalgebruik wijst op een acute situatie, waarbij alle boeren een beroep doen op hun heren. 
'In jouw domein is alleen water te drinken'

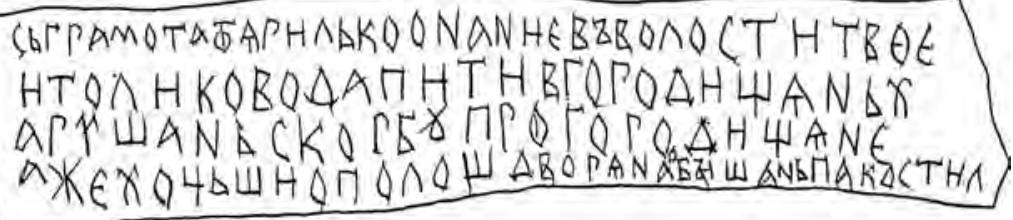

Staraja Roessa nr. 10, ca. 1160-1180

Hier is een brief van Jarila aan Onanija. In jouw domein is alleen water te drinken voor de bewoners van Gorodisjtsje. En de bewoners van Staraja Roessa treuren om die van Gorodisjtsje. Alsjeblieft, dreig de heren met maatregelen zodat ze geen schade toebrengen.

Het dorp Gorodisjtsje dat hier wordt bedoeld lag niet ver ten westen van Staraja Roessa, de vindplaats van deze brief. Jarila brengt Onanija op de hoogte van de hongersnood in zijn gebied en vraagt hem om de verantwoordelijken, die blijkbaar onvoldoende maatregelen nemen, tot de orde te roepen.

Deze brief is een stuk jonger dan de vorige, nr. 370, waarin een collectieve klacht wordt neergelegd. Hier wordt de misstand gecommuniceerd tussen twee individuen, die we overigens verder niet uit andere bronnen kennen. 
'Aan pacht 6 kisten rogge'

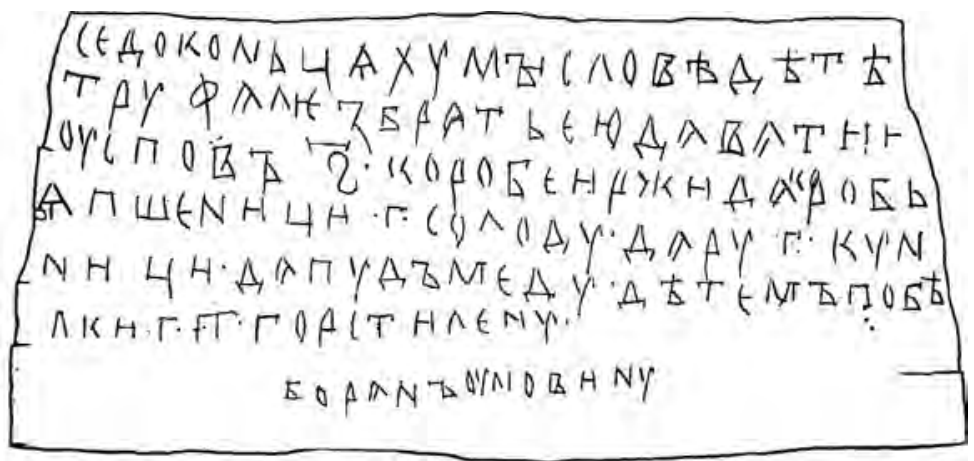

Novgorod nr. 136, ca. 1360-1380

Hierbij zijn overeengekomen de kinderen van Mysl, Troefan en zijn broers, te geven aan pacht 6 kisten rogge, een kist tarwe en 3 mout; aan tribuut 3 martervellen en een poed honing; aan de kinderen ieder een eekhoornvel, 3, en 3 handvol vlas. Een ram bij de eerste oogst.

Het document is een overeenkomst tussen boeren en hun landheer over de betaling van pacht in granen (usop) en tribuut in andere goederen (dar). De naam van de landheer wordt niet vermeld, wel worden zijn kinderen expliciet genoemd, die ook het een en ander moeten krijgen. Het document toont grote overeenkomst met een andere berkenbasttekst uit Novgorod, nr. 406 (p. 158).

Op de afbeelding is te zien dat de laatste regel apart staat en in kleinere letters is geschreven. Hier wordt de ram vermeld. Het zou kunnen zijn dat deze als deel van de overeenkomst in een later stadium, in aanwezigheid van de landheer, is toegevoegd. 


\section{'Bevestig je eigendom over de bijenhof'}

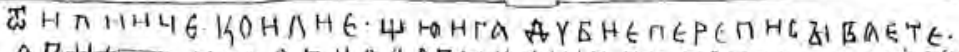

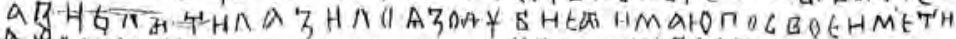

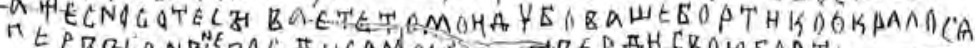

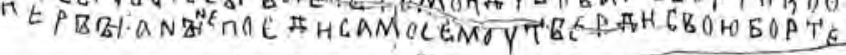

Tver nr. 5, ca. 1300-1320

Van Ilijtsa aan Ilja. Sjoejga overschrijft de tekens op de eiken en hij heeft de honing uit de bijennesten gehaald (en zegt): "Ik neem de eiken met mijn eigen merkteken." Hij kapt het kapteken weg (en zegt): "Het is mijn eik. Jouw bijenhouder heeft als eerste gestolen." En kom nu zelf hierheen; bevestig je eigendom over de bijenhof.

Uit Tver, iets meer dan driehonderd kilometer ten zuidoosten van Novgorod, stammen vijf berkenbastteksten (zie de kaart op p. 20). Deze is de laatste die in Tver is gevonden, in 1996 (voor nr. 2 uit dezelfde stad zie p. 22).

De tekst gaat over wilde bijenhouderij in bossen en over de middeleeuwse (en nog steeds bestaande) praktijk om inkepingen op bijenbomen te maken als teken van eigendom.

Er is een conflict ontstaan dat gerapporteerd wordt aan de eigenaar van de bijenhof, Ilja. De rapporteur, Ilijtsa, is wellicht de opzichter of in ieder geval iemand die ter plekke een zekere verantwoordelijkheid heeft voor het bezit. Hij meldt dat Sjoejga bezig is met het zich toeëigenen van eiken van Ilja en dat Sjoejga vindt dat hij in zijn recht staat. Volgens hem is Ilja als eerste begonnen met het afnemen van eiken met bijennesten. Hoe het ook zij, Ilijtsa verzoekt Ilja actie te ondernemen om zijn bezit veilig te stellen. 
'We willen hem niet; hij is niet van ons'

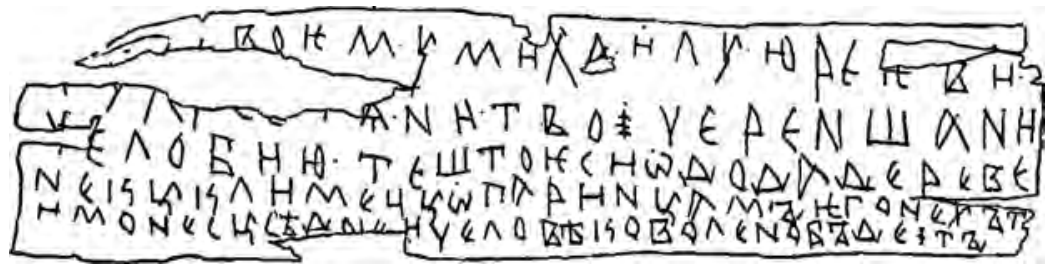

Novgorod nr. 311, ca. 1400-1410

Voor onze heer Michail Joerjevitsj buigen nederig jouw boeren van Tsjerenskoje. Je hebt het dorp aan Klimets Oparin gegeven. We willen hem niet; hij is niet van ons. God en jij beschikken.

De geadresseerde, Michail Joerjevitsj, was telg uit het geslacht van de Misjinitsji (zie p. 166). Op berkenbast figureren onder andere ook zijn grootvader, vader, vrouw en zonen. Uit de kronieken weten we dat Michail tussen 1421 en 1423 gestorven is. In totaal zijn er acht brieven op berkenbast aan hem gericht.

Uit andere bronnen kennen we meerdere dorpen in het Novgorodse land met de naam Tsjerenskoje, allemaal afgeleid van een riviernaam met de betekenis 'zwart'.

De vaker voorkomende slotformule is al behandeld bij de bespreking van Pskov nr. 6 (p. 45). De boeren vertrouwen erop dat Michail terugkomt op zijn beslissing om het dorp te verpachten aan of onder toezicht te stellen van iemand die niet uit hun kring komt, die geen plaatselijke ingezetene is. 
'Er is niets om voor te blijven'

Novgorod nr. 477, ca. 1360-1380

Groet aan Ana van Mikifor vanaf Dorofejs perceel. Wat betreft het veld in Bykovsjtsjina dat je me hebt gegeven, dat neemt Sjoejga af. Het andere (veld neemt) Osipko (af). Er is maar weinig land en ze nemen de velden af. Er is niets aan te verhelpen, er is niets om voor te blijven. Geef me dus die plaats Bykovsjtsjina.

Mikifor beklaagt zich bij Ana dat hem zijn stukken weiland worden afgenomen. Blijkbaar wil hij van haar een bevestiging - een of ander officieel document - waaruit blijkt dat zij hem het land daadwerkelijk heeft gegeven.

De naam Sjoejga komen we ook elders tegen op berkenbast (zie Tver nr. 5, p. 75) en betekent letterlijk 'linkshandige'.

Zoals de tekening laat zien, is het stuk berkenbast niet bijgesneden nadat de tekst erop is geschreven (vergelijk nr. 421, p. 64).

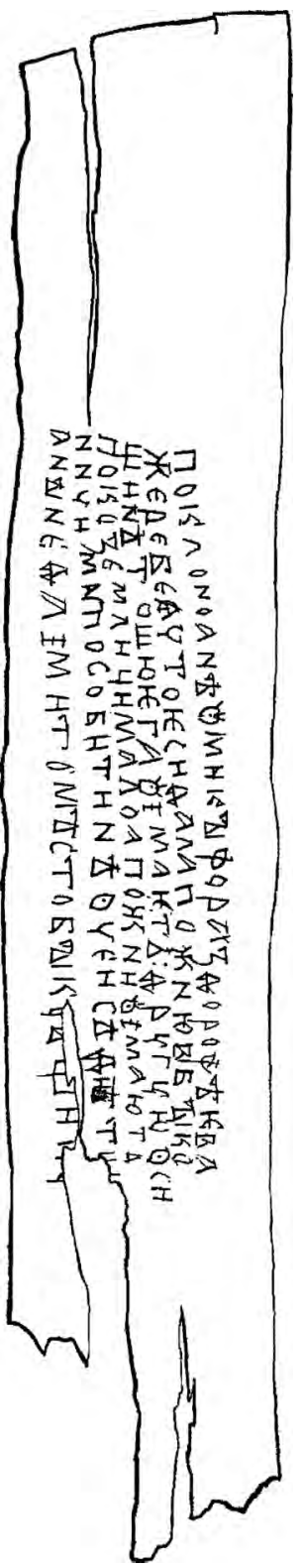


'En wij, heer, zijn geruïneerd'

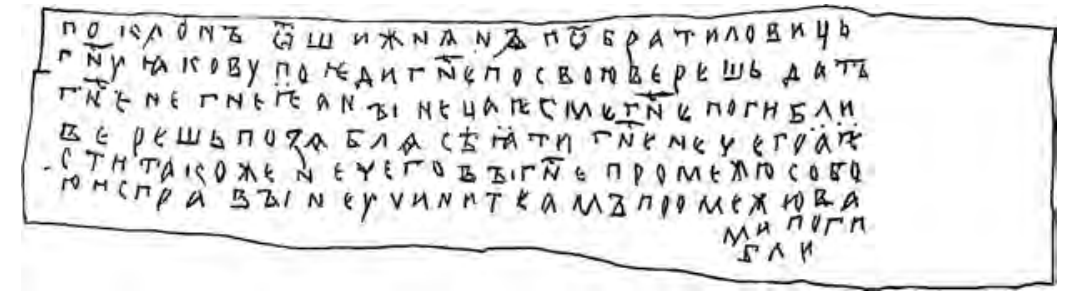

Novgorod nr. 361, ca. 1380-1400

Groet van de bewoners aan de Sjizjnja en van de bewoners van Bratilovitsji aan heer Jakov. Kom, heer, voor je graan opdat het, heer, niet rot. En wij, heer, zijn geruïneerd; het graan is kapot gevroren. Er is niets, heer, om te zaaien en ook niets om te eten. Jullie, heer, regelen onderling niets en wij zijn geruïneerd in jullie midden.

De in deze brief genoemde rivier de Sjizjnja en het dorp Bratilovitsji (nu Ratilovo geheten) liggen meer dan tweehonderd kilometer ten noordoosten van Novgorod.

De collectieve brief is duidelijk een noodkreet en ook een verwijt aan Jakov en de zijnen dat ze nog niet zijn overgegaan tot een gezamenlijke actie tegen de onhoudbare toestand. 
'Heer, jouw aandeel aan rogge is niet groot'

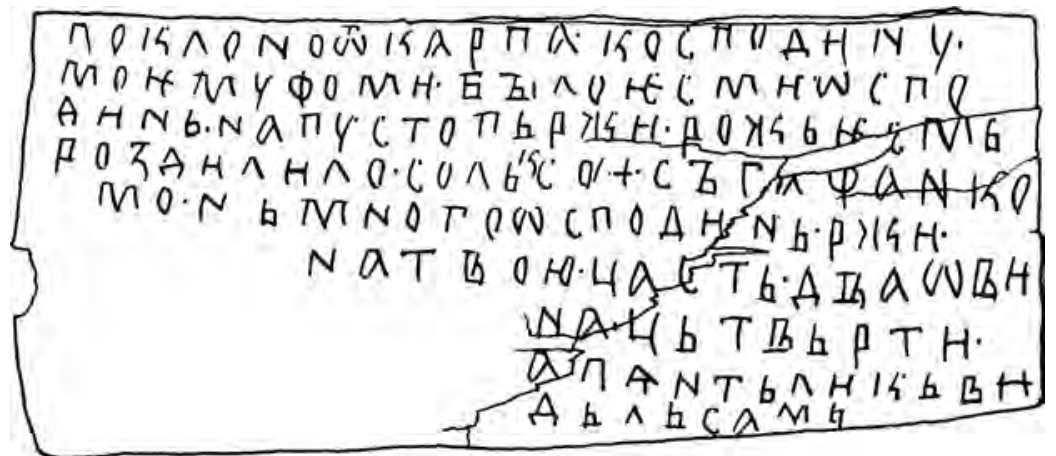

Novgorod nr. 23, ca. 1400-1410

Groet van Karp aan mijn heer Foma. Ik ben, heer, op Poestoperzja geweest; ik heb de rogge verdeeld met Oleksa en met Gafanko. Heer, jouw aandeel aan rogge is niet groot: twee maten van een kwart. En Pjantelik heeft het zelf gezien.

Het niet meer bestaande dorp Poestoperzja is bekend uit andere historische bronnen en lag zo'n honderd kilometer ten westen van Novgorod.

Karp brengt Foma het slechte nieuws dat de opbrengst aan rogge gering is; hij krijgt slechts twee maten uit het kwart van de oogst dat hem toekomt.

De slotzin ('En Pjantelik heeft het zelf gezien') beslaat de laatste twee regels van de brief. De letters zijn wat kleiner dan de rest van de tekst en lijken in de nog beschikbare schrijfruimte te zijn gepropt. Hoewel de gehele brief in een en hetzelfde handschrift is, wijkt de laatste zin grammaticaal af van de voorafgaande tekst. Het ziet ernaar uit dat Karp de opmerking dat er een getuige is geweest bij de verdeling van de oogst, pas in tweede instantie, als een soort postscriptum, heeft toegevoegd; Foma moet niet denken dat de magere opbrengst te wijten is aan malversaties. 
'Hier, heren, verschijnen valse testamenten'

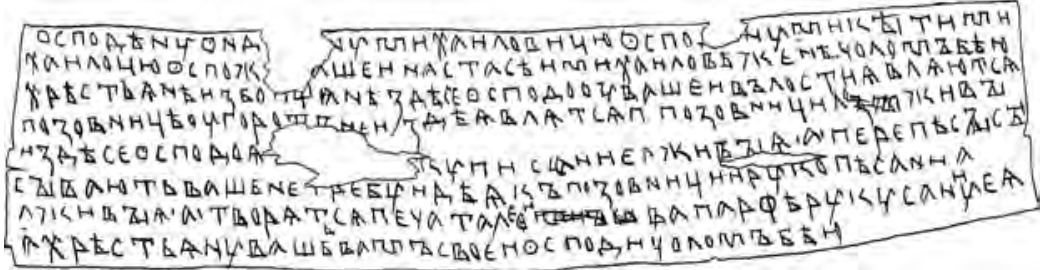

Novgorod nr. 307, ca. 1420-1430

Voor heer Ondrejan Michajlovitsj, heer Mikita Michajlovitsj, onze mevrouw Nastasja, Michails vrouw, buigen nederig de boeren van Izboisjtsje. Hier, heren, in jullie domein Gorotnjaja, verschijnen dagvaardingen. Hier verschijnen valse dagvaardingen. Hier, heren, verschijnen valse testamenten. En jullie Netreboej en diaken kopieren valse dagvaardingen en testamenten. En ze beweren dat Ivan Parfejev de testamenten heeft verzegeld. En jullie boeren buigen nederig voor jullie, onze heren.

Het verzoekschrift om een einde te maken aan het vervalsen van officiële documenten komt uit Izboisjtsje, tweehonderd kilometer ten oosten van Novgorod, en is door iemand geschreven die weinig geletterd was. Er zitten nogal wat grammaticale ongerijmdheden en verschrijvingen in en enkele namen zijn niet goed te plaatsen ('Gorotnjaja'? 'Netreboej en diaken'? 'Ivan Parfejev'?).

De drie geadresseerden behoren tot de Misjinitsji (zie p. 166). Hun vader respectievelijk echtgenoot zijn we al tegengekomen als geadresseerde van nr. 311 (p. 76). 


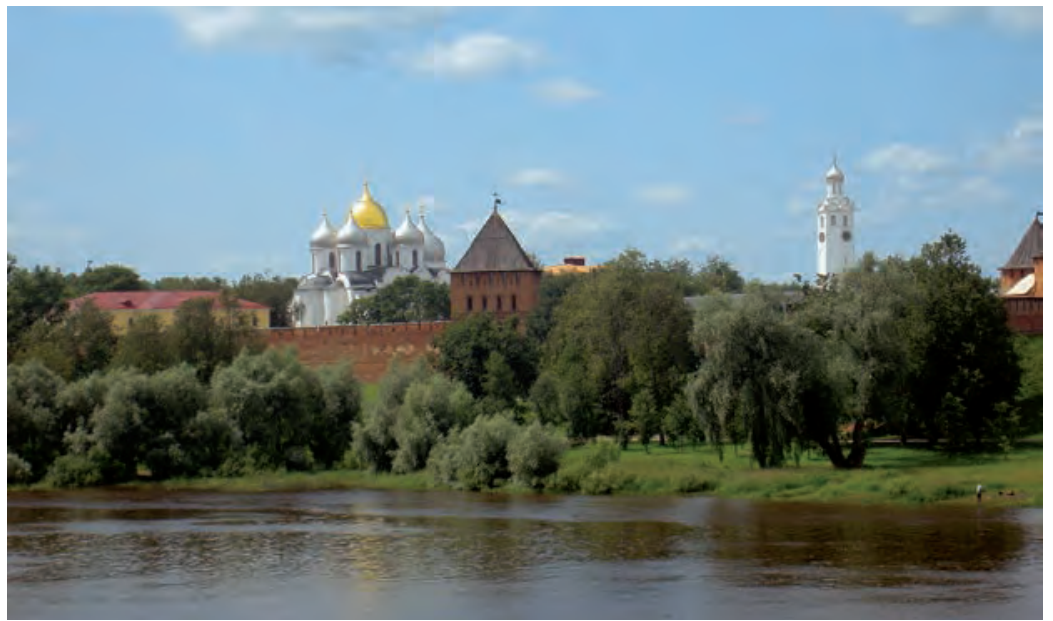

Sofiazijde van Novgorod, met het kremlin, de Sofia-Kathedraal en op de voorgrond de rivier de Volchov

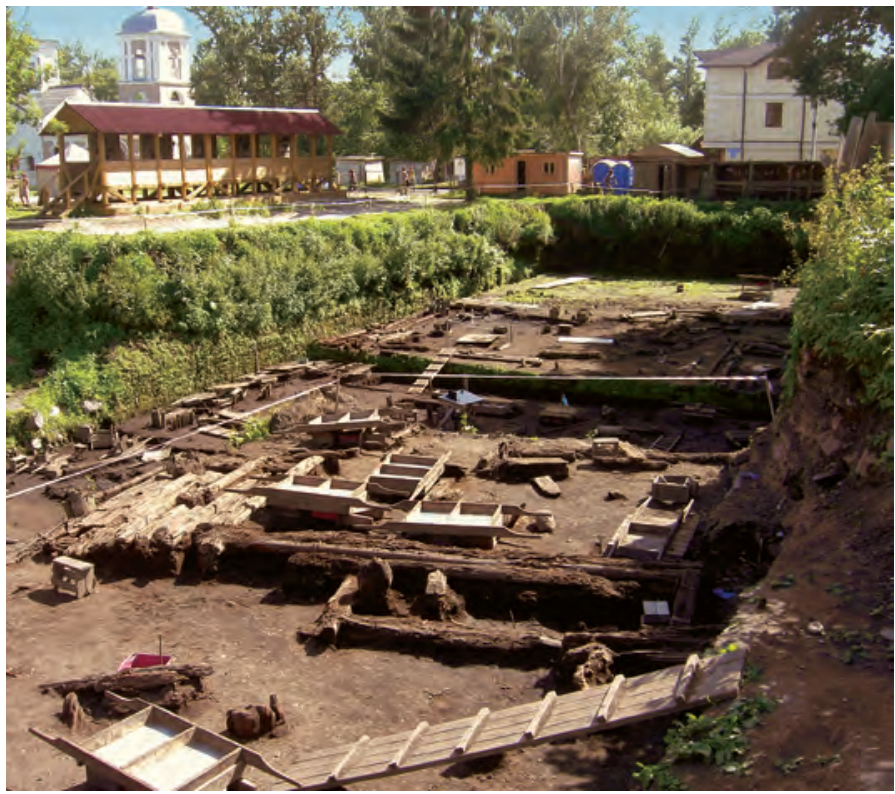

Deel van de Troitski-opgraving zoals deze er in 2009 uitzag

(zie de plattegrond van de stad op p. 16 voor de locatie) 


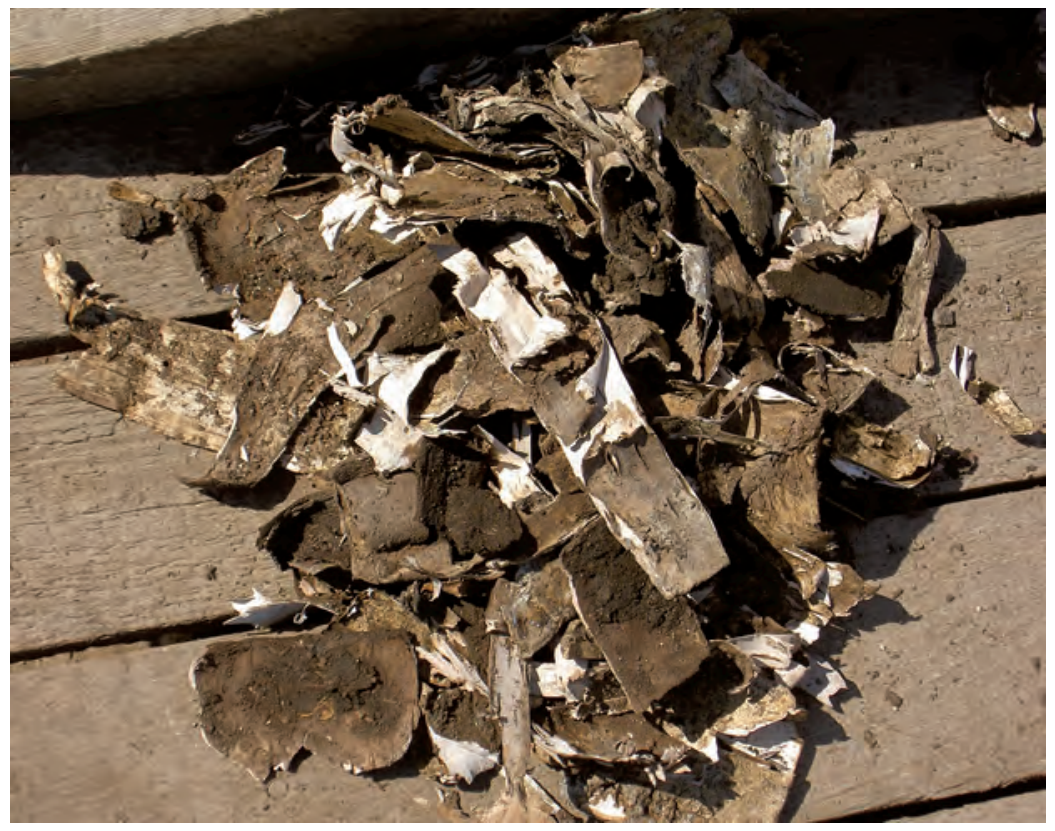

Een doorsnee hoopje berkenbastjes dat wordt opgegraven;

op slechts een fractie van de vondsten bevinden zich teksten

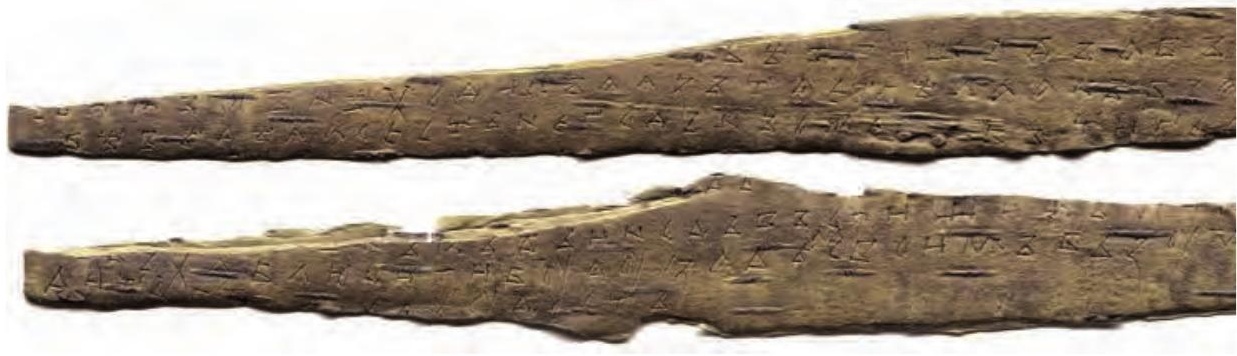




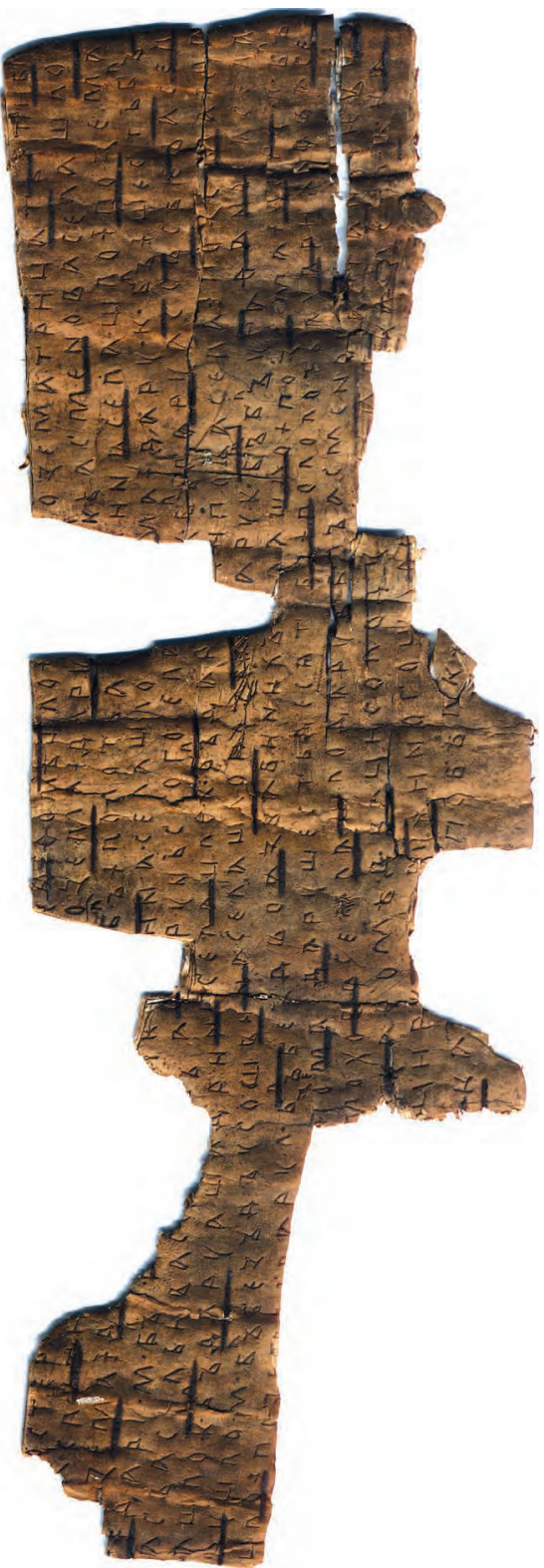

Dit is de eerste berkenbasttekst die in Novgorod is opgegraven, op 26 juli 1951. De tekst dateert uit de periode 1380-1400 en heeft behoorlijke lacunes. Een volledige lezing is daarom niet mogelijk, maar duidelijk is wel dat het gaat om een lijst van inkomsten uit een aantal dorpen. De ontvangers zijn een zekere Timofej (?) en Foma.

In hetzelfde handschrift als nr. 1 is ook nr. 22. Hier vinden we de naam van de afzender: Ljonti. 


\section{Privéleven en het individu}

'En stuur een hemd; ik ben een hemd vergeten'

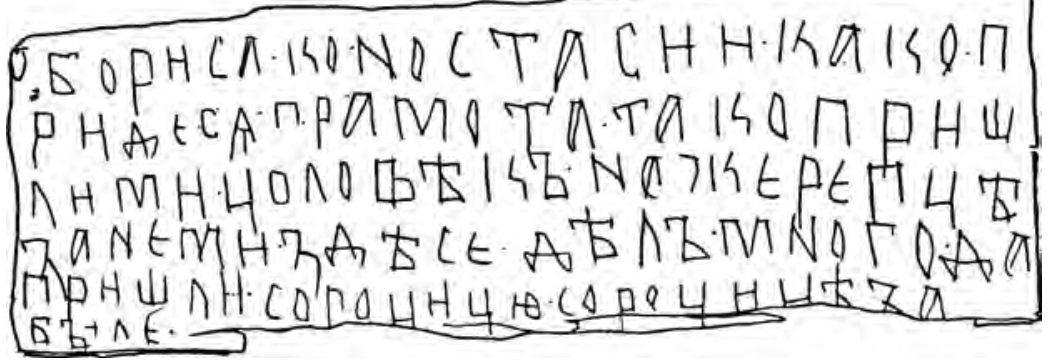

Novgorod nr. 43, ca. 1380-1400

Van Boris aan Nastasja. Zodra deze brief aankomt, stuur me een man op een hengst, want ik heb hier veel te doen. En stuur een hemd; ik ben een hemd vergeten.

Blijkbaar bevindt Boris zich buiten de stad en vraagt hij aan de vrouw des huizes om hem extra mankracht en een hemd te sturen.

Op basis van informatie uit de kronieken wordt vermoed dat de genoemde Boris de stadhouder Boris Vasiljevitsj van Novgorod was. We weten dat deze Boris in 1416 is gestorven.

Op dezelfde plek waar nr. 43 is opgegraven, is ook een fragmentarische berkenbasttekst gevonden (Novgorod nr. 15, ca. 1410-1420) met daarop de naam Ivan en de vadersnaam Borisovitsj. Dit zou wel eens de zoon van Boris en Nastasja geweest kunnen zijn.

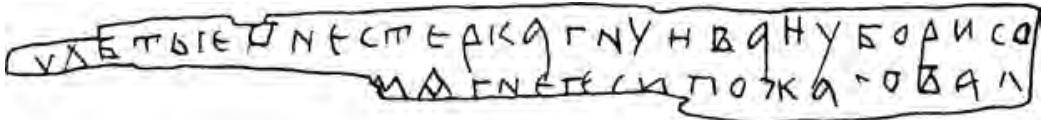

Nr. 43 krijgt een vervolg met brief nr. 49, die hierna aan de orde komt. 
'Mijn Boris is niet meer in leven'

तOKNONZ WNOCTALQHK

EOA HLABХKUGOT HNOHMHA

Novgorod nr. 49, ca. 1410-1420

Groet van Nastasja aan mijn heren, mijn broers. Mijn Boris is niet (meer) in leven. Hoe, heren, gaan jullie voor mij zorgen en voor mijn kinderen?

De vorige berkenbasttekst, nr. 43, krijgt met deze een dramatische wending. Boris is dood en als we uitgaan van de kronieken, dan kunnen we deze tekst, die gevonden is in hetzelfde stadsdeel als de vorige, in het jaar 1416 of vlak daarna plaatsen. Dit is helemaal in overeenkomst met de archeologische datering, ergens tussen 1410 en 1420 .

Op grond van de vorige brief zouden we kunnen denken dat Nastasja een zekere mate van handelingsbevoegdheid en daarmee zelfstandigheid had op het moment dat Boris buiten de stad was. Deze brief geeft echter aan dat Nastasja, samen met haar kinderen - onder wie wellicht Ivan die in nr. 15 wordt genoemd (zie de vorige tekst) - volledig afhankelijk was van haar broers wanneer de heer des huizes niet meer beschikbaar was. 
'Wat neem je me kwalijk?'

Novgorod nr. 752, ca. 1100-1120 (Beginstuk) ... aan jou drie keer. En deze week (of: deze zondag), wat neem je me kwalijk, dat je niet naar me toe bent gekomen? En ik heb je als mijn eigen broer behandeld. Heb ik je werkelijk belast met wat ik (je) gestuurd heb? Voor jou weet $i k$ dat het onprettig is. Als het prettig voor je zou zijn, zou je je uit (andermans) ogen weggerukt hebben en snel gekomen zijn ... (Eindstuk) ... nu ergens op een andere plek. Antwoord me over... Ik zal je nooit verlaten (of: Wil je dat ik je verlaat?) ... Als $i k$ jou belast zou hebben met mijn onverstand en jij me zult bespotten, dan zal God oordelen, en ik.

Op de foto is de berkenbast afgebeeld zoals hij is opgegraven in een kluwen van twee stroken, die het begin en eind van de verscheurde brief vormen; het middenstuk is weg. (Zie p. 83 voor een foto van de tekst in ontvouwde toestand.) De lacune in het begin is te klein om een aanhef te bevatten, hetgeen betekent dat we met een anonieme brief te maken hebben.

De grammaticale vormen geven aan dat de afzender een vrouw en de ontvanger een man is. De inhoud wijst op een soort liefdesbrief; de stijl en met name de woordkeuze duiden op een ontwikkelde, zelfbewuste vrouw, die haar geliefde de mantel uitveegt omdat hij niet op een afspraakje is komen opdagen. In de dreigende laatste 
zin verwijst ze naar zichzelf met 'mijn slechtheid' (hier als 'ik' vertaald); vergelijk bijvoorbeeld het Duitse 'meine Wenigkeit' dat dezelfde functie kan hebben.

$\mathrm{Na}$ de ontdekking in 1993 kreeg de brief aandacht in de internationale pers met aansprekende koppen zoals 'From Russia Without Love' (in The Washington Post) en 'Love in a Wet Climate' (in History Today, waar de brief "Russia's oldest love letter" wordt genoemd).

De ontdekking van nr. 752 wierp ook nieuw licht op een andere brief die al langer bekend was, Novgorod nr. 566 (ca. 1100-1120):

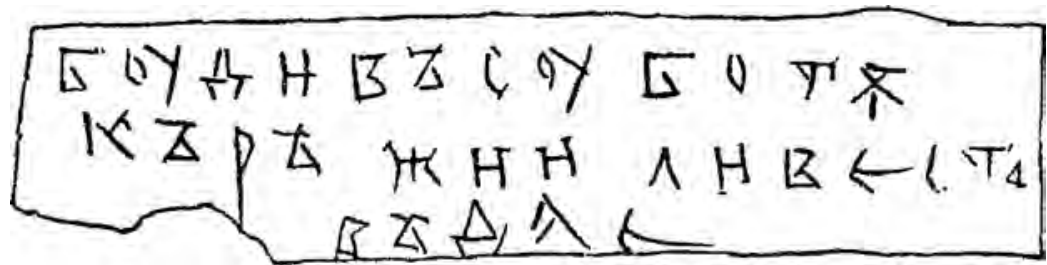

Wees zaterdag bij de rogge of geef bericht.

De tekening laat zien dat we met een volledig tekstje te maken hebben. Iemand wordt gevraagd om op een bepaalde dag naar de 'rogge', d.w.z. het roggeveld te komen. Men zou kunnen denken dat het om een oproep gaat om samen het veld te gaan bewerken. In dat soort gevallen zou echter het ontbreken van een aanhef ("van X aan Y" of iets dergelijks) atypisch zijn voor brieven op berkenbast. Juist de afwezigheid van de naam van de afzender en de geadresseerde duidt op een intiem karakter van de brief, net zoals we in nr. 752 gezien hebben.

In het puur speculatieve domein: nr. 566 en nr. 752 stammen uit dezelfde periode en zijn dicht bij elkaar gevonden. Hebben we te maken met een en dezelfde affaire? 
'Ik wil jou en jij mij'

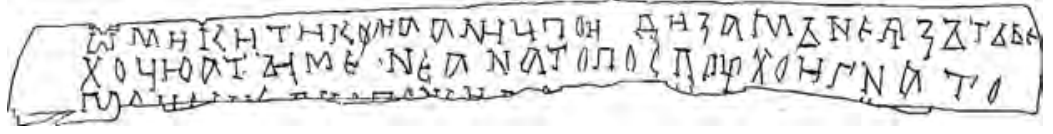

Novgorod nr. 377, ca. 1280-1300

Van Mikita aan Ana. Trouw met mij; ik wil jou en jij mij. En Ignat Moisejev is getuige ...

Terwijl de anonieme schrijfster van de vorige berkenbastbrief, nr. 752 , haar kijk op de liefdesperikelen op subtiele wijze onder woorden probeert te brengen, drukt Mikita zich rechttoe rechtaan uit wanneer hij Ana in deze brief ten huwelijk vraagt.

De tekst is zelfs nog prozaïscher dan hij lijkt, want met het werkwoord 'willen' drukt Mikita niet zo zeer zijn gevoelens uit, maar gebruikt hij een Oudrussische standaardformulering bij huwelijksaanzoeken.

Wat verder opvalt is dat Mikita blijkbaar rechtstreeks, dus niet via de ouders van Ana, een huwelijksaanzoek kon doen. Dat deze praktijk op zijn minst niet standaard was in middeleeuws Rusland, blijkt uit andere bronnen, waaronder berkenbastbrief nr. 955 op de volgende pagina, en ook Novgorod nr. 731 (ca. 1160-1180). Hierin richten ouders zich tot een koppelaarster genaamd Jarina over een mogelijke huwelijksbemiddeling voor hun zoon: Groet van Janka en Seljata aan Jarina. Het kind wil wat je voorstelt. Tegen de tijd van de feestdag wil hij haar. Kom alsjeblieft snel hierheen ... 


\section{'Grote Vlecht, moge zij trouwen met Snovid'}

Novgorod nr. 955, ca. 1140-1160

(Boven) Van Miloesja aan Marena. Grote Vlecht, moge zij trouwen met Snovid.

(Linksonder) Marenka, laat de vulva uit de penis drinken!

(Rechtsonder) Aldus heeft Miloesja gezegd: geef de 2 grivna's van gisteren.

Deze berkenbasttekst is in meerdere opzichten bijzonder. De verdwenen bovenlaag heeft een tekening bevat die is doorgedrukt op de overgeleverde onderlaag. Ze is rechts van de tekst nog vaag zichtbaar: een kruis met aan weerzijden een vrouw en een man, en helemaal rechts op de berkenbast nog een persoon en profil. In relatie tot de tekst lijkt het een voorstelling van een huwelijksceremonie te zijn.

De tekst bestaat uit drie stukjes die elk beginnen met een versierde initiaal. Zoiets is op perkament gebruikelijk, maar hoort niet thuis op het alledaagse schrijfmateriaal berkenbast.

De drie stukjes tekst belichten verschillende facetten van wat een pas afgesloten huwelijksovereenkomst lijkt te zijn. Bovenaan deelt Miloesja aan Marena mee dat het huwelijk tussen Grote Vlecht en Snovid aanstaande is. Deze Snovid zou wel eens dezelfde kunnen zijn als degene die voorkomt in enkele recent opgegraven teksten, waaronder nr. 1009 (p. 52). 'Grote Vlecht' is naar alle waarschijnlijk een individuele bijnaam van een nog ongetrouwde vrouw, die volgens de Russische traditie het haar in één vlecht droeg.

Met het oog op het feit dat Miloesja in het bericht rechtsonder om geld vraagt - de twee grivna's die de dag tevoren zijn overeengekomen - ligt het voor de hand dat zij de koppelaarster is. Gezien de wens die ze in het bericht linksonder uit richting Marenka, namelijk dat het huwelijk vruchtbaar moge zijn, is het aannemelijk dat deze laatste de moeder is van de bruid en dezelfde persoon aan wie 
de brief is gericht. Terwijl Miloesja haar in de aanhef aanspreekt met Marena, gebruikt ze in de vruchtbaarheidsspreuk haar verkleinnaam Marenka.

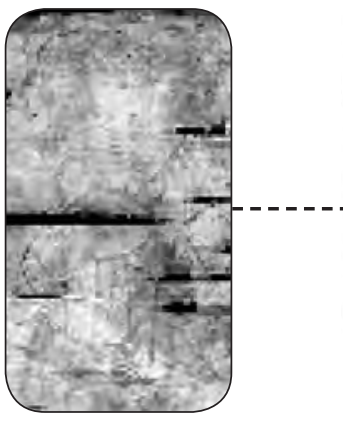

Detailopname van de vrouwelijke figuur (de bruid) links van het kruis
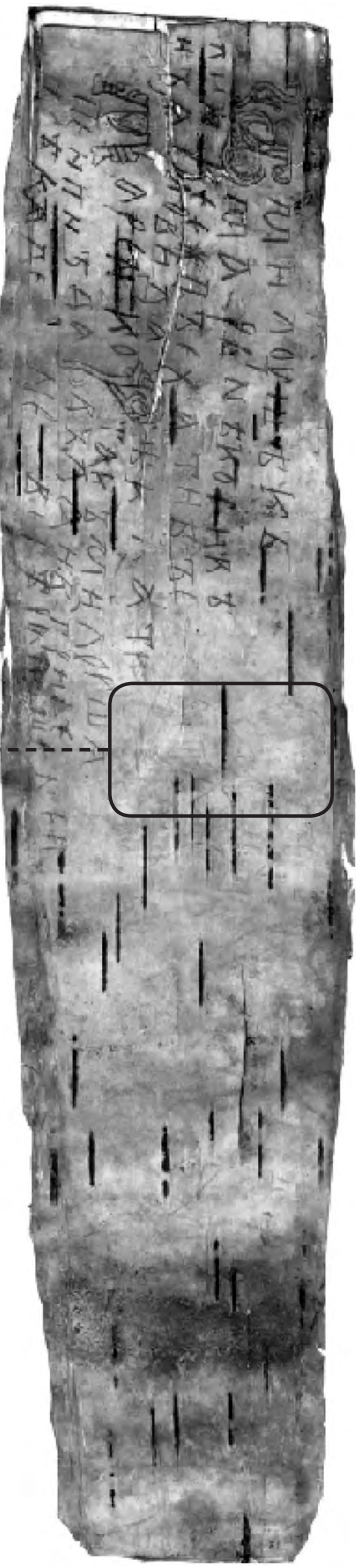


\section{'Waarom schaad je andermans varkens?'}

Novgorod nr. 954, ca. 1100-1120

Brief van Zjirotsjko en van Tesjko aan Vdovin. Zeg tegen Sjiltse: "Waarom schaad jij andermans varkens? Nozdrka heeft dit rondverteld. Je hebt de hele Ljoedin wijk te schande gemaakt. Er is een brief van de andere kant; die was over paarden, dat je hetzelfde hebt gedaan met hen."

De foto geeft deze opmerkelijke brief weer zoals hij in de grond opgerold is gevonden in 2005.

De brief is onder andere uniek omdat verschillende delen van Novgorod genoemd worden (zie de plattegrond van de stad op $\mathrm{p}$. 16): De Ljoedin wijk, aan de

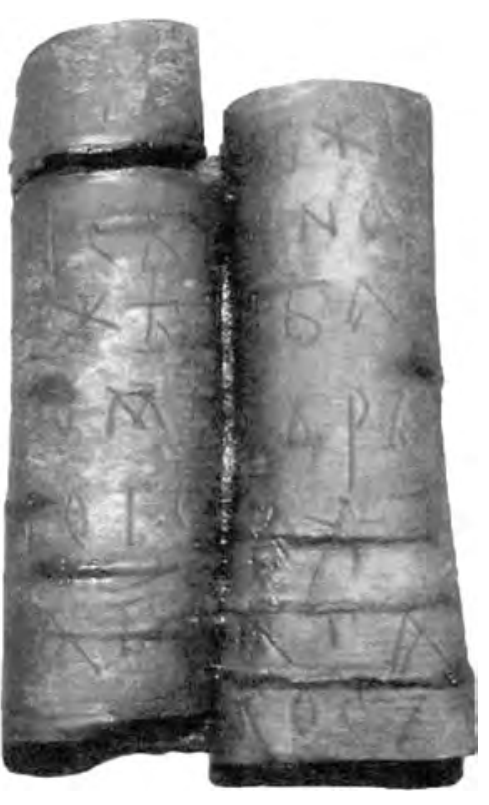
zuidkant van de Sofiazijde van de stad (linkeroever van de rivier de Volchov), waar ook de brief is opgegraven, en 'de andere kant', d.w.z. de Handelszijde aan de rechteroever.

Er zijn verder aanwijzingen in de kronieken dat Nozdrka een vrouw was die ten tijde van de brief woonde in de Nerev wijk, ook aan de Sofiazijde van de stad, maar dan aan de noordkant. Als dat zo is, dan moet de beschuldiging aan het adres van Sjiltse van verschillende kanten van de stad gekomen zijn.

Maar wat houdt de beschuldiging precies in? Wat doet Sjiltse met andermans varkens en blijkbaar ook met paarden? In ieder geval iets ernstigs, iets wat breed bekend en tot schande van zijn hele wijk is. Er bestaan twee interpretaties, die afhangen van de precieze dui- 
ding van het werkwoord dat hier enigszins vaag vertaald is als 'schaden' en waarvan de stam wijst op de betekenis 'een slag toebrengen, stoten, treffen, raken'.

Sjiltses schandalige handelingen met varkens en paarden zouden kunnen slaan op zoöfilie, maar ook op iets anders: het verspreiden van ziekte onder vee (epizoötie) door middel van bezweringsformules. Wanneer we kijken naar het gebruik van het betreffende werkwoord in andere Oudrussische bronnen, dan ligt de eerste verklaring het meest voor de hand. De functionarissen Zjirotsjko en Tesjko uit de Ljoedin wijk instrueren Vdovin, blijkbaar hun ondergeschikte, dat hij actie moet ondernemen tegen de bestiale handelingen van hun wijkgenoot Sjiltse. 
'Ik ben niet jullie zuster, wanneer jullie zo handelen'

I

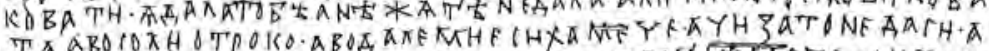

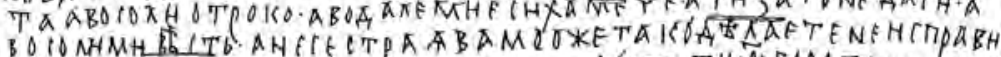

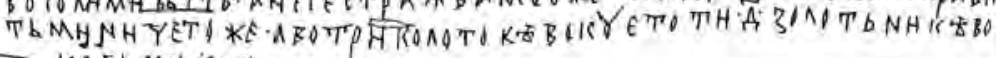
KQNB $4 H \cdot T H F$.

Novgorod nr. 644, ca. 1100-1120

+ Van Nezjka aan Zavid. Waarom stuur je niet wat ik je gegeven heb om te smeden? Ik heb het jou gegeven; $i k$ heb het niet aan Nezjata gegeven. Als ik iets verschuldigd ben, stuur dan een deurwaarder. Je hebt me een stuk stof gegeven; als je het daarom niet geeft, stuur me dan een bericht. En ik ben niet jullie zuster, wanneer jullie zo handelen, wanneer jullie niets voor mij uitvoeren. Dus smeed het om in drie hangertjes, dat wil zeggen de 4 zolotniki in die twee ringen.

Nezjka heeft Zavid gevraagd om twee gouden ringen (ter waarde van vier keer de goudeenheid zolotnik = ca. 4,25 gram) om te (laten) smeden in drie hangertjes (waarschijnlijk als sieraden voor een hoofddecoratie). Zavid levert echter niet en Nezjka vermoedt dat dat komt vanwege het 'stuk stof' dat ze hem eerst had moeten teruggeven.

De familieleden Nezjka, Zavid en Nezjata maken deel uit van een van de oudste netwerken op berkenbast (zie 'Rondom Ivan en Nezjata', p. 160). 
'En nu heeft hij een nieuwe vrouw'

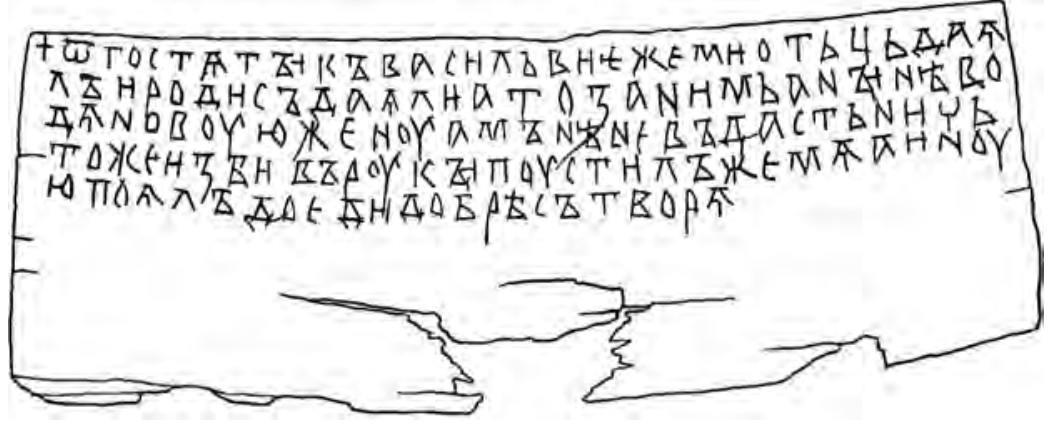

Novgorod nr. 9, ca. 1160-1180

+ Van Gostjata aan Vasilj. Wat vader mij gegeven heeft en de familie heeft gegeven, dat is in zijn bezit. En nu heeft hij een nieuwe vrouw en wil hij mij niets geven. Na de handen geslagen te hebben, heeft hij me weggestuurd en een andere genomen. Kom alsjeblieft. Het is vrij duidelijk dat we hier te maken hebben met het verbreken van een huwelijk, waarbij Gostjata haar bruidsschat niet terugkrijgt. Ze roept nu de hulp in van Vasilj, die waarschijnlijk een familielid is (broer of oom).

Het letterlijk vertaalde 'na de handen geslagen te hebben' moet slaan op het aangaan van een officiële verbintenis, in dit geval tussen Gostjata's ex-man en de 'nieuwe vrouw'.

Het feit dat Gostjata pas in een laat stadium van de ongetwijfeld langer durende gebeurtenis de hulp inroept van Vasilj, doet vermoeden dat de brief van ver buiten Novgorod is verstuurd en dat Gostjata zich in een andere stad bevindt. Het niet-Novgorodse karakter van de taal en de nogal formele spelling van nr. 9 geven verder aanleiding tot de hypothese dat de brief niet door Gostjata zelf, maar door een professionele schrijver op berkenbast is gekrast. 
'En bak het met mate'

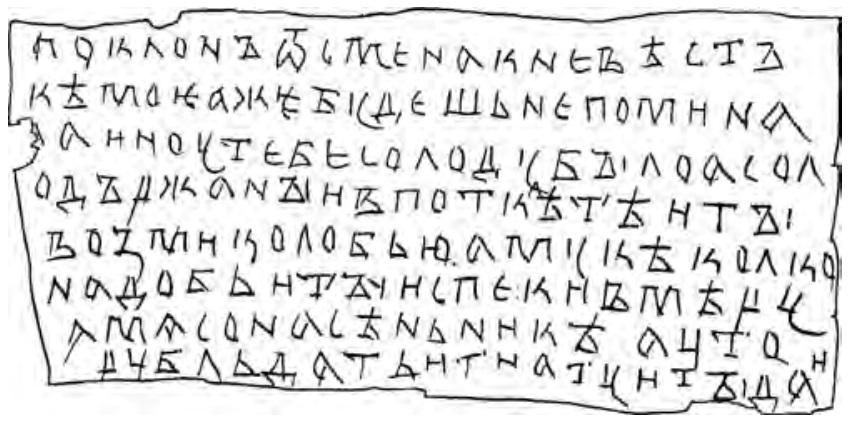

Novgorod nr. 363, ca. 1380-1400

Groet van Smen aan mijn schoondochter. Mocht je het herdenkingsmaal niet gehouden hebben: je had mout en het roggemout is in de kelder. Neem een handvol en zoveel meel als nodig, en bak het met mate. En het vlees is in de voorraadkamer. En wat betreft de roebel die Ignat moet krijgen, geef hem.

Deze brief is samen met een andere opgegraven in een in elkaar opgerolde vorm. Die andere, Novgorod nr. 364, is in hetzelfde handschrift en ook van Smen. Het gaat om een zakelijke brief gericht aan Sidor, die deel uitmaakt van het netwerk rondom Grigori (zie p. 164): ... Wanneer je verkoopt, geef ons dan rogge voor een halve roebel, zoals je anderen (ook) aanbiedt. En de brief is naar jou met mijn knecht. Beide brieven zijn blijkbaar door de knecht nooit afgeleverd bij de twee verschillende geadresseerden.

In nr. 363 herinnert Smen zijn schoondochter aan een te vieren herdenkingsmaal (voor een overledene) en legt uit waar de ingredienten zich bevinden om vleespastei (pirog, een bekend Russisch gerecht) te maken.

Van Ignat, die op het eind van de brief ter sprake komt, wordt vermoed dat hij een telg was van het voorname geslacht van de Misjinitsji (zie p. 166). 
'Kom naar de stad voor aanstaande zondag'

Staraja Roessa nr. 40, ca. 1380-1400

Groet van Oksinja en Onanija aan Rodivon en mijn zuster Tatjana. Kom naar de stad voor aanstaande zondag. Ik ga mijn dochter weggeven en mijn zuster moet bij de ceremonie aanwezig zijn. En ik buig zeer nederig voor mijn heer Rodivon en mijn zuster.

Er is een bruiloft aanstaande en Oksinja nodigt samen met haar man Onanija hun familie in Staraja Roessa uit om daarvoor naar 'de stad', dat wil zeggen naar Novgorod te komen. Tatjana, de tante van de bruid, wordt gevraagd om een ceremoniële rol bij het huwelijksfeest te vervullen.

Hoewel de brief verstuurd is uit naam van beide ouders van de bruid, is feitelijk alleen de moeder aan het woord; de vader Onanija komt na de openingsgroet niet meer in beeld. Oksinja richt zich in eerste instantie tot haar zwager Rodivon, die zowel in de aanhef als in de slotformule als eerste wordt genoemd. In het eigenlijke verzoek spreekt ze over haar zus Tatjana in de derde persoon.

De brief toont inhoudelijk grote gelijkenis met nr. 497 (p. 147), die ook een uitnodiging aan familieleden is om naar 'de stad' te komen. 
'Dood me dan en sla geen acht op Fedor'

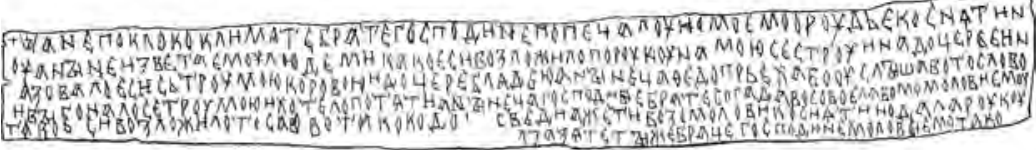

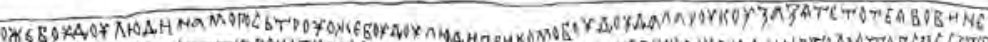
TZG

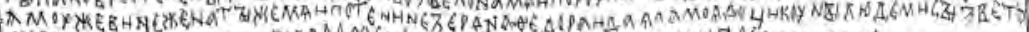

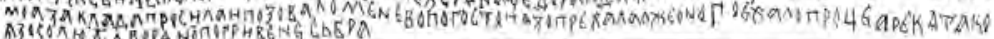

Novgorod nr. 531, ca. 1200-1220

(Binnenkant) + Van Ana een groet aan Klimjata. Broer, heer, treed op in mijn zaak tegen Kosnjatin. Beschuldig hem ten overstaan van getuigen (als volgt): "Nadat jij mijn zuster en haar dochter oplegde om borg te staan, en jij mijn zuster een hoer en haar dochter een slet hebt genoemd, heeft Fedor, toen hij thuiskwam en over deze beschuldiging hoorde, mijn zuster weggejaagd en wilde hij haar doden." En, heer, broer, zeg dan na overleg met Vojeslav tegen hem (Kosnjatin), "Nu je deze beschuldiging hebt voorgelegd, bewijs het." Als Kosnjatin beweert: "Zij stond borg voor haar schoonzoon", dan, broertje, heer, zeg hem dit:

(Buitenkant) "Als er getuigen zijn tegen mijn zuster - als er getuigen zijn ten overstaan van wie ik (lees: zij) borg stond voor mijn schoonzoon, dan ben ik (lees: is zij) schuldig." Jij dan, broer, als je hebt onderzocht welke beschuldiging en borg hij mij ten laste heeft gelegd en er getuigen daarvoor blijken te zijn, dan ben ik voor jou geen zuster en voor mijn man geen echtgenoot. Dood me dan en sla geen acht op Fedor. Mijn dochter heeft het geld gegeven ten overstaan van getuigen, met een publieke verklaring en met een verzoek om een onderpand. En hij (Kosnjatin) heeft mij naar de districtspost geroepen en ik ben gekomen omdat hij is vertrokken met de woorden: "Ik stuur 4 gerechtsdienaren voor de zilvergrivna's." 
Nummer 531 uit Novgorod is de langste brief die is geschreven op één stuk berkenbast. Hoewel het om een juridisch conflict gaat, wordt de tekst in Privéleven en het individu opgevoerd vanwege de emotionele lading en het onverholen taalgebruik in een correspondentie tussen zus en broer.

De tekst is wat zinsbouw en verschillende woordbetekenissen betreft bijzonder ingewikkeld. Een eenduidige lezing is verder moeilijk vanwege de vele schrijffouten die voor een deel gaandeweg weer hersteld worden. De auteur slaat letters en lettergrepen over, wat erop kan wijzen dat de brief onder grote spanning - haast, emotie geschreven is.

Dat Ana zelf de schrijfster is ligt voor de hand, vooral ook vanwege de onverwachte overgang van de derde naar de eerste persoon aan het begin van de tekst op de buitenkant. Ana legt Klimjata eerst haar eigen woorden in de mond ("Als er getuigen zijn tegen mijn zuster ..."), maar schakelt binnen dezelfde zin over op 'ik' (“...ik borg stond ... ben $i k$ schuldig"). Een dergelijke perspectiefwisseling is moeilijk voor te stellen in het geval van een andere briefschrijver dan Ana.

Er bestaan verschillende interpretaties van wat er allemaal precies in deze gecompliceerde brief aan de hand is. Een plausibele verklaring is dat we te maken hebben met een schuld die Ana en haar dochter hebben moeten voldoen aan ene Kosnjatin. De schoonzoon van Ana was de debiteur (en misschien wel de genoemde Vojeslav die ter sprake komt), maar het geld was afkomstig van haar man Fedor, die daar niks vanaf wist. Fedor zet vervolgens Ana op straat en dreigt haar zelfs te doden. Ana vraagt nu haar broer om in te grijpen en aan te tonen dat zij en haar dochter helemaal niet borg stonden voor de schuld en dat ze onder forse dwang van Kosnjatin en onder protest niets anders konden dan het geld betalen. 


\section{'lehodecrvnokpeednidta'}

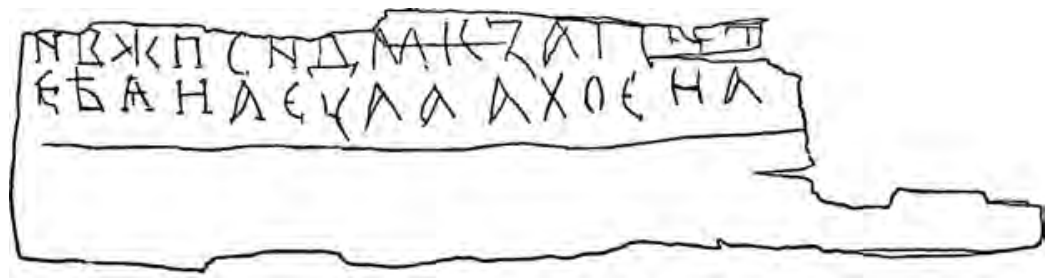

Novgorod nr. 46, ca. $1320-1340$

lehodecrvnokpeednidta egofgsheedmogzgeweils

De vertaling geeft de schrijfrichting van de Russische tekst weer: van boven naar beneden, kolom voor kolom. Er staat dus:

\section{Leeghoofd geschreven, domkop gezegd, en wie dit las ...}

Dit is een van de weinige berkenbastteksten die niet maatschappe-

lijk-functioneel is. Vergelijkbare woordspelletjes vinden we natuurlijk door de eeuwen heen in vele culturen.

Een tekst met de vreemde schrijfrichting zoals in nr. 46 vinden we in Novgorod terug op een verrassende plaats: in een kerk in het Zverin-klooster. Daar bevindt zich op een van de binnenmuren een kleine inscriptie:

$$
\begin{aligned}
& \text { wlaimn } \\
& \text { ezlga }
\end{aligned}
$$

Hier staat dus: Welzalig (de) man. Dit is overigens niet zo maar een tekst, maar het begin van Psalm 1:1 ('Welzalig de man die niet wandelt in de raad der goddelozen'), en tegelijkertijd deel van een hymne die een belangrijke plaats inneemt in de Orthodoxe dienst. 


\section{Leren lezen en schrijven}

\section{'Onfim'}

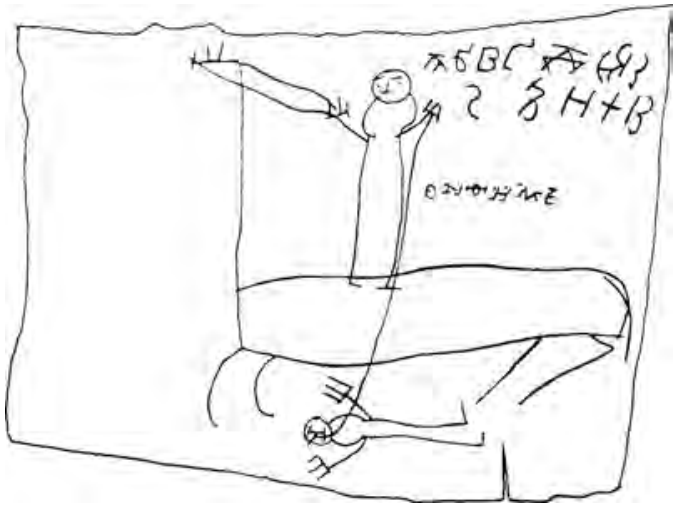

Novgorod nr. 200, ca. 1240-1260

(Rechtsboven, in twee rijtjes) De letters $a$ tot en met $k$ van het cyrillische alfabet.

(Rechtsmidden van de ruiter) Onfim

Onfim is de naam van het jongetje dat deze tekening heeft gemaakt: een ruiter op een paard die met een lans iemand treft die op de grond ligt. In de vakliteratuur wordt gespeculeerd of de ruiter een zelfportret is van Onfim.

We zijn Onfim al tegengekomen in het Voorwoord, waar Novgorod nr. 202 is afgebeeld (p. 7): een tekening van twee personen. De tekst daarnaast is niet helemaal duidelijk: schulden te nemen van Dmitr (?).

Onfims 'oeuvre' op berkenbast bestaat in totaal uit zeventien stukjes. Op twaalf daarvan vinden we tekeningen, al dan niet voorzien van tekst. Op de andere vijf heeft hij alleen maar iets geschreven. Op basis van de stijl van de tekeningen en het soort teksten wordt vermoed dat Onfim zes of zeven jaar oud was. Hij leerde schrijven door het alfabet te oefenen, lettergrepen te herhalen en stukjes bekende tekst (psalmen) te reproduceren. 
'Ik ben een beest'
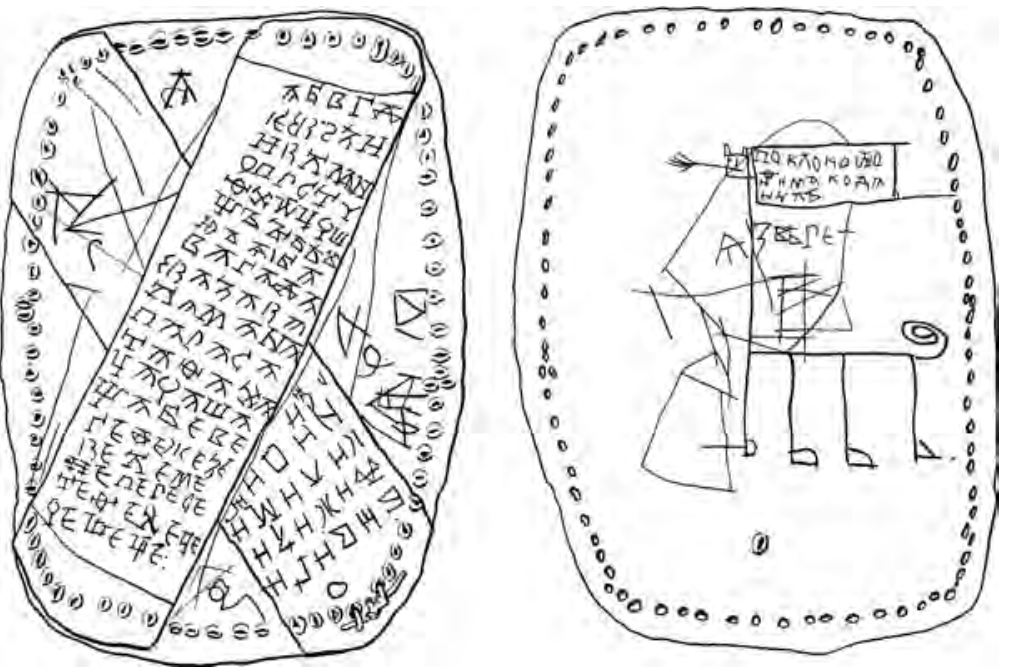

Novgorod nr. 199, ca. 1240-1260

(Binnenkant) De letters van het cyrillische alfabet en reeksen lettergreepoefeningen: ba va ga da enz., be ve ge de enz., bi vi gi di enz.

(Buitenkant, in kader) Groet van Onfim aan Danila.

(Buitenkant, onder kader) Ik ben een beest.

Aan de gaatjes aan de randen kun je zien dat nr. 199 oorspronkelijk de bodem van een berkenbastmandje was. Het werd blijkbaar niet meer gebruikt en de bodem diende vervolgens als oefenmateriaal.

De tekening aan de buitenkant stelt een beest voor met een lange nek, úítstekende oren en een gekrulde staart. In de bek van het beest steekt een pijl met veren aan het uiteinde; het zou ook een vuurspuwende bek of lange tong kunnen zijn.

Als je de verzameling tekeningen van Onfim bekijkt, dan bestond zijn belevingswereld voornamelijk uit paarden, krijgers, pijlen en gevloerde vijanden. Iets van alle tijden. 


\section{'Heer, help Uw dienaar Onfim'}

Novgorod nr. 203, ca. 1240-1260

Heer, help Uw dienaar Onfim.

Onfim leerde niet alleen schrijven door te oefenen met het alfabet, maar ook met kleine stukjes tekst. Hier lezen we een bekende

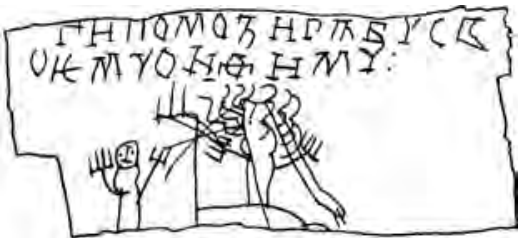
religieuze spreuk boven een chaotische tekening van een persoon naast een paard met een ruiter erop. In een andere berkenbasttekst (Novgorod nr. 207), zonder tekening, oefent Onfim met wat frasen uit een psalmboek. Op weer een ander berkenbastje van zijn hand (Novgorod nr. 331) lezen we fragmenten van Psalm 27:3 en 6:2.

Oefenen met het alfabet en religieuze teksten deed men niet alleen op berkenbast, maar ook op houten wastafeltjes, waarvan er in Novgorod een tiental gevonden zijn. De bekendste is de zogenaamde Novgorodse Codex, die in 2000 is gevonden en uit een set van drie houten tabletten bestaat die vroeger met koorden aan elkaar hebben gezeten en samen een 'boekje' vormden. Het middelste tafeltje kon aan beide zijden beschreven worden, terwijl de andere twee met ieder slechts één waszijde de 'kaft' vormden. Op de vier 'pagina's' zijn in het begin van de elfde eeuw vele teksten geschreven en weer uitgewist. Op de bovenste laag lezen we Psalm 75, 76 en 67:4-6.

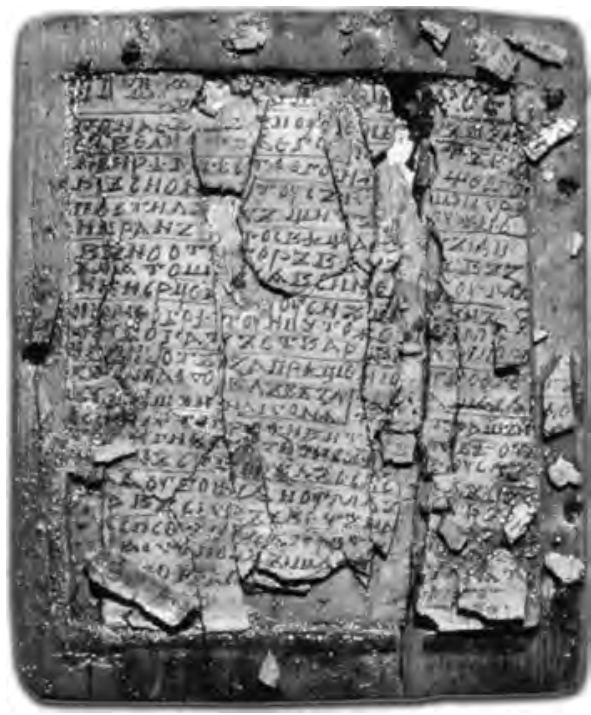


Nog meer Onfim

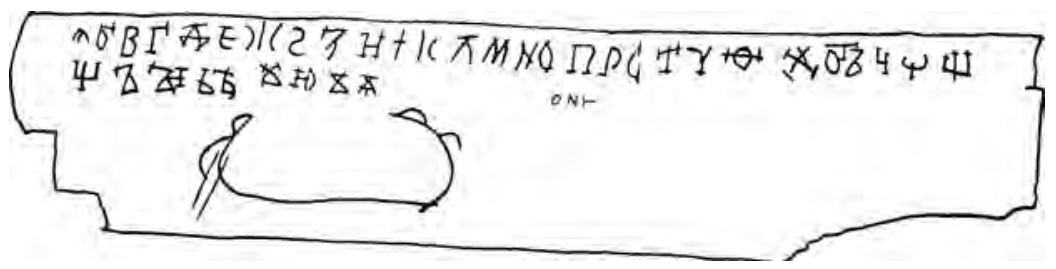

Novgorod nr. 205, ca. 1240-1260

De letters van het cyrillische alfabet, gevolgd door $O n[f]$ in kleinere letters in het midden van de tweede rij.

Het is duidelijk dat 'On' en de niet afgemaakte letter ' $\mathrm{f}$ ' het begin van Onfims naam vormen. Daaronder zien sommige onderzoekers de contouren van een schip met roeispanen.

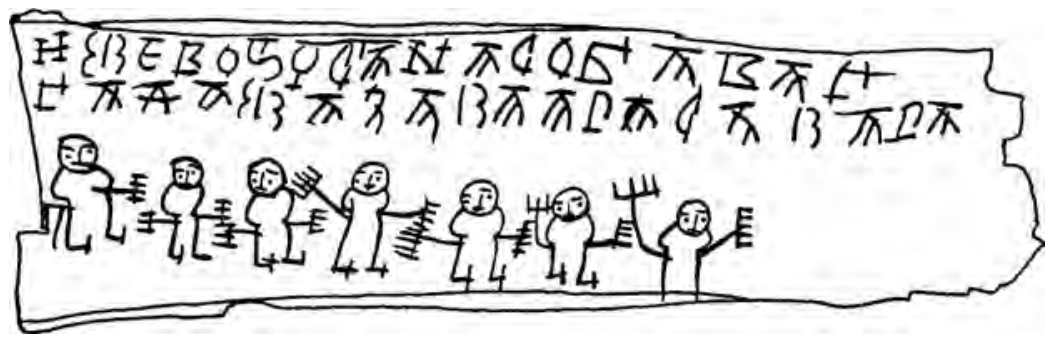

Novgorod nr. 206, ca. 1240-1260

Enkele woorden, gevolgd door de lettergreepreeks ba va ga enz.

De woorden voorafgaand aan de lettergrepen zijn niet helemaal duidelijk. In het cyrillische schrijfsysteem werden letters ook gebruikt om getallen aan te geven en het is goed mogelijk dat dat ook hier het geval is. Een aantal letters zou dan samen het jaartal 1263 kunnen vormen, hetgeen overeenkomt met de archeologische datering. 
We hebben overigens nog meer alfabetoefeningen op berkenbast behalve die van Onfim. De oudste stamt al uit de vroegste periode, Novgorod nr. 591 (ca. 1030): $a b v g d$ enz. Er is ook een wastafeltje uit de twaalfde eeuw overgeleverd met ingekraste letters aan de (houten) zijkanten. Op een van de kanten staat van boven naar beneden de schijnbaar chaotische lettervolgorde Б Ж К П ФШ Ю.
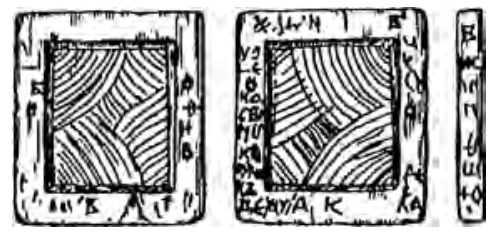

Echter, als we kijken naar de rijen van vijf letters die Onfim op de binnenkant van nr. 199 noteert (zie p. 102), dan blijkt de volgorde grotendeels overeen te komen met de tweede kolom letters. Dit betekent dat het wastafeltje tot een polyptiek behoorde dat uit vijf delen moet hebben bestaan. Wanneer alle delen rechtop naast elkaar staan dan lees je op de rug van de wastafeltjes van links naar rechts, in rijen van vijf, de letters van het alfabet:

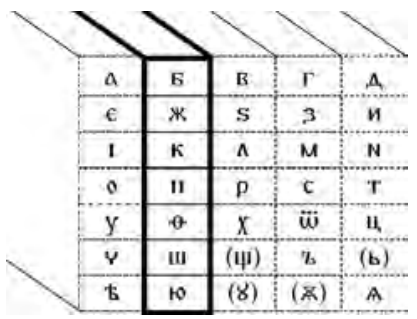




\section{'Laat hen leren lezen en schrijven'}

Novgorod nr. 687, ca. 1360-1380

... koop vet voor jezelf en (koop) voor de kinderen kleren ... laat (hen) leren lezen en schrijven, en de paarden ...

Deze fragmentarisch overgeleverde brief is ongeveer een eeuw jonger dan de schrijfoefeningen van Onfim (zie de zojuist behandelde teksten). De afzender geeft opdracht aan de ontvanger - een man die buiten de stad is en zijn vrouw aanschrijft? - om een aantal huishoudelijke taken uit te voeren: er moet vet worden gekocht, er moet iets gebeuren met de paarden, en de kinderen moeten kleren krijgen. Tussen deze alledaagse beslommeringen staat ook dat de kinderen moeten leren lezen en schrijven.

Blijkbaar was dat laatste voor de periode waarin de brief is geschreven geen abnormale aangelegenheid, waar een aparte brief aan gewijd moest worden en verdere instructies noodzakelijk waren. De geadresseerde wist kennelijk wat er moest gebeuren om de kinderen aan het lezen en schrijven te krijgen.

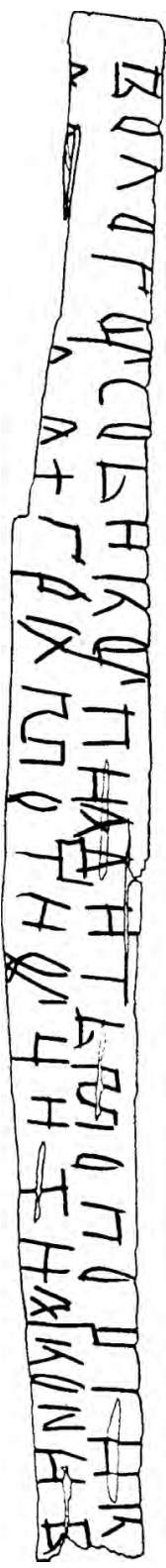




\section{Kerk en religie}

'De abt liet me niet gaan'

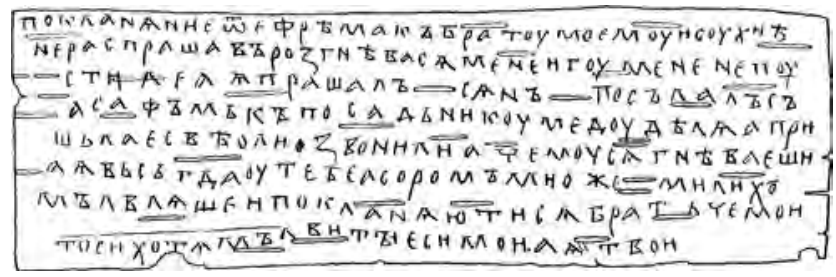

Novgorod nr. 605, ca. 1100-1120

Groet van Efrem aan mijn broer Isoechija. Zonder nagevraagd te hebben ben je boos geworden. De abt liet me niet gaan, en ik heb verlof gevraagd, maar hij heeft me samen met Asaf naar de stadhouder gestuurd om honing. En we kwamen samen aan toen er al geluid werd. Waarom ben je dan boos? Ik ben altijd bij je. Maar het is beschamend voor me dat je kwaad tegen me spreekt. En toch groet $i k$ je, mijn dierbare broer, hoewel je zo spreekt. Jij bent de mijne en ik ben de jouwe.

Berkenbast werd doorgaans niet gebruikt om religieuze teksten, waaronder liturgische ten behoeve van de kerkdienst, op vast te leggen; die moesten langer meegaan en daarvoor diende perkament. Monniken en priesters gebruikten echter in de dagelijkse praktijk net als leken berkenbast als communicatiemiddel, kladversie of persoonlijk memo.

Deze brief is duidelijk afkomstig van een monnik (en waarschijnlijk gericht aan een medebroeder), wat niet alleen de inhoud verraadt, maar ook het taalgebruik - een mix van lokale en Kerkslavische kenmerken. Efrem verwijt Isoechija dat hij ten onrechte kwaad op hem is geworden; hij kon er niets aan doen dat hij te laat was voor een afspraak met hem. Overigens bestaan er meer interpretaties van het slot van de tekst ('hoewel je zo spreekt ... ik ben de jouwe'), dat taalkundig verschillend uitgelegd kan worden. 
'Zorg dat hij snel gezouten en verse vis levert'

+ TOKNMNANHE

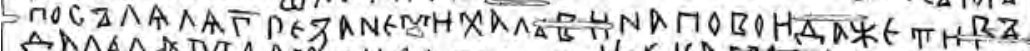

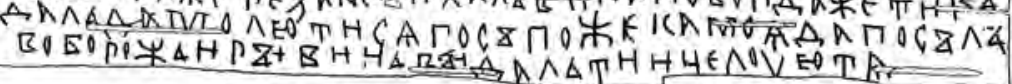

Novgorod nr. 682, ca. 1160-1180

+ Groet van Charitanija aan Sofija. Wat betreft de 3 rezana's die ik Michalj heb gestuurd voor de sluier, zorg dat hij die geeft. Ook vraag ik je, mevrouw: zorg dat hij snel gezouten en verse vis levert. Ik groet je.

Terwijl de vorige brief, nr. 605, van de ene monnik aan de andere is gestuurd, gaat het hier waarschijnlijk om een briefwisseling tussen twee nonnen. Hierop duiden verschillende zaken: de namen van de afzender en geadresseerde; de vermelding van een sluier; en de slotformule die als afsluitende groet haar oorsprong vindt in het geestelijke milieu (in het modern Russisch heeft het betreffende werkwoord de betekenis 'kussen').

De brief is gevonden in de Troitski-opgraving in de Ljoedin wijk (zie de kaart op p. 16). Een van de oude straten die dit gebied doorkruiste was de Nonnenstraat (Tsjernitsyna), zo genoemd vanwege het nabijgelegen Sint-Barbaraklooster. Meerdere brieven, waaronder deze en de volgende (nr. 717 en nr. 692), en ook fragmenten van liturgische teksten, worden met het klooster in verband gebracht. 
'En ik heb veel zorgen over de nonnen'

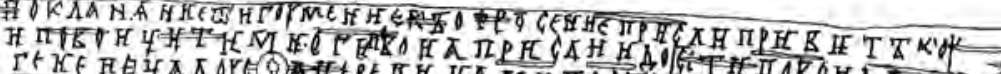

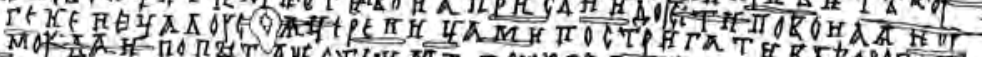

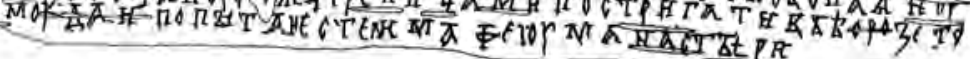

Novgorod nr. 717, ca. 1160-1180

Groet van moeder-overste aan Ofrosenja. Stuur een windsel en sluiers. Als je veel sluiers hebt, stuur dan maximaal vijf sluiers. En ik heb veel zorgen met de nonnen; ze moeten spoedig gewijd worden. Ga daarom navragen of Mafej in het klooster is.

Deze brief wordt net als de vorige (nr. 682) en de volgende (nr. 692) verbonden met het nonnenklooster Sint-Barbara. De precieze betekenis van het woord dat hier vertaald is als 'windsel', is niet helemaal duidelijk. Waarschijnlijk gaat het om een specifiek kledingstuk voor nonnen dat ergens omheen gewonden of gesnoerd moest worden.

Uit de kronieken weten we wie rond de tijd dat nr. 717 werd geschreven, overste waren van het nonnenklooster: Anna, Maremjana, Christina en Varvara (Barbara). Een van hen zal de afzender van de brief geweest zijn.

Een mogelijke verklaring waarom Mafej opgetrommeld moet worden, is dat hij de priester is die de wijding van de nonnen moet voltrekken. 
'Moge hij het gebruiken ter nagedachtenis aan mij'

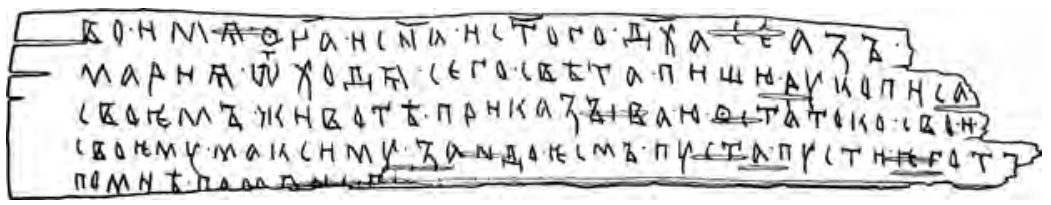

Novgorod nr. 692, ca. 1400-1410

In de naam van de Vader en de Zoon en de Heilige Geest. Hierbij schrijf ik, dienares Gods Marija, scheidend uit dit leven, mijn testament bij leven. Ik vermaak mijn nalatenschap aan mijn ... Maksim, want ik ben ledig. Moge hij het gebruiken ter nagedachtenis aan mij.

We zijn in dit boek al eerder een testament tegenkomen, namelijk dat van Moisej (nr. 519/520), dat in de rubriek Recht en bestuur is behandeld (zie p. 70). Het testament van Marija wordt hier onder Kerk en religie opgevoerd omdat ze waarschijnlijk een non was. Hierop wijst onder andere de omstandigheid dat de brief dicht in de buurt van het Sint-Barbaraklooster is gevonden (vergelijk de vorige brieven nr. 682 en nr. 717).

Marija was 'ledig', dat wil zeggen kinderloos, en ze had blijkbaar weinig bezit; het wordt niet gespecificeerd en is slechts ter nagedachtenis aan haar bedoeld. Tegen deze achtergrond is het denkbaar dat de lacune in 'aan mijn ... Maksim' opgevuld kan worden met het woord voor 'priester'. 
'Schilder me 2 zesvleugelige engelen'

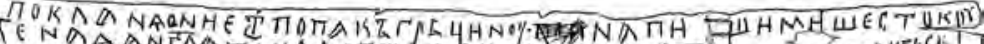

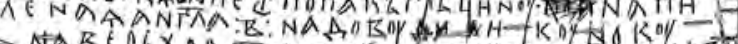

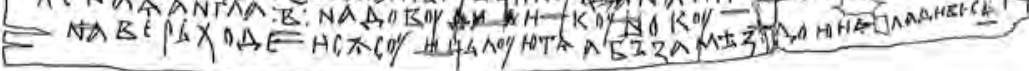

Novgorod nr. 549, ca. 1180-1200

Groet van de priester aan Gretsjin. Schilder me 2 zesvleugelige engelen op twee iconen, voor boven de deïsis. Ik groet je. God staat garant voor de beloning of anders worden we het wel eens.

De 'deïsis' is een icoon of iconengroep die het kernstuk vormt van de iconostase en waarop Christus wordt geflankeerd door Maria en Johannes de Doper.

In nr. 502 (p. 61) zijn we (Olisej) Gretsjin al tegengekomen als gerechtsdienaar. Hier treedt hij op als iconenschilder, zoals we hem

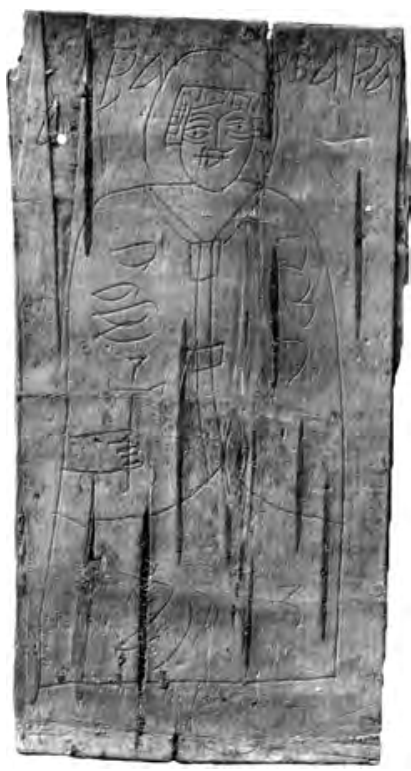
ook kennen uit de Eerste Novgorodse Kroniek waar hij onder het jaar 1196 wordt vermeld als Gretsjin Petrovitsj, d.w.z. Gretsjin, zoon van Petr: "In datzelfde jaar liet aartsbisschop Martoeri de kerk van de Heilige Moeder Gods bij de poort beschilderen, en de schilder was Gretsjin Petrovitsj”.

Overigens vinden we ook een iconografische voorstelling op berkenbast: Novgorod nr. 915-I (ca. 1030), waar op de ene kant de Heilige Barbara is afgebeeld en op de andere Christus. Op beide kanten vinden we ook korte inscripties, waaronder de naam Varvara. Vermoed wordt dat het stukje berkenbast een soort van talisman was. 


\section{Berkenbastboekje}

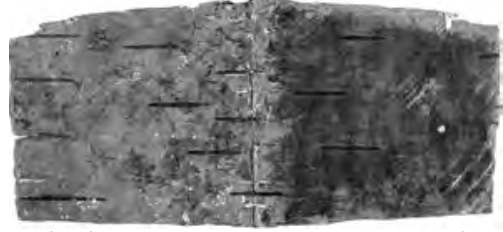

2 achterkant

1 voorkant

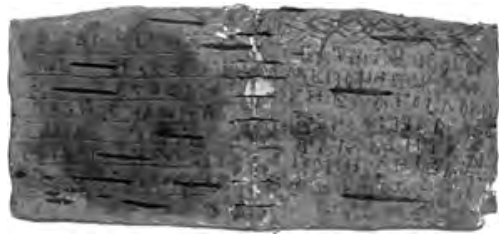

4 achterkant (p. 4)

3 voorkant (p. 1)

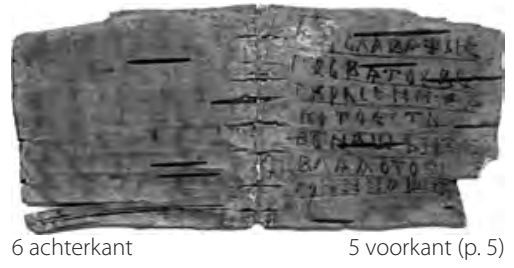

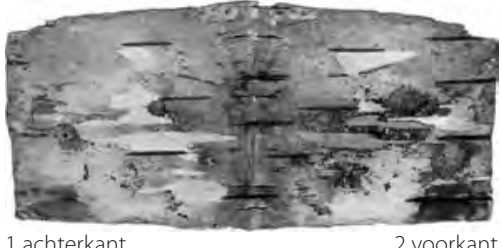

2 voorkant

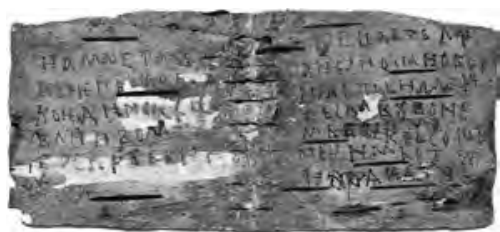

3 achterkant (p. 2)

4 voorkant (p. 3)

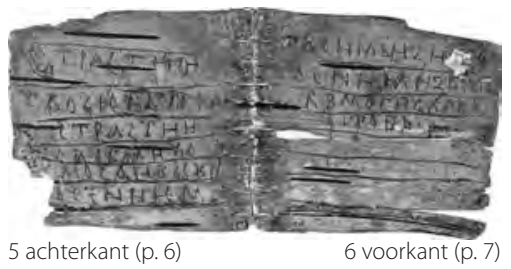

Novgorod nr. 419, ca. 1280-1300

Dit is het enige berkenbastboekje dat tot nu toe is opgegraven. Het bestaat uit drie bladen, zes kantjes, twaalf pagina's. Daarvan zijn er zeven beschreven, beginnend met pagina 1 op de eerste voorkant van het tweede blad. In het midden van de bladen zijn duidelijk de gaatjes te zien voor de stiksels die het boekje bij elkaar moesten houden.

De inhoud bestaat uit twee bekende liturgische avondgebeden. Vermoed wordt dat de teksten, waarin nogal wat fouten zitten, door een koorzanger zijn opgeschreven voor eigen gebruik. 
'Bevrijd de dienaar Gods Michej van de koorts'

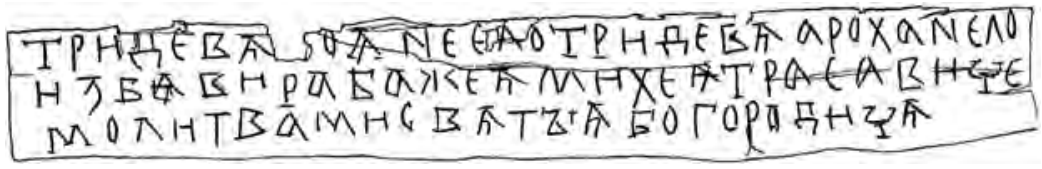

Novgorod nr. 715, ca. 1220-1240

Drie keer negen engelen, drie keer negen aartsengelen. Bevrijd de dienaar Gods Michej van de koorts door gebeden van de Heilige Moeder Gods.

Dit stukje berkenbast werd als bezweringsformule tegen koorts gebruikt, waarschijnlijk in de vorm van een amulet of talisman.

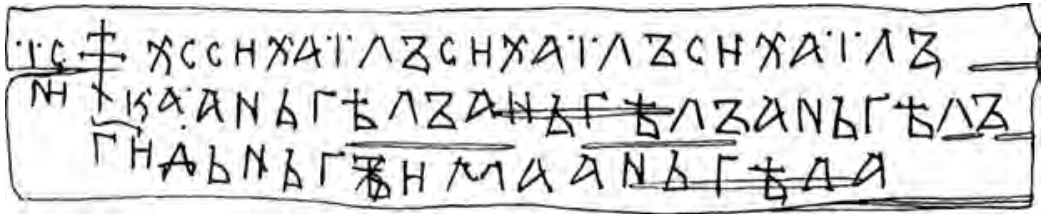

Novgorod nr. 734, ca. 1140-1160

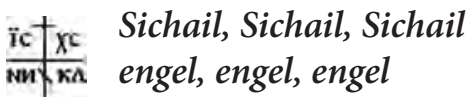

des Heren 3 keer de naam van de engel

Ook deze tekst is duidelijk een bezwering, waarbij de lezing van de derde regel overigens niet zeker is. De aartsengel Sichail (Sachiël) wordt in andere bronnen vaak aangehaald als uitdrijver van koorts. Links van de spreuk staat aan weerszijden van een achthoekig kruis de bekende Griekse formule 'Jezus Christus overwint'. 
'wueerhcseg teh egewnav'

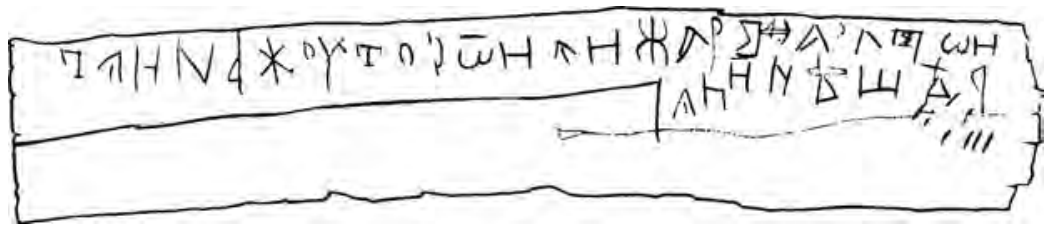

Novgorod nr. 674, ca. 1180-1200

... vanwege het geschreeuw van de vijand, vanwege de kwelling van de goddeloze ...

Op zich is deze tekst niet erg bijzonder: het gaat om een fragment van vers 4 van Psalm 55. Opmerkelijk is echter dat de tekst in spiegelbeeld is geschreven, alsof er in vertaling en zonder woordscheidingen zou staan:

gnillewkedegewnavdnajivednavwueerhcsegtehegewnav ezoleddogednav

Een ongebruikelijke schrijfrichting zijn we al tegengekomen in $\mathrm{nr}$. 46 (p. 100), waar we duidelijk te maken hebben met een woordspelletje. In het geval van de gespiegelde psalmtekst moeten we eerder denken aan een bezwering tegen onheil.

De erg dunne bast van nr. 674 is in een strak opgerolde vorm gevonden, wat aanleiding geeft tot de gedachte dat hij ergens in heeft gezeten. Uit de Russische volkscultuur is bekend dat psalmteksten in talismannen werden meegedragen. Ook hebben we andere voorbeelden in het Oudrussisch waaruit blijkt dat spiegelschrift werd gebruikt om een religieuze tekst een extra magische lading te geven. 
'Instructie van de priestersvrouw aan de priester'

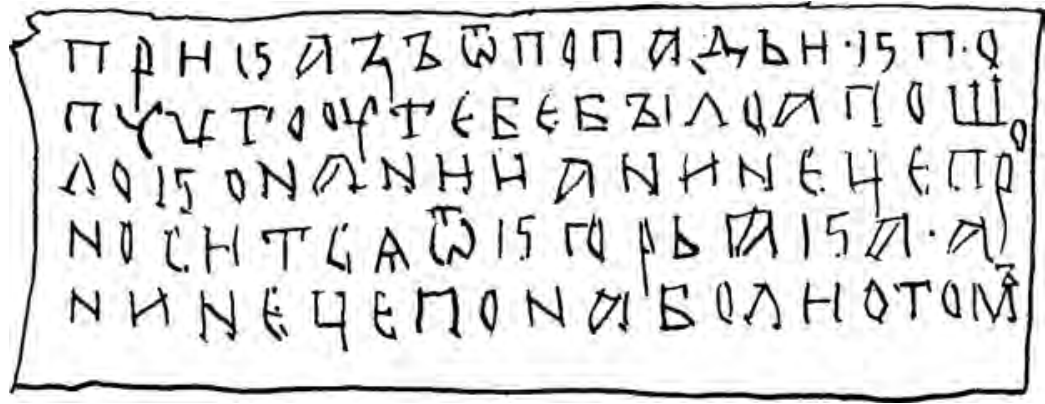

Novgorod nr. 538, ca. 1380-1400

Instructie van de priestersvrouw aan de priester. Wat jou is overkomen, is bij Onanija terechtgekomen, en wordt nu door Kjoerjak rondgebazuind. Dus, draag er zorg voor.

Er is iets gebeurd met de priester dat nu wordt rondverteld. Zijn vrouw wil hem daarvan op de hoogte brengen en wil dat hij actie onderneemt. De aanhef met het woord 'instructie' spreekt boekdelen.

Het lijkt er sterk op dat het voorval compromitterend is voor de priester; er wordt immers over geroddeld. Wellicht om die reden noemt zijn vrouw niet de aard van de kwestie en wil ze haar boodschap zo veel mogelijk geheim houden voor pottenkijkers, zoals bijvoorbeeld voor de koerier van de brief.

De vaagheid van de brief kan verder ook te maken hebben met het feit dat de vrouw haar 'instructie' door iemand anders heeft laten opschrijven. Er is echter geen dwingende reden om dit te veronderstellen. 
'Want de kerk is zonder dienst'

Novgorod nr. 963, ca. 1416-1421

Aan de heer aartsbisschop van Novgorod, Excellentie Semen: jouw boeren - het district van de Heilige Moeder Gods, de nederzetting Osjevo, die van Rzjev - buigen allen, van jong tot oud, nederig voor jou, heer. We hebben gestuurd, heer, de diaken Oleksadr, want (zijn) vader en zijn grootvader hebben gezongen in de Heilige Moeder Gods in Osjevo. En moge jij, heer, die diaken wijden tot priester van de Heilige Moeder Gods. En uit de nederzetting hebben we met hem Troefan gestuurd, want de kerk is zonder dienst. En een andere zaak, heer Excellentie: het altaar in de kerk... Hoe, heer, beschik je hierover?... Wijd het altaar in, heer.

De tekst bestaat uit drie fragmenten die samen bijna een volledig document vormen. Het kan nauwkeurig gedateerd worden omdat we uit andere bronnen weten dat de aartsbisschop Semen (Simeon) tussen 1416 en 1421 in functie was. Ook weten we precies waar het verzoekschrift van de boeren vandaan komt: uit waar nu het dorp Asjevo ligt, ongeveer tweehonderd kilometer ten zuidwesten van Novgorod, in de buurt van Pskov.

Het is duidelijk wat de boeren willen: hun kerk heeft een priester nodig en de diaken Oleksadr heeft daarvoor de juiste papieren. Ze hebben hem samen met plaatsgenoot Troefan naar Novgorod gestuurd om hem te laten wijden door Semen. Op het eind van de brief stippen ze nog een andere kwestie aan: er is iets aan de hand met het altaar waarover Semen moet beslissen en dat hij ook moet inwijden. 


\section{Ooggetuigen van de geschiedenis}

'Ze hebben vrede gesloten aan de oude grens'

Novgorod nr. 286, uit 1351 of vlak daarna

Van Grigori aan Dmitr. We maken het goed. Ga je gang, wees niet bevreesd; ze hebben vrede gesloten aan de oude grens van vorst Joeri.

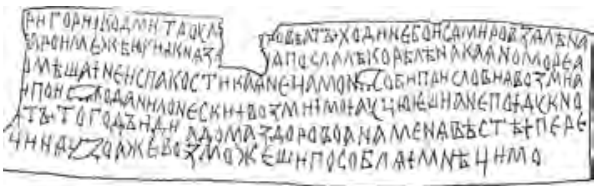

FHPOAHISQ

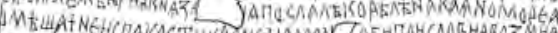

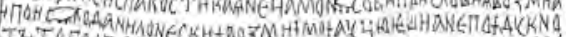
ats Mith

En mij hebben ze naar Karelië gestuurd, naar de Kajan Zee. Stel je voor: je mag de Kajaners niet lastigvallen, hen geen schade toebrengen, en je mag jezelf geen slechte naam bezorgen! Wanneer je de tribuut van vorig jaar hebt opgehaald, neem dan ook de mijne. En als je hoort dat ik niet naar Noja ga, ga jij dan. En thuis is alles goed. Stuur me bericht als er nieuws is. Als je kunt, steun me.

In een aantal gevallen kunnen persoonlijke brieven op berkenbast in verband gebracht worden met historische gebeurtenissen die verder bekend zijn uit kronieken of verdragen. In zijn brief verwijst Grigori met de vrede 'aan de oude grens van vorst Joeri' naar de vernieuwing in 1351 van het verdrag van Nöteborg/Oresjek dat in 1323 tussen Zweden en Novgorod werd gesloten. De grens die werd overeengekomen liep dwars door het huidige Finland, van de zuidelijke Karelische landengte tussen de Finse Golf en het Ladogameer tot het noorden van de Botnische Golf in de Oostzee.

Uit meerdere teksten weten we dat Grigori en Dmitr (die wellicht broers waren) actief waren als belastinginners in het noordelijke achterland van Novgorod (vergelijk nr. 403, p. 125). Grigori spoort Dmitr aan om zijn werk te gaan doen in het weer veilige Zuid-Karelië. Zelf wordt hij naar het noorden gestuurd, naar de 'Kajan Zee', de punt van de Botnische Golf. Hij is daar niet blij mee ('stel je voor!'), had er ook niet op gerekend, en vraagt nu Dmitr om enkele taken van hem over te nemen. 
'Ons is schade toegebracht van Zweedse zijde'

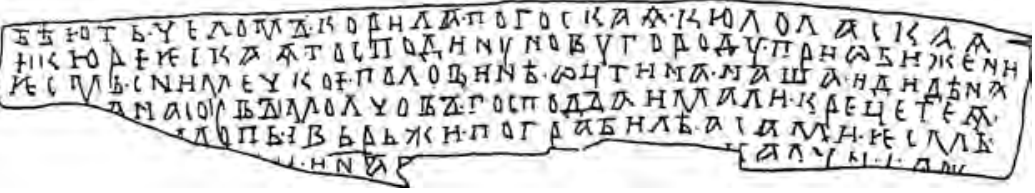

Novgorod nr. 248, ca. 1380-1400

De Kareliërs van de nederzettingen Kjoelolaksja en Kirjazj doen nederig een verzoek aan Heer Novgorod. Ons is schade toegebracht van Duitse (d.w.z. Zweedse) zijde. Wat we hebben van onze vaders en grootvaders is weggenomen door de Vymoliërs. En ze hebben de vallen voor de giervalken ingenomen ... het land van de Lappen en fuiken geplunderd. En wijzelf ...

De Karelische plaatsen die in de niet volledig bewaarde brief vermeld worden bevinden zich aan de westkant van het Ladogameer, in het grensgebied met de Zweedse bevolking, voor wie hier (en gewoonlijk ook elders) de brede benaming 'Duits' gebruikt wordt.

De vijandige gebeurtenissen die in nr. 248 genoemd worden, lijken overeen te komen met wat in de kronieken onder het jaar 1396 beschreven wordt, hoewel het de vraag is of het om precies hetzelfde conflict gaat en of de Zweden er inderdaad bij betrokken waren. De Zweden worden in de brief immers niet direct als agressor genoemd; wel de Vymoliërs, een van de bekendste Karelische stammen, die zich wijdverspreid hadden. 
'Het leger heeft toegeslagen bij Koporja'

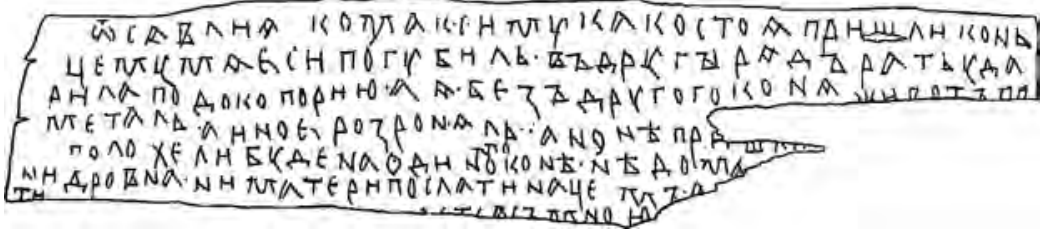

Novgorod nr. 272, ca. 1360-1380

Van Savli aan Maksim. Stuur onmiddellijk een paard. Waarom heb je me geruïneerd? Voor de tweede keer heeft het leger toegeslagen bij Koporja, en ik, zonder een ander paard, heb mijn bezittingen achtergelaten en andere verloren. Stuur me dus nu... Als het onrustig wordt, is er op één paard thuis ... noch brandhout, noch moeder om voor te sturen ...

De geadresseerde van deze brief, waarvan het eind fragmentarisch is overgeleverd, is Maksim Ontsiforovitsj, telg uit het geslacht van de Misjinitsji (zie p. 166).

Koporja was een Novgorodse vesting vlak bij de Finse Golf, waar in de jaren zeventig van de veertiende eeuw meerdere oorlogshandelingen hebben plaatsgevonden met de Zweden.

Nr. 272 heeft daar hoogstwaarschijnlijk betrekking op, maar het is de vraag of die gebeurtenissen Savli's eerste zorg waren, of hij zijn brief schreef uit hoofde van een of andere militaire functie. Immers, hij beklaagt zich in de brief over zijn eigen omstandigheden, die zonder een tweede paard desastreus zullen aflopen; er kan dan blijkbaar thuis verder niks gedaan worden, geen brandhout worden aangevoerd en zijn moeder kan hij dan ook niet meer zien. Het lijkt er dus eerder op dat Savli met Maksim Ontsiforovitsj in een of andere persoonlijke relatie stond en dat hij hem op dwingende toon vraagt om iets aan zijn miserabele situatie te doen. 


\section{'Litouwen is opgetrokken tegen Karelië'}
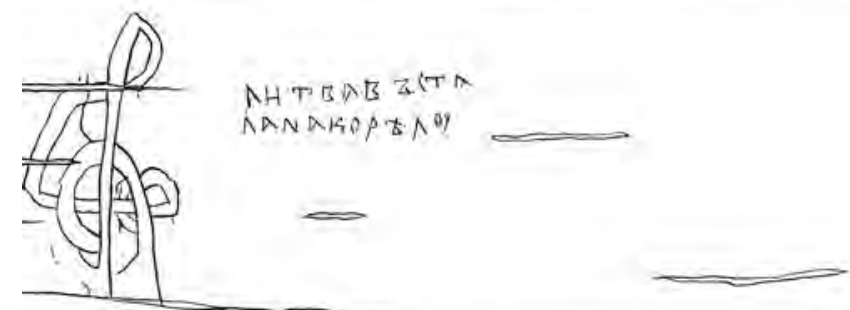

Novgorod nr. 590, ca. 1065-1100

\section{Litouwen is opgetrokken tegen Karelië.}

Op een groot stuk berkenbast van meer dan veertig centimeter breed vinden we een kleine notitie met links daarvan een figuur die lijkt op een muzieksleutel. Omdat het bericht verder geen afzender of ontvanger kent, gaat het wellicht om een of ander teken (een monogram?) ter nadere identificatie voor de correspondenten.

Als we de datering en inhoud van de berkenbast vergelijken met historische gebeurtenissen die bekend zijn uit de kronieken, dan moet het bericht verband houden met de veldtocht in 1069 van vorst Vseslav Brjatsjislavitsj van Polotsk tegen Novgorod. Het vorstendom Polotsk lag ten zuidwesten van Novgorod, in wat nu WitRusland is. Binnen zijn invloedssfeer lag in de elfde eeuw het westelijker gelegen gebied van de Litouwers.

De veldtocht van 1069, waaraan de Litouwers meededen, liep door het Votische land, gelegen aan de Finse Golf en grenzend aan Karelisch gebied. Hier moeten de Litouwers met de Kareliërs slaags zijn geraakt. Het is goed mogelijk dat nr. 590 een rapportage is die vanuit dit oorlogsgebied is verstuurd naar Novgorod. 
'Een vrijgekochte gevangene is uit Polotsk gekomen'

Novgorod nr. 636, ca. 1260-1280

Een vrijgekochte gevangene is uit Polotsk gekomen en bericht over een groot leger. Lever dus tarwe voor het garnizoen.

Net als in de vorige tekst, nr. 590, gaat het hier om een bericht van het 'front' en ook hier worden afzender en geadresseerde niet genoemd, waarschijnlijk vanwege de vertrouwelijkheid van de zaak. Het toeval wil echter dat er een andere brief is overgeleverd die in hetzelfde handschrift is. Het gaat om het fragment Novgorod nr. 704: Van de vestingbewoners aan de groot-stadhouder. De inwoners van Jasenskoje zijn gevlucht ...

De plaats die de briefschrijver in nr. 704 noemt ligt aan de zuidwestelijke grens van het Novgorodse land. Deze geografische oriëntatie komt overeen met de vermelding van Polotsk in nr. 636 (zie ook het commentaar bij de vorige tekst, nr. 590).

De vijandigheden tussen Polotsk en Novgorod moeten na 1263 hebben plaatsgevonden. In dat jaar werd de met Novgorod bevriende vorst van Polotsk, de Litouwer Tautvilas, vermoord. De nieuwe Litouwse machthebbers daarentegen stonden vijandig tegenover Novgorod.

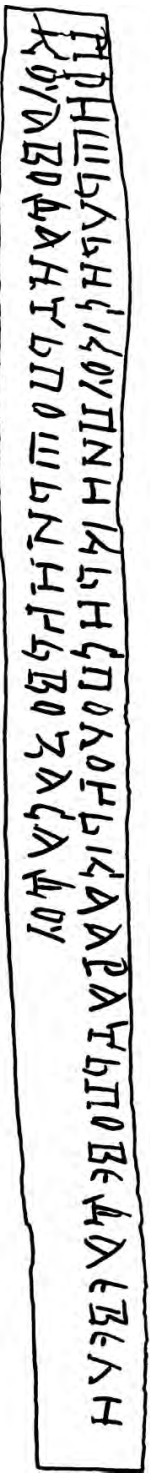


'Laat Sava geen enkele poolvos van hen innen'

Novgorod nr. 724, ca. 1160-1180

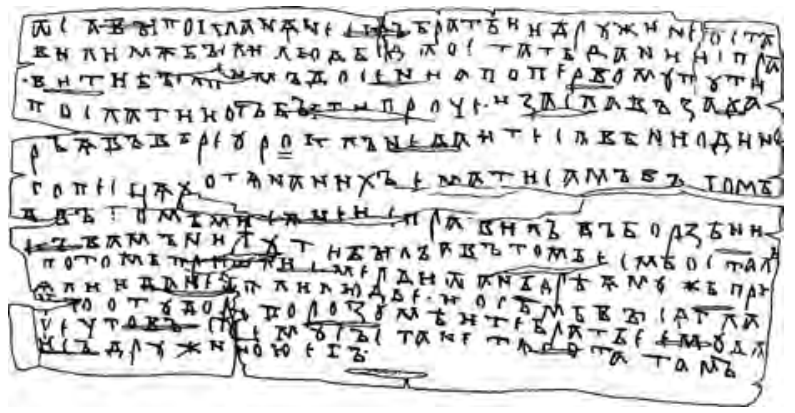

(Buitenkant) Van Sava een groet aan de broers en gevolg. De mensen hebben me verlaten, hoewel ze de rest van de tribuut hadden moeten afhandelen voor de herfst en moeten versturen zodra de wegen weer begaanbaar waren, en verder trekken. Maar Zacharja heeft een man gestuurd en via hem onder ede bepaald: "Laat Sava geen enkele poolvos van hen innen. Ik ben daar zelf voor verantwoordelijk." En daarom heeft hij niet meteen daarop met mij afgerekend en was hij noch bij jullie, noch hier. Daarom ben ik gebleven. Daarna zijn de boeren gekomen, hebben de man van Andrej erkend en hebben zijn mensen de tribuut opgehaald. En acht mensen onder Toedor hebben zich aan zijn gezag onttrokken. Heb begrip voor hem, broers, mochten hij en zijn gevolg daarom in moeilijkheden komen.

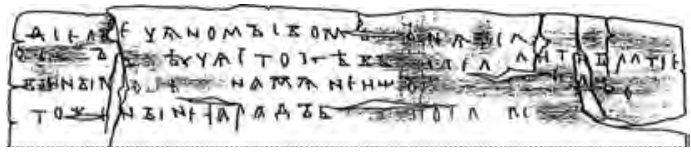

(Binnenkant) En de vorst heeft zelf aan zijn dorpelingen stukken land gegeven langs de Volok en de Msta. Broers, als de mensen mij niet als schuldige vervolgen en er een onderzoek komt, dan stuur $i k$ meteen met plezier een brief. 
In nr. 724 stelt de briefschrijver Sava niet zo maar een conflict aan de orde over het innen van belasting. Op grond van informatie uit de kronieken kunnen we de brief verbinden met een historische episode waarin Novgorod overhoop lag met het naburige vorstendom Vladimir-Soezdal over het recht op belastingheffing in de noordoostelijke periferie van het Novgorodse land. Op die noordelijke regio duiden de twee toponiemen Volok en Msta op de binnenkant van de berkenbast, als ook de vermelding van poolvossen op de buitenkant.

De in de brief genoemde persoon Zacharja kan geïdentificeerd worden als de posadnik (stadhouder) van Novgorod in de periode 1161 tot aan zijn dood in 1167. De archeologische datering 11601180 van nr. 724 komt met deze historische informatie uitstekend overeen. De toenmalige vorst van Novgorod, naar wie wordt verwezen op de binnenkant, was Svjatoslav Rostislavitsj. We weten ook wie de in de brief vermelde Andrej was: Andrej Joerjevitsj Bogoljoebski, vorst van Soezdal tussen 1157 en 1174, en meerdere keren agressor tegen Novgorod in de noordoostelijke gebieden.

Tegen deze historische achtergrond vertelt Sava zijn eigen onfortuinlijke verhaal. (Over zijn taalgebruik zie p. 40.) Sava is bij het innen van belasting door zijn eigen posadnik Zacharja terzijde geschoven, terwijl zijn eigen vorst toch duidelijk het gebied aan de dorpelingen heeft toegewezen. Dit duidt op een interne machtsstrijd tussen de posadnik en de vorst. In het ontstane vacuüm is Andrej Bogoljoebski gesprongen en de belastingplichtige boeren hebben geaccepteerd dat hij de heffing overnam.

Toedor is blijkbaar iemand van Sava's mannen. Hij heeft samen met nog acht anderen geen gehoor gegeven aan Zacharja's opdracht en dreigt nu in de problemen te komen. Sava komt in de brief voor hem op en is best bereid om eventueel tekst en uitleg te geven, mits hij niet zelf vervolgd wordt. 


\section{Buitenlands op berkenbast}

'Gods pijl'

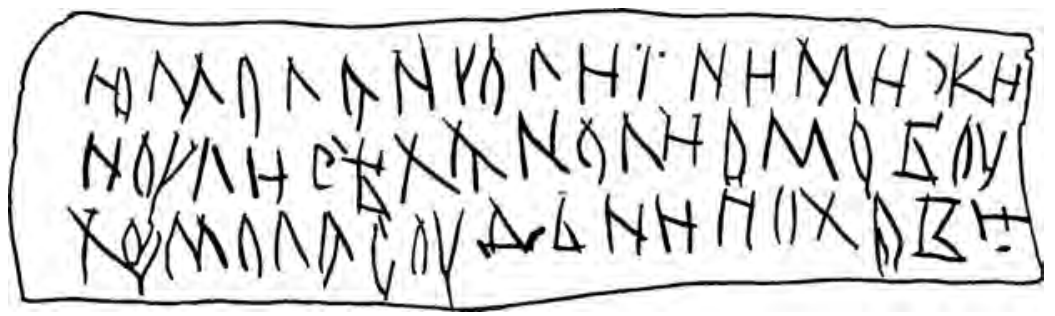

Novgorod nr. 292, ca. 1240-1260

jumolanuliinimiži

nulisě $[x]$ anoliomobu

[xu]molasudonipoxov[i]

Schrijven op berkenbast was een middeleeuws Russische aangelegenheid, voor en door de hogere lagen van de Slavische bevolking. Getuigenissen van niet-Slavische contacten vinden we op berkenbast hoofdzakelijk in de vorm van plaats-, volkeren- en eigennamen, in het bijzonder van Oostzeefinse (Karelische) origine (vergelijk nr. 286, p. 117, en nr. 248, p. 118). Er is slechts een handvol berkenbastteksten die niet in het Slavisch zijn geschreven.

Nr. 292 wordt hier alleen in transcriptie gegeven, want veel van wat er staat is onduidelijk. Er bestaan meerdere lezingen, met name van Finse filologen die deze verreweg oudste tekst geschreven in een soort van Oostzeefins uitvoerig bestudeerd hebben. Of het specifiek om Karelisch zou gaan, zoals wel eens wordt beweerd, is sterk de vraag. Het is ook niet zeker dat we te maken zouden hebben met een bezwering tegen bliksem. In de eerste regel lezen we 'Gods (Jumala's) pijl' en 'naam', in de tweede staat misschien 'schijn' en 'schiet'; de derde regel is het minst eenduidig van alle. 
'beschaamd, beveel, zuur, ...'

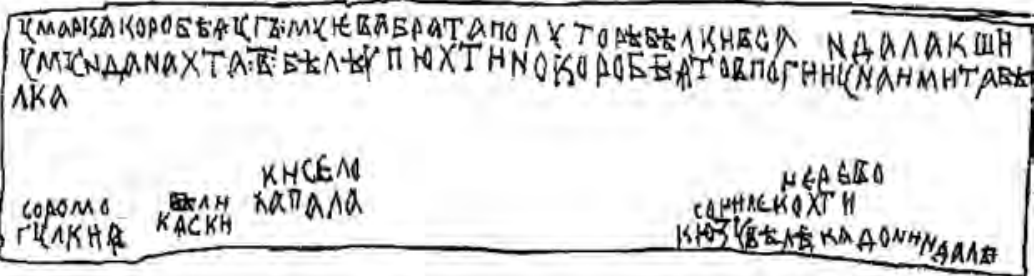

Novgorod nr. 403, ca. 1360-1380

(Boven) Van Mark een kist. In Sandalaksja van Gymoej's broer anderhalve eekhoornvel. Van Moendanacht 2 eekhoornvellen. Van de Pjoechtins een kist. En in Pogija van de knecht een eekhoornvel. (Onder) (1) beschaamd (2) beveel (3) zuur (4) (schuld) opgeëist (5) buikpels (6) lindebast.

Aan het handschrift is te zien dat de tekst afkomstig is van dezelfde Grigori als in nr. 286 (p. 117). In de Russische tekst bovenaan zien we hem weer in de rol van belastinginner in Karelisch gebied: Sandalaksja en Pogija liggen in dezelfde regio als de plaatsen die in nr. 248 (p. 118) worden genoemd.

Onderaan heeft Grigori zes woorden in het Oostzeefins opgeschreven met daarbij de Russische vertaling. Blijkbaar wilde hij ze weten en onthouden. Het zijn niet de eerste woorden die je in een vreemde taal zou leren. Dit suggereert dat Grigori al een elementaire kennis bezat van de taal die gesproken werd in het gebied waar hij werkzaam was. 
'Píl gefal im'?

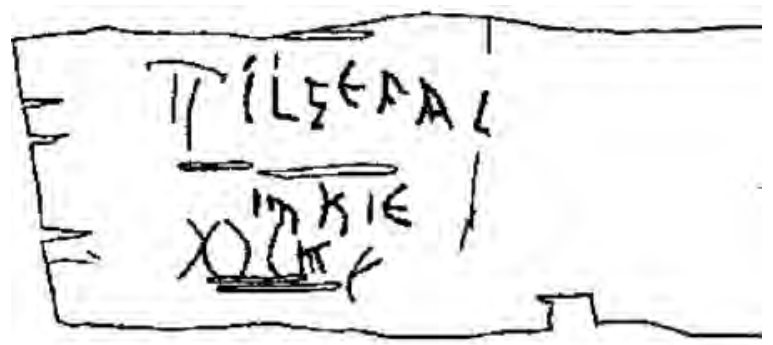

Novgorod nr. 753, ca. 1050-1075

\section{(-)ÍLGEFAL}

IM[K]IE

Aan de linkerkant van een berkenbast die verder leeg is, staan wat letters die hierboven precies zo zijn weergegeven als in de Russische editie uit 2000. Onder de tweede regel staan nog wat strepen die enigszins lijken op letters, maar die ook versieringen zouden kunnen zijn. Wat wel leesbaar is, is in ieder geval in Latijnse letters geschreven, hoewel het allereerste teken onduidelijk is: $P$ of $T$, of misschien een ornament? Of de derde letter in de tweede regel inderdaad een $K$ is, is ook maar de vraag (misschien eerder een $N$ ?).

Het is dus verre van zeker wat er eigenlijk staat. Vooralsnog wordt aangenomen dat de taal Nederduits (Oudsaksisch) is, waarbij het eerste woord píl 'pijl' zou kunnen zijn (maar ook tíl 'doel'), gevolgd door gefal im, waarin we het werkwoord 'vallen' en het meewerkend voorwerp 'hem' herkennen. Wat daarna staat, is nog ongewisser: kie 'geen'? Of moeten we nie 'nooit' lezen? Als we al deze onzekerheden willen verbinden, dan kunnen we speculeren dat er iets stond als 'Pijl, tref hem niet/nooit'. Een bezwering of talisman voor een krijger? Of hebben we het over 'Gods pijl', d.w.z. bliksem, zoals ook gespeculeerd wordt over nr. 292 (p. 124)? 


\section{'Vískarr heeft dit stuk land genomen'}

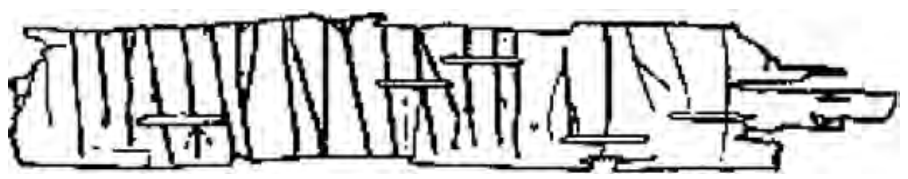

Smolensk nr. 11, ca. 1140-1160

Viskarr heeft dit stuk land genomen.

In Smolensk, zo'n vierhonderd kilometer ten zuiden van Novgorod, zijn tot nu toe zestien berkenbastteksten opgegraven. Daaronder is nr. 11 uniek omdat de tekst de enige is in Scandinavisch runenschrift op berkenbast.

Runeninscripties vinden we verspreid over geheel Europa en getuigen van de aanwezigheid van Vikingen. Dat we ze ook in middeleeuws Rusland tegenkomen is niet verwonderlijk gezien de Scandinavische herkomst van de Russische elite (de Rjoerik-dynastie) en de grotendeels op Russisch grondgebied liggende handelsroute tussen Scandinavië en Byzantium (zie ook p. 23).

Er zijn runeninscripties vanaf de negende eeuw overgeleverd op voorwerpen van steen, hout, bot en edelmetaal, die gevonden zijn over een groot gebied: in het noorden, in en rondom Novgorod; zuidelijker, in Smolensk en de Dnjepr-regio; en oostelijker, in Soezdal.

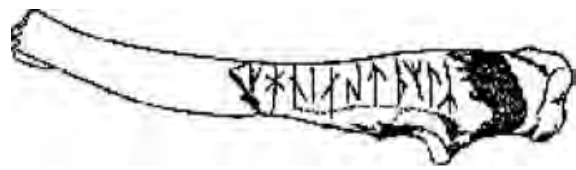

Novgorod, eerste helft elfde eeuw: varkensbot met runenalfabet (futhark) 


\section{'Venite, exultimus Domino'}

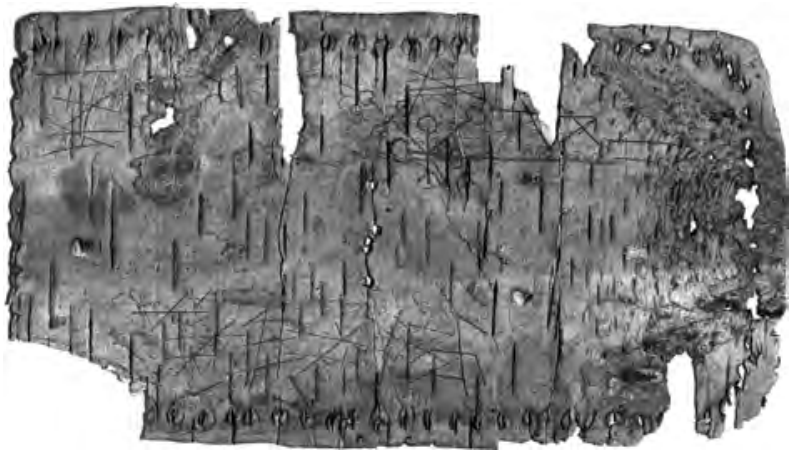

Novgorod nr. 488, ca. $1380-1400$

Zoals te zien is op de foto, heeft het grote stuk berkenbast $(28,5 \mathrm{x}$ $15,5 \mathrm{~cm}$.) gaatjes aan de zijkanten en was het oorspronkelijk onderdeel van een mandje (vergelijk nr. 199, p. 102).

Nr. 488 bevat zes regels in het Latijn. De eerste drie geven Psalm

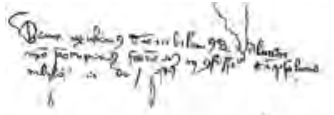

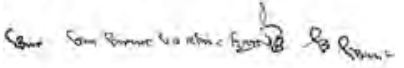

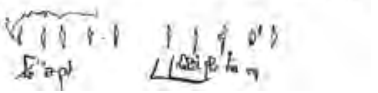

95:1-2 ('Komt, laat ons jubelen over de Here ...) weer. De tekst speelt een speciale rol in de Latijnse liturgie, waar ook de overige drie regels mee verbonden kunnen worden. We lijken te maken te hebben met een liturgische reminder, hetzij voor een priester of een leek.

Dat we deze Latijnse tekst in Novgorod aantreffen, is niet zo verwonderlijk wanneer we bedenken dat hij gevonden is op de Handelszijde van de stad, op de plek waar zich de Gotenhof bevond (de handelspost voor kooplui uit Visby op Gotland; zie de kaart op p. 17) en waar ook keramiek uit de Rijnstreek en houten gebruiksvoorwerpen met daarop Hanzische koopmanstekens gevonden zijn. De chaotisch lijkende krassen die we hier en daar op nr. 488 kunnen zien, doen sterk denken aan dergelijke eigendomstekens. 
'Aan Mercurius de krijger'

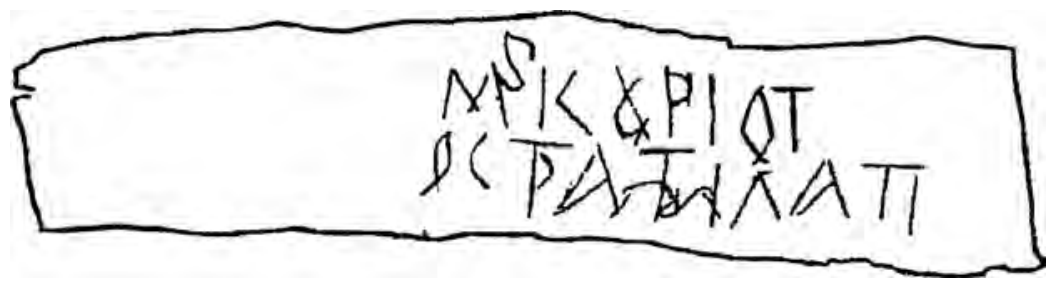

Novgorod nr. 552, ca. 1180-1200

\section{Aan Mercurius de krijger.}

Dit stukje berkenbast met een Griekse tekst erop - M(E)PKOYPIO TO $\Sigma$ TPATI $\Lambda$ ATI - is opgegraven op dezelfde plek en dezelfde diepte waar ook de teksten van de iconenschilder Olisej Gretsjin zijn gevonden (zie nr. 549, p. 111). Er zijn natuurlijk meerdere verklaringen mogelijk waarom iemand 'Aan Mercurius de krijger' optekent, maar we zouden te maken kunnen hebben met een aantekening die verband houdt met een icoon gewijd aan de Heilige Mercurius: misschien betreft het een bestelling die uitgevoerd moest worden en is nr. 552 vergelijkbaar met andere (Russische) lijstjes van heiligen die op dezelfde plaats zijn aangetroffen.

De Heilige Mercurius (224-250) werd met name vereerd in Smolensk, waarvandaan in de twaalfde en dertiende eeuw meerdere vorsten naar Novgorod werden gehaald. 



\section{Teksten II: Communicatie}

Dit deel concentreert zich op enkele bijzondere aspecten van communicatie via berkenbastbrieven en sluit af met een presentatie van teksten die met elkaar verbonden kunnen worden in bredere Sociale netwerken (p. 160 e.v.).

In eerste instantie gaan we kijken naar een aantal brieven waaruit blijkt dat communicatie op berkenbast een Oraliteitsfactor (p. 133 e.v.) kon hebben: brieven konden worden 'gesproken' (gedicteerd) en 'gehoord' (voorgelezen).

De belangrijke Rol van de koerier (p. 138 e.v.) wordt behandeld aan de hand van een tweede reeks brieven. De koerier kon in brieven expliciet of impliciet genoemd worden en kon ook belanghebbende zijn in de communicatie tussen afzender en ontvanger. Hij kon verder extra mondelinge informatie overbrengen als toelichting of aanvulling op de geschreven boodschap.

In derde instantie komen ongelijksoortige of Heterogene brieven (p. 148 e.v.) aan de orde: brieven waarin verschillende personen direct en individueel worden aangesproken op een manier die je niet zou verwachten op basis van de aanhef en de daarin genoemde geadresseerde(n). Dit soort brieven valt eigenlijk in meerdere delen uiteen met elk een verschillend referentieperspectief. Eerst wordt bijvoorbeeld persoon $x$ aangesproken en vervolgens persoon $y$. Het bijzondere daarbij is dat de overgangen tussen die verschillende perspectieven niet expliciet in de tekst worden gemarkeerd.

Dat er een discrepantie kan bestaan tussen de geadresseerde(n) in de aanhef en degene(n) die in de brief wordt of worden aangesproken, hebben we overigens al een paar keer gezien: in nr. 424 (p. 47) richt Gjoergi zich niet alleen tot vader en moeder, maar tot de hele familie; nr. 370 (p. 72) en Staraja Roessa nr. 39 (p. 46) zijn beide aan twee personen geadresseerd, terwijl de briefschrijver zich slechts tot één persoon richt; anderzijds is Pskov nr. 6 (p. 45) aan één persoon geadresseerd, maar wordt er in de brief gesproken 
van 'jullie'. Dit soort discrepanties zijn voor ons vanuit een modern communicatieperspectief niet vreemd. In heterogene berkenbastbrieven gaat men echter nog een stap verder, op een manier die alleen te begrijpen valt wanneer we de oraliteitsfactor en vaak ook de speciale rol van de koerier in ogenschouw nemen.

In thematisch opzicht vallen bijna alle teksten in dit deel in de categorieën Handel en geld (vergelijk p. 42 e.v.) en Recht en bestuur (p. 54 e.v.). Uitzonderingen zijn de persoonlijke uitnodiging van Gavrila Postnja aan zijn zwager en zus (nr. 497, p. 147) en de brief van een collectief boeren aan hun landheer (nr. 406, p. 158). In sommige gevallen is het thema van de mededeling onbekend ( $\mathrm{nr}$. 79 , p. 142 ; nr. 397 , p. 145 ; nr. 443 , p. 145 ; nr. 656 , p. 146$).$ 


\section{De oraliteitsfactor}

'Van Zjila aan Tsjoedin' én 'Van Zjila aan Sava'

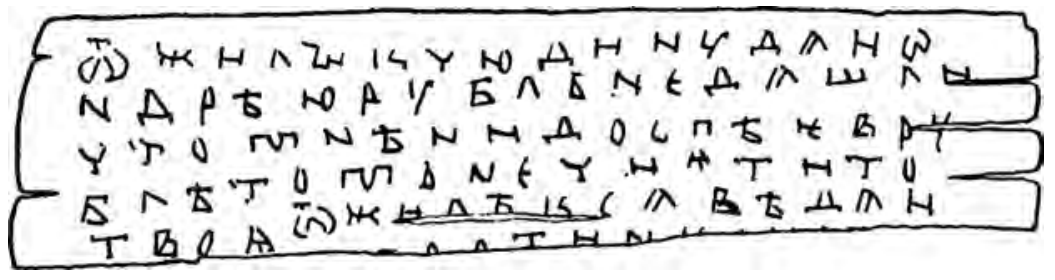

Novgorod nr. 589, ca. 1340-1360

Van Zjila aan Tsjoedin. Geef Ondrei een roebel. Als je hem niet geeft, dan is elke blaam die Ondrei op mij laadt vanwege die roebel voor jouw rekening. Van Zjila aan Sava. Geef ... een halve roebel ...

Het eind van de berkenbasttekst is niet bewaard gebleven, maar duidelijk is dat we te maken hebben met twee verschillende brieven van dezelfde afzender. Zjila begint met een instructie en een waarschuwing aan Tsjoedin. Direct daarop volgend, in het midden van de vijfde regel (vijfde letter), begint hij zijn tweede brief, nu gericht aan Sava.

De voor de hand liggende gedachte is dat het de bedoeling was dat de brieven van Zjila werden voorgelezen door de koerier. Hoe anders kunnen we twee brieven op één berkenbast verklaren, brieven die grafisch naadloos op elkaar aansluiten en niet of nauwelijks van elkaar te scheiden zijn. 
'Van Radko aan vader' én 'Van Vjatsjesjka aan Lazor'

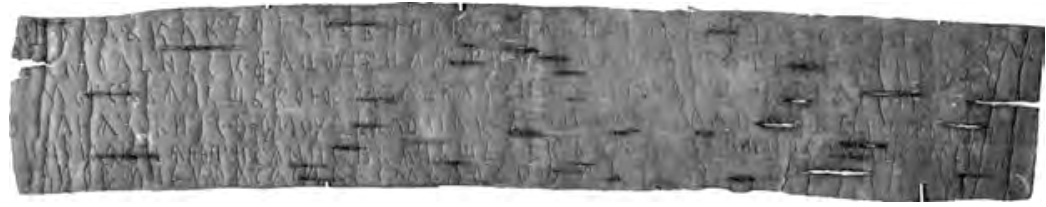

Novgorod nr. 952, ca. 1140-1160

Groet van Radko aan vader. Ik heb de spullen naar Smolensk gestuurd. Maar Poetila is vermoord en ze willen mij en Vjatsjesjka in de plaats van Foma, en zeggen: "Betaal 400 grivna's of roep Foma hierheen, anders stoppen we jullie in het gevang." En groet van Vjatsjesjka aan Lazor. Ik heb het pakpaard gestuurd, en zelf ben ik gereed.

In de brief komt een juridische procedure aan de orde (roebezj geheten) die we al eerder zijn tegengekomen in bijvoorbeeld nr. 246 (p. 58). Hier wordt de Novgoroder Foma verdacht van de moord op Poetila in een vreemde stad, maar kan niet worden opgepakt. In plaats van hem dreigen nu andere Novgoroders, met name Radko en Vjatsjesjka, die zich in dezelfde stad ophouden, op te moeten draaien voor de vermeende moord.

Deze berkenbast bestaat, net als de vorige, nr. 589, uit twee brieven en ook hier gaat de eerste direct over in de tweede. De gehele tekst is zonder twijfel in een en hetzelfde handschrift, wat betekent dat een van de berichten (of misschien zelfs beide) gedicteerd moet zijn. Of de brief ook aan twee verschillende personen is gestuurd en in dat geval waarschijnlijk aan hen is voorgelezen - is nog maar de vraag; 'vader' en Lazor kunnen immers dezelfde persoon zijn. 
'Bedenk eens zelf'

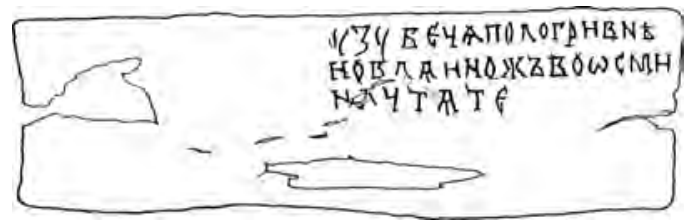

Binnenkant: Van Zoebets ...

Novgorod nr. 750, ca. 1300-1320

(Buitenkant) Groet van Stepan aan Potka. Bedenk eens zelf: je stuurt me de wapenrusting zelf niet, noch de vergoeding daarvoor, noch de betaling voor de boeien; geen koena's, geen zilver, geen twee vleesklompen.

(Binnenkant) Van Zoebets een halve nieuwe grivna en een mes voor achttien

De brief is opmerkelijk vanwege de laconieke manier waarop de afzender een zekere Potka - een wijdverspreide bijnaam die 'de Vogel' betekende - tot de orde roept. Stepan eist niets, dreigt niet expliciet en maakt geen openlijke verwijten; hij werkt op Potka’s geweten door simpelweg de feiten op te sommen.

Zo te zien is Stepan een wapensmid of iemand die in wapens handelt. Hij wil betaald worden in koena's, zilver of 'twee vleesklompen', een eenheid in natura die wel vaker voorkwam in de Russische Middeleeuwen.

Op de binnenkant van de berkenbast staat in hetzelfde handschrift een tweede tekst die losstaat van de brief en dus blijkbaar niet gericht is aan Potka. De tekst lijkt op een reminder: bij Zoebets moet nog het een en ander opgehaald worden. Het ligt voor de hand om te veronderstellen dat de koerier van de brief dat moest doen. Dit zou betekenen dat het niet de bedoeling was dat de brief aan Potka werd afgegeven, maar aan hem werd voorgelezen (en misschien ook getoond) door de koerier, die de berkenbast immers nog nodig had om de opdracht bij Zoebets uit te voeren. 
'Ik hoor van je wat je zegt'

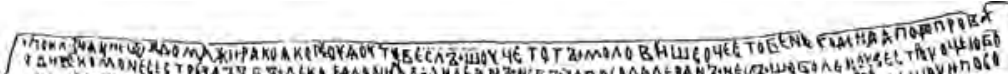

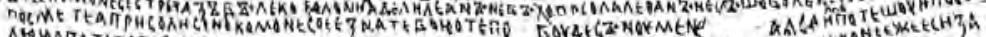

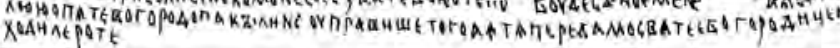

Novgorod nr. 705, ca. 1200-1220

+ Groet van Domazjir aan Jakov. Ik hoor van je wat je zegt. Als ze jou niet bevalt, stuur dan (mijn) zuster naar me terug. Vorig jaar heb ik (haar een of ander eigendom) toegewezen en nu zou ik (haar deel) willen sturen. En nu hoor ik dat mijn zuster ziek is. Als God haar neemt, stuur me dan (haar) zoon samen met de znatjba; laat hij bij me zijn als mijn zoon en ik zal door hem getroost worden. En daarna stuur ik haar (de znatjba) terug naar de stad. Als je dit niet uitvoert, zal ik je overgeven aan de Moeder Gods, voor wie je de eed hebt gezworen.

De brief gaat over de zus van Domazjir en het is aannemelijk dat de geadresseerde, Jakov, haar man is. In de tekst komt het woord znatj$b a$ voor, waarvan we niet goed weten wat het betekent (een soort van eigendomsbewijs, een testament?).

Wat hier van belang is dat we kunnen veronderstellen dat ' $\mathrm{Ik}$ hoor van je wat je zegt' letterlijk moet worden opgevat, d.w.z. 'Jouw bericht is aan mij voorgelezen'. Voor de praktijk dat berichten op berkenbast werden voorgelezen hebben we immers meer aanwijzingen. Bovendien geeft in dit specifieke geval de subtiliteit van de zin zoals hij in het Oudnovgorods is gesteld, extra aanleiding voor deze veronderstelling.

Overigens kunnen we nu nog steeds 'horen' gebruiken wanneer het om informatie uit geschreven teksten gaat, bijvoorbeeld in zinnen als 'ik heb al lang niets van je gehoord', d.w.z. 'ik heb al lang geen brief van je gekregen'. 
'Mestjata groet jullie'

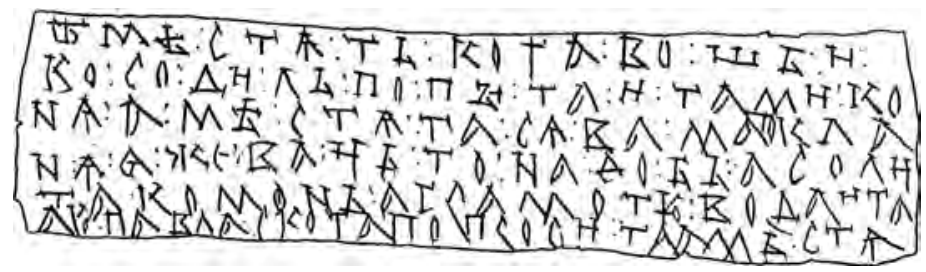

Novgorod nr. 422, ca. 1140-1160

Van Mestjata aan Gavsja en aan Sdila. Zoek me een paard. En Mestjata groet jullie (beiden). Als jullie iets nodig hebben, stuur dan iemand naar me en geef hem een brief mee. En vraag Pavel om geld. En Mestja(ta)

Het is duidelijk dat Mestjata van Gavsja en Sdila drie dingen wil: ze moeten op zoek naar een paard, ze moeten met hem in contact blijven en ze moeten geld aan Pavel vragen. Hoe die zaken zich precies tot elkaar verhouden weten we niet.

Wat doet echter de mededeling 'En Mestjata groet jullie' middenin de brief? De brief komt van Mestjata, dus waarom staat deze zin niet in de eerste persoon? Blijkbaar is Mestjata niet de briefschrijver en komt de groet niet rechtstreeks van hem.

Het is mogelijk dat de schrijver zich per ongeluk niet heeft verplaatst in Mestjata voor wie hij de brief schrijft, en dat hij daarom een derde persoon gebruikt. Het is echter aannemelijker dat de brief de werkelijke communicatieve gang van zaken weergeeft: de brief werd voorgelezen, waarbij het informatieve gedeelte (de drie verzoeken) vanuit het perspectief van de afzender wordt overgebracht, terwijl de formele groet rechtstreeks uit de mond van de boodschapper wordt opgetekend.

Dat de boodschapper tegelijkertijd de schrijver van de brief is, is in dit scenario goed voorstelbaar: hij is immers de persoon die de groet daadwerkelijk overbrengt. 


\section{De rol van de koerier}

'Geef aan deze dienaar'

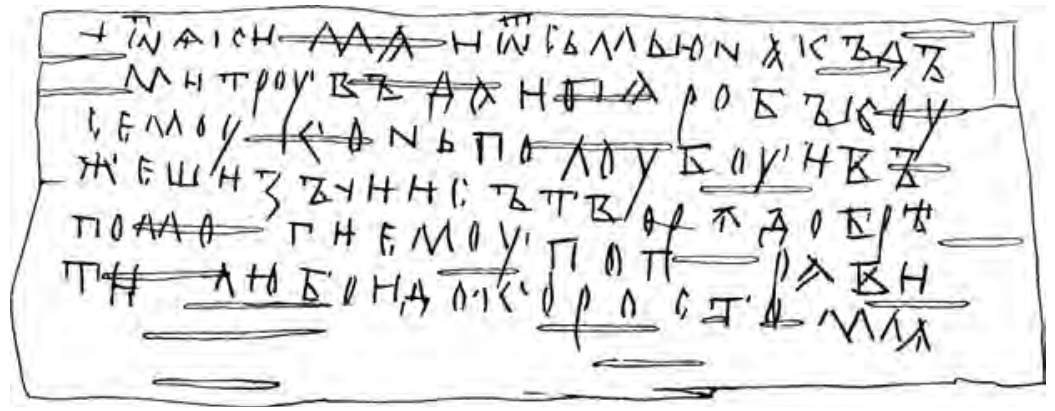

Novgorod nr. 735, ca. 1140-1160

+ Van Jakim en van Semjoen aan Dmitr. Geef aan deze dienaar het halfwilde (?) grijze paard en, wees zo goed, help hem (de vracht) te bezorgen, ook al is het tot Korostoml.

Wat voor soort paard er precies gegeven moet worden, en of de twee afzenders doelen op een specifiek paard, is niet helemaal duidelijk. Ook het toponiem Korostoml kan niet achterhaald worden.

Waar het in deze brief echter om draait, is de aanduiding 'aan deze dienaar', en meer in het bijzonder het aanwijzend voornaamwoord 'deze'. Het ligt voor de hand om te veronderstellen dat Jakim en Semjoen verwijzen naar degene die de brief aan Dmitr overhandigt. Met 'deze dienaar' wordt dus de koerier bedoeld, die met een mandaatbrief voor een paard en verdere hulp bij Dmitr komt.

Op dezelfde manier kunnen ook andere berkenbastbrieven worden uitgelegd, zoals bijvoorbeeld Novgorod nr. 739 (ca. 11201140): Van Glebko aan de inwoners van Volok. Geef aan deze diaken vijf en een kerk-grivna... 


\section{'Geef aan deze man wat hij heeft gezegd'}

Novgorod nr. 879, ca. 1120-1140

Van Zjirjata een groet aan Radjata. Geef aan deze (man) wat hij heeft gezegd - dat graan.

Deze korte brief valt in dezelfde categorie als de twee vorige, $\mathrm{nr} .735$ en nr. 739: het aanwijzend voornaamwoord 'deze' (zonder verdere specificatie van de persoon) verwijst naar de koerier die met een mandaatbrief naar Radjata is gestuurd.

Wat nr. 879 bijzonder maakt is dat Zjirjata expliciet een gesproken mededeling autoriseert: '... wat hij heeft gezegd'. Hij gebruikt daarbij de verleden tijd van zeggen omdat hij zich oriënteert op het moment dat de brief wordt gelezen door Radjata, nadat de koerier de instructie al mondeling heeft overgebracht.

Het laatste stukje van de brief - 'dat graan' - wijst erop dat Zjirjata de kern van de instructie alsnog voor de zekerheid op schrift wilde hebben, waarbij dat blijkbaar betrekking heeft op graan dat al een keer ter sprake is geweest tussen hem en Radjata. Verdere details van de instructie laat Zjirjata vervolgens aan de koerier over.

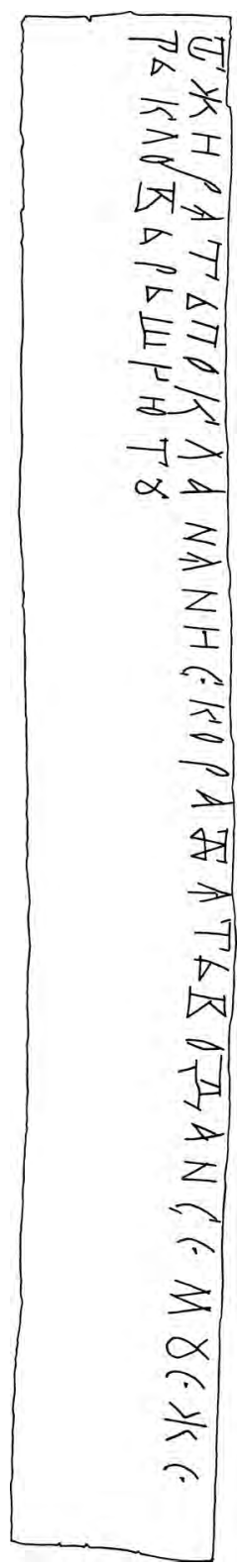


'En dit is Goimer, die uit Tsjernigov, met zijn vrouw'

Novgorod nr. 1004, tweede helft twaalfde eeuw

(Voorkant) + Van Loeka aan vader. De knecht die mij heeft vervoerd, heeft niet het geld gegeven voor de huiden. Ik heb hem voor 6 nogata's pannen verkocht; in totaal een volle 2 (grivna's). En hij is op de boot met de waar. Neem dus van hem twee grivna's. En als hij zich eruit draait, stel hem dan in kennis en leg hem drie (grivna's) $o p$.

(Achterkant; $180^{\circ}$ gedraaid) + Van Loe

(Achterkant; linkerzijde) En dit is Goimer, die uit Tsjernigov, met zijn vrouw; haar naam herinner ik me niet.

(Achterkant; rechterzijde) En hierbij 10 rezana's met de brief.

We zijn Loeka al tegengekomen bij de behandeling van het jubileumnummer 1000, waar ook nr. 1009 is opgevoerd (p. 52). In die laatste brief is hij samen met Ivan de afzender van een bericht aan Snovid. Zoals al gezegd, zou Ivan de broer van Loeka kunnen zijn en Snovid hun vader.

De hoofdtekst is duidelijk. Loeka richt zich tot zijn vader (Snovid?) met het verzoek om geld te innen van 'de knecht', die nog niet betaald heeft voor geleverde goederen. Als hij ontkent, moet Loeka's vader hem confronteren met de feiten en bovendien het verschuldigde bedrag verhogen met een grivna.

Op de andere kant van de berkenbast vinden we drie notities in hetzelfde handschrift. De eerste, 'Van Loe', lijkt het afgebroken begin te zijn van de hoofdtekst, hetgeen doet denken aan nr. 907 (p. 59), waar met ' $\mathrm{Er}$ is van hem' hetzelfde aan de hand is. Blijkbaar is Loeka zijn brief eerst op de ene kant van de berkenbast begonnen en heeft hij zich vervolgens bedacht.

De tweede notitie gaat klaarblijkelijk over de degene die de brief brengt, Goimer. Deze komt samen met zijn vrouw (van wie Loeka de naam is vergeten!) en is afkomstig uit Tsjernigov. Deze stad ligt 
in het noordoosten van het huidige Oekraïne (Tsjernihiv), ongeveer achthonderd kilometer ten zuiden van Novgorod. Tsjernigov wordt al vroeg vermeld in de kronieken en was ten tijde van brief nr. 1004 onderdeel van het gelijknamige machtige vorstendom.

Loeka introduceert de koerier Goimer op een manier alsof hij naast zijn vader staat: 'En dit is Goimer'. Hij richt zich dus niet op het moment van het schrijven van de brief, maar op het leesmoment van de ontvanger. Hetzelfde type oriëntatie hebben we gezien in de vorige brieven, nr. 735 ('Geef aan deze dienaar'), nr. 739 ('Geef aan deze diaken') en nr. 879 ('Geef aan deze' en 'wat hij heeft gezegd').

Overigens gebruikt Loeka in een andere brief aan zijn vader, Novgorod nr. 1006 (derde kwart twaalfde eeuw), precies dezelfde formulering als in nr. 879. Op de voorkant schrijft hij: x Van Loeka een brief aan vader. Hierbij de vracht voor achttien koena's en 2 grivna's, inclusief het transport. Op de achterkant volgt een instructie aan zijn vader over de koerier: En geef aan deze acht nogata's.

De derde notitie op de achterkant van nr. 1004, 'En hierbij 10 rezana's met de brief', zou ook wel eens betrekking kunnen hebben op de vergoeding voor de koerier, waarbij we dan moeten aannemen dat Loeka al vooruitbetaald heeft. Zeker weten doen we dat natuurlijk niet, want het zou ook om een heel andere transactie kunnen gaan. 
'En geef het aan Michalj'

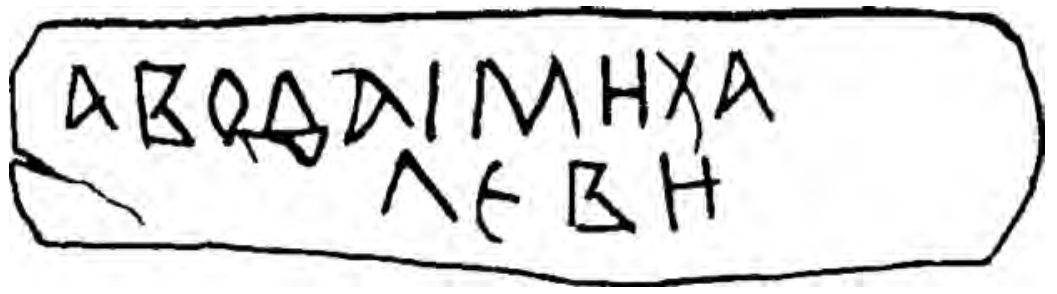

Novgorod nr. 79, ca. 1180-1200

En geef (het) aan Michalj.

Op de afbeelding is te zien dat we met een volledig document te maken hebben. Net als in het geval van de vorige brieven (nrs. 735, 739,879 en 1006) zouden we kunnen denken dat het om een instructie gaat aan de ontvanger van de brief, om iets te geven aan Michalj. Die Michalj zou dan de koerier zelf kunnen zijn, of een derde persoon in de transactie. In een dergelijk scenario zouden we echter met name bij dit soort instructies verwachten dat de naam van de geadresseerde wordt genoemd, zoals in de vier eerdergenoemde brieven gebeurt.

Het ontbreken van de naam van degene die iets aan Michalj moet geven doet vermoeden dat het in het geval van $\mathrm{nr}$. 79 gaat om een memo aan de koerier zelf, dat hoort bij de spullen die hij moet afleveren bij Michalj. 
'Petr is naar jou vertrokken'

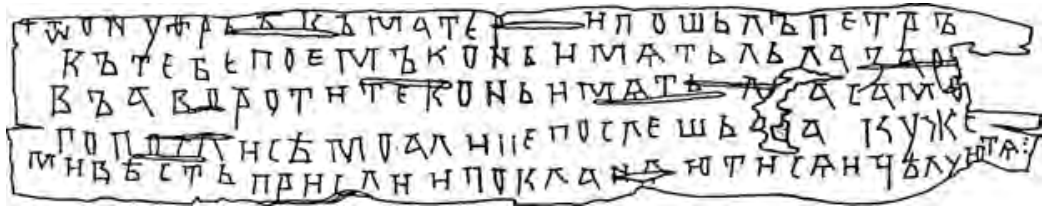

Torzjok nr. 10, ca. 1200-1220

+ Van Onoefrija aan moeder. Petr is naar jou vertrokken, met Lazars paard en mantel. Geef het paard en de mantel terug, en stuur hem zelf hierheen. Als je hem niet stuurt, stuur me dan hierover een bericht. En ik buig voor je en groet je.

In Torzjok, gelegen in de buurt van Tver (zie de kaart op p. 20), iets minder dan driehonderd kilometer ten zuidoosten van Novgorod, zijn negentien berkenbastteksten opgegraven.

Het is natuurlijk mogelijk dat Petr op weg is naar Onoefrija's moeder en dat Onoefrija na zijn vertrek apart een briefje stuurt met verdere instructies. Het is echter veel eenvoudiger om te veronderstellen dat Petr het briefje heeft meegenomen en dus zelf de koerier is. De verledentijdsvorm in 'Petr is naar jou vertrokken' staat een dergelijke interpretatie niet in de weg. Ook in het Nederlands kun je bijvoorbeeld 'ik ben vertrokken / weg' zeggen wanneer je met je jas aan nog in de deuropening staat. In deze berkenbastbrief kunnen we ons voorstellen dat Petr op het punt staat te vertrekken, dat hij 'zo goed als' vertrokken is.

In het vervolg van de brief draagt Onoefrija zijn moeder op om het paard en de mantel aan Lazar te bezorgen en Petr zelf naar hem terug te sturen. Mocht dat laatste niet gebeuren, dan moet ze dat aan hem laten weten. 
'Opdat noch jij noch Pavel een slechte naam krijgt'

Novgorod nr. 745, ca. 1100-1120

Van Pavel uit Rostov aan Bratonezjko. Als het schip van de Kiëver (al) is gestuurd, informeer dan de vorst daarover, opdat noch jij noch $\mathrm{Pa}$ vel een slechte naam krijgt.

De stad Rostov ligt zo'n vijfhonderd kilometer ten zuidoosten van Novgorod. De vorst die geïnformeerd moet worden is gezien de datering vorst Mstislav de Grote, die van 1088 tot 1117 met een korte onderbreking over Novgorod heerste.

De naam van de afzender van de brief komt in de tekst zelf terug in de derde persoon. Dit doet denken aan nr. 422 ('Van Mestjata aan Gavsja ... En Mestjata groet jullie'; zie p. 137). Ook hier kunnen we ons voorstellen dat het de koerier is geweest die de brief heeft geschreven, waarbij hij het slot heeft opgetekend vanuit zijn eigen perspectief als mondelinge overbrenger van het bericht. Vanuit dat perspectief is Pavel inderdaad een derde persoon. Het slot van de brief is dus weergegeven in de directe rede van de koerier.

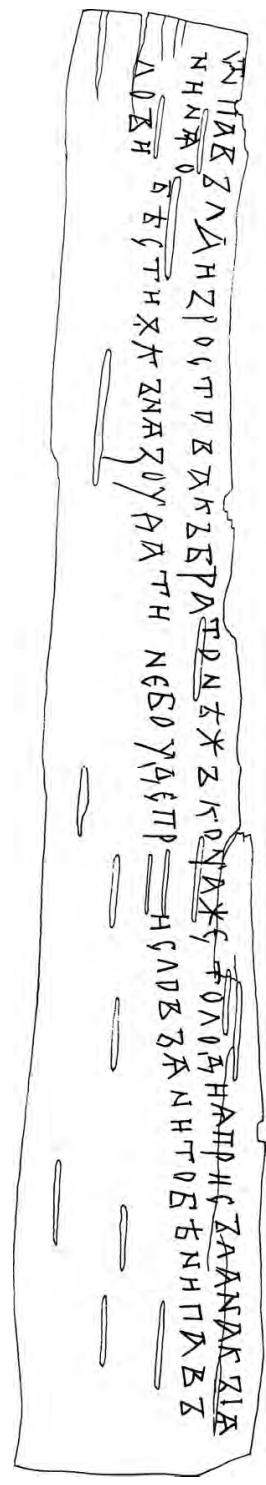




\section{'Kosnjatins brief'}

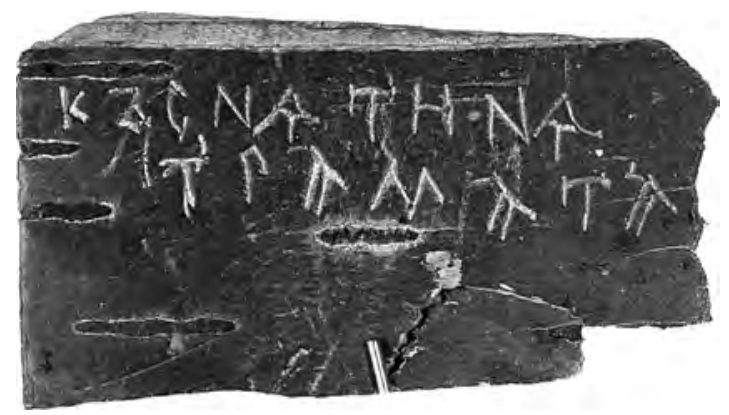

Novgorod nr. 397, ca. 1180-1200

Kosnjatins brief.

Als we naar de foto kijken, zien we dat deze berkenbast geen fragment is van een langere brief: zowel onder de twee woorden als rechts ervan volgt geen verdere tekst.

Wat is het nut van deze 'brief'? Is het een label dat ergens bijhoort? Bij een andere brief, of bij een officieel document dat was opgeslagen? Dat lijkt nogal vreemd. Met het oog op de mondelinge factor in de communicatie op berkenbast en de speciale rol van de koerier, is het beslist niet speculatief om te veronderstellen dat we hier te maken hebben met een 'rudimentaire' schriftelijke autorisatie voor de koerier die mondeling een boodschap van Kosnjatin overbrengt.

Nr. 397 staat niet op zichzelf. Vergelijkbaar is Novgorod nr. 443 (ca. 1200-1220), een complete brief met alleen de namen van de afzender en de twee geadresseerden:

Van Dmitr aan Flar en aan Nesdila.

Het is mogelijk dat we hier inder-

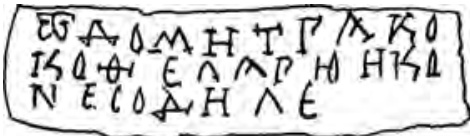
daad te maken hebben met een label dat ergens bijhoort, bijvoorbeeld een zending van Dmitr. We kunnen echter ook aan een scenario denken als dat bij nr. 397. 


\section{'Ga het in Pskov meedelen'}

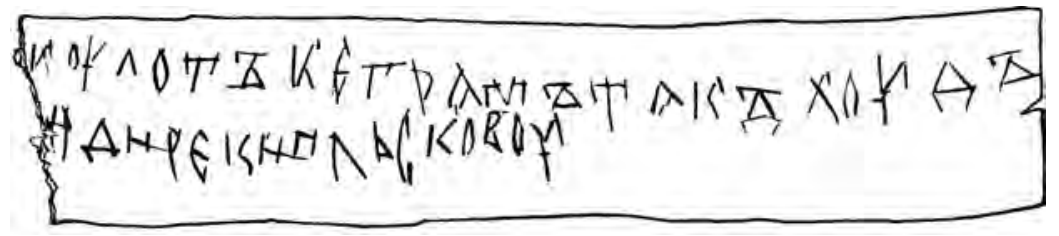

Novgorod nr. 656, ca. 1160-1180

(Van) Koelotka een brief aan Choedo(ta). Ga het in Pskov meedelen.

Afgezien van een kleine lacune aan de linkerkant van de berkenbast, gaat het hier om een volledige brief, die behalve uit een aanhef slechts uit drie woorden bestaat: idi 'ga!', reki 'zeg!' en pl'skovu 'naar Pskov'.

Als we uitgaan van een scenario waarbij Koelotka een brief meegeeft aan een (anonieme) koerier met een instructie voor Choedota, dan vragen we ons af hoe die laatste kan weten wat hij moet gaan vertellen in Pskov. Het is mogelijk dat hij daarvan eerder op de hoogte is gebracht en dat de brief alleen het sein is dat het nu zover is om 'het' te gaan meedelen. Het is evenwel ook mogelijk dat Koelotka de precieze instructies aan de koerier overlaat, die ze mondeling aan Choedota overbrengt.

Een ander scenario is dat we te maken hebben met een mandaatbrief: Choedota is zelf de koerier die schriftelijk in Pskov kan aantonen dat Koelotka hem opdracht heeft gegeven om 'het' te vertellen. 
'Wij allen zullen jullie woord niet vergeten'

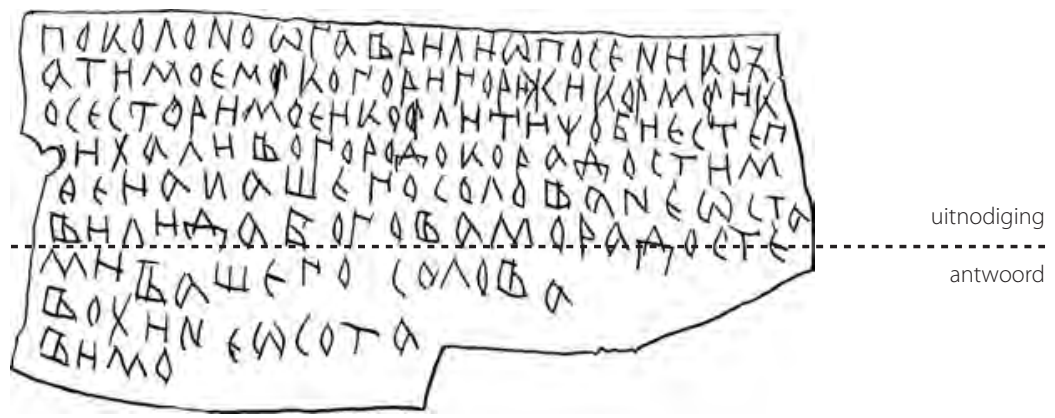

Novgorod nr. 497, ca. 1340-1360

Groet van Gavrila Postnja aan mijn zwager, peetoom Grigorja en aan mijn zuster Oelita. Mogen jullie naar de stad komen tot mijn genoegen. En mogen jullie ons woord niet vergeten. God geve jullie vreugde. Wij allen zullen jullie woord niet vergeten.

In de tekst wordt verwezen naar 'de stad', waarmee op berkenbast Novgorod bedoeld wordt (zie Staraja Roessa 40, p. 97, die inhoudelijk veel op nr. 497 lijkt). De brief is dus vandaar verstuurd, maar blijkbaar ook teruggekomen, want hij is opgegraven in Novgorod. Waarom is dat gebeurd? En hoe moeten we de laatste zin van de brief interpreteren: een positief antwoord van de afzender op een andere, eerdere uitnodiging van de kant van de geadresseerden?

Het simpelste scenario voor nr. 497 is dat de laatste zin het antwoord bevat op de uitnodiging van Gavrila Postnja. Aangezien de brief in een en hetzelfde handschrift is, moeten we ervan uitgaan dat het de koerier is geweest die eerst de uitnodiging in Novgorod heeft opgetekend, vervolgens daarmee naar de familieleden van Gavrila Postnja is gegaan, daar ter plekke hun antwoord vlak onder de uitnodiging heeft opgeschreven, en toen de brief heeft teruggebracht naar Novgorod. 


\section{Heterogene brieven}

\section{'En jij, Nester, stuur me een brief'}

Novgorod nr. 358, ca. 1340-1360

Groet aan mevrouw, moeder. Ik heb je 20 eekhoornvellen gestuurd met de stadhouder z'n (man) Manoeil. En jij, Nester, stuur me een brief over de helm, (om me te laten weten) met wie je hem zult sturen. En zorg, wanneer je in Torzjok bent aangekomen, voor het voeren van de paarden met goede hooi. Doe je eigen slot op de graanschuur. En blijf op de dorsvloer wanneer er gedorst wordt. En laat de paarden voeren met haver in je bijzijn en in voldoende mate. En in de schuur rogge ... weeg het opnieuw en ook de haver. En laat me weten wie er rogge of haver nodig heeft ...

We kennen de persoon van wie deze bijna complete brief - in hetzelfde handschrift als de volgende brief, nr. 354 - afkomstig is: Ontsifor Loekinitsj, telg uit het vooraanstaande geslacht van de Misjinitsji (zie p. 166). Ontsifor was stadhouder van Novgorod in 1350-1354 en stierf in 1367. Hij komt niet alleen meerdere keren voor op berkenbast (zowel als afzender als geadresseerde), maar ook in de kronieken.

Hoewel Ontsifor in de aanhef alleen zijn moeder noemt, is de brief niet alleen aan haar gericht, maar ook expliciet en zelfs voornamelijk aan Nester. Deze is blijkbaar een (ondergeschikte) manager van de familie, die door Ontsifor met name wordt aangesproken op zaken die hij in Torzjok moet gaan regelen.

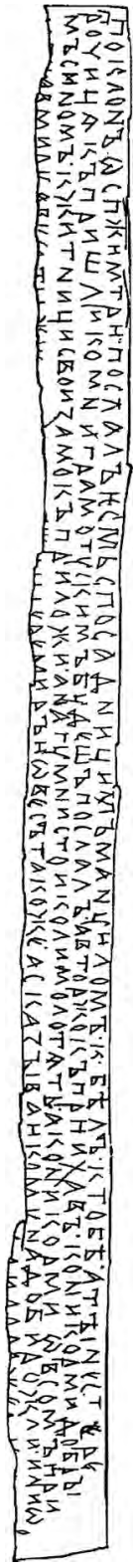




\section{'Draag Nester op om een roebel bijeen te brengen'}
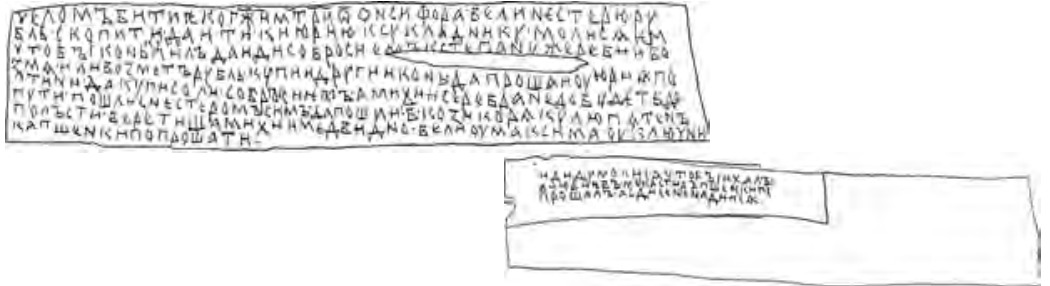

Novgorod nr. 354, ca. 1340-1360

(Binnenkant) Verzoek aan mevrouw, moeder, van Ontsifor. Draag Nester op om een roebel bijeen te brengen en naar compagnon Joeri te gaan. Vraag hem een paard te kopen. En ga met Obrosi naar Stepan voor mijn aandeel. Als hij de roebel aanneemt, koop ook een tweede paard. En vraag Joeri om een halve roebel en koop met Obrosi zout. En als hij het bont en het geld niet weet te krijgen voor de reis, stuur het dan hierheen met Nester. En stuur twee ijzeren drievoeten, een vork, brandijzers, vilten kleden, linnen omslagen, zakken en een berehuid. Draag op om Maksim, de beheerder, om gierst (?) te vragen.

(Buitenkant) En vraag grootvader om naar het Joerjev-klooster te gaan, om gierst (?) te vragen. En hier is geen hoop (om het te krijgen).

Deze brief lijkt erg op de vorige (nr. 358): hij is weer afkomstig van Ontsifor, weer gericht aan zijn moeder, en gaat weer over zaken die Nester moet gaan regelen. Maar wat moet hij precies regelen? Alleen dat wat in de zin 'Draag Nester op ...' staat? Vraagt Ontsifor aan zijn moeder om alle overige instructies uit te voeren? Moet zij zelf met Obrosi op pad voor een paard en voor zout? Dat is weinig aannemelijk. Het ligt eerder voor de hand dat het stuk 'Vraag hem een paard te kopen ... en koop met Obrosi zout' rechtstreeks is gericht aan Nester (waarbij 'hem' dus niet op Nester slaat, maar op Joeri). Dus, terwijl Nester in nr. 358 expliciet wordt aangesproken ('En jij, Nester'), gebeurt dit hier impliciet. 
'Geef 6 koena's en een grivna aan Vysjata'

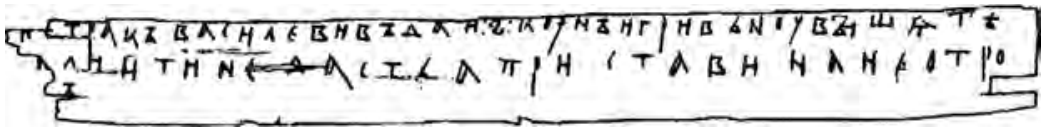

Staraja Roessa nr. 15, ca. 1140-1160

Van Petr aan Vasilj. Geef 6 koena's en een grivna aan Vysjata. Als hij ze niet geeft, stuur dan een deurwaarder op hem af.

Deze brief doet wat thema en opbouw betreft sterk denken aan nr. 241 (p. 57). Maar wat staat hier eigenlijk? Wie is de 'aangesproken persoon' in de tweede zin? Wie is 'hij' in de derde zin? Na de vondst van de brief, in 1985, ging men ervan uit dat in de tekst ongeveer de volgende situatie wordt beschreven: Petr had blijkbaar een schuld aan Vysjata die daarvoor een onderpand had genomen. Vysjata krijgt nu de schuld terug (de 6 koena's en de grivna), maar moet wel het onderpand afgeven. Als hij dat niet doet, dan dreigt Petr met de deurwaarder.

Een dergelijke ingewikkelde uitleg is overbodig wanneer we aannemen dat in de brief twee personen direct worden aangesproken: Vasilj, die in de tweede zin een rechtstreekse opdracht krijgt, en Vysjata, die in de derde zin een rechtstreeks mandaat krijgt. Dus: 'Vasilj: geef 6 koena's en een grivna aan Vysjata. Vysjata: Als Vasilj ze niet geeft, stuur dan ....

Petr schrijft in wezen een brief waarin hij Vasilj en Vysjata beiden aanspreekt, maar dan wel een voor een, alsof hij tegenover hen staat en zich eerst tot de een richt en dan tot de ander. Van Vasilj eist Petr dat hij over de brug komt met het geld en aan Vysjata geeft hij toestemming om zo nodig een deurwaarder in te schakelen.

In dit scenario hebben we te maken met een mandaatbrief en is het goed mogelijk dat Vysjata de koerier is: hij heeft de brief van Petr meegekregen en laat nu aan Vasilj zien dat hij het recht heeft om stappen te ondernemen wanneer er niet wordt betaald. 
'En jij, dorpsoudste, moet het verzamelen'

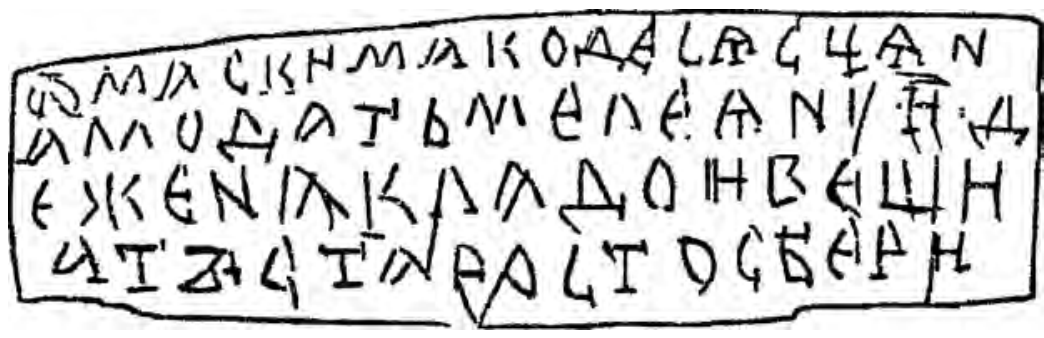

Novgorod nr. 253, ca. 1360-1380

Van Maksim aan de inwoners van Desjatkoje. Jullie moeten aan Meljan acht maten (graan), de rente en het graan (zelf) geven. En jij, dorpsoudste, moet het verzamelen.

De vertaling 'de inwoners van Desjatkoje' is niet helemaal zeker. Desjatkoje is afgeleid van het woord voor 'tien' en zou dus het dorp 'Tienen' kunnen betekenen, maar er zou ook kunnen staan: 'de inwoners van de (specifieke) groep van tien dorpen'.

We kennen de afzender Maksim ook uit andere brieven, zoals nr. 370 (p. 72 ) en nr. 177 (p. 152). In nr. 370 wordt hij samen met zijn broer Joeri aangeschreven. Hun vader was Ontsifor, die we in nr. 354 (p. 149) en nr. 358 (p. 148) zijn tegengekomen.

Het is duidelijk dat Maksim in deze brief eerst de dorpsbewoners aanspreekt en vervolgens de dorpsoudste (starosta). Minder duidelijk is wat de verhouding is tussen Meljan en de dorpsoudste: moet de laatste de spullen verzamelen en vervolgens aan Meljan geven?

Met het oog op de communicatieve structuur van andere berkenbastbrieven die we al zijn tegengekomen, is het heel goed denkbaar dat Meljan en de dorpsoudste een en dezelfde persoon zijn. Maksim heeft Meljan een mandaatbrief meegegeven die hij aan de bewoners kan laten zien: ze moeten graan en rente afstaan en Meljan, de dorpsoudste, is door Maksim gemachtigd om de spullen te innen. 
'Geef de sleutels aan Foma'

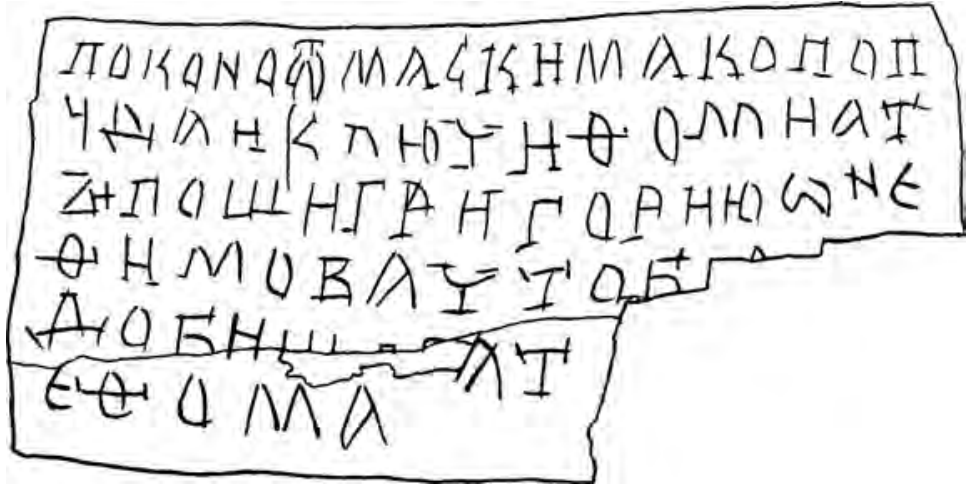

Novgorod nr. 177, ca. 1360-1380

Groet van Maksim aan de priester. Geef de sleutels aan Foma. En jij, stuur Grigori Onfimov. Als er wat nodig is, ... Foma.

Weer hebben we te maken met een brief van Maksim Ontsiforovitsj (vergelijk de vorige, nr. 253, die wat structuur betreft op deze lijkt). Het eind van de brief is niet helemaal bewaard gebleven.

In de derde zin staat expliciet het voornaamwoord 'jij' ('En jij, stuur ...), net zoals in de laatste zin van nr. 253 ('En jij, dorpsoudste ...). Blijkbaar signaleert dat expliciete 'jij' ook hier dat Maksim zijn referentieperspectief wijzigt en dat hij zich niet meer tot de priester richt. Dan verwacht je dat met 'jij' Foma wordt bedoeld, die van Maksim de instructie krijgt om Grigori te sturen.

Het is goed mogelijk dat Grigori gestuurd moet worden om de sleutels voor Foma bij de priester op te halen. In dat geval zouden we te maken hebben met een mandaatbrief die Grigori kan laten zien aan de priester om de sleutels in naam van Foma overhandigd te krijgen.

In het laatste stuk van de brief wordt de naam Foma vermeld. Dit duidt erop dat Maksim zich weer richt tot de priester (bijvoorbeeld: 'Als er wat nodig is, dan zal Foma het bezorgen'). 
'En jullie moeten de inner een koena de man geven'

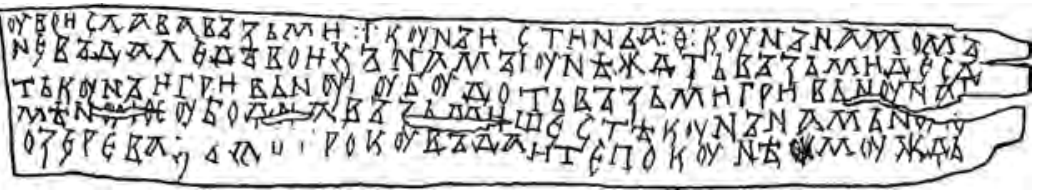

Novgorod nr. 509, ca. 1160-1180

Van Voislav neem tien koena's van het kapitaal en vijf koena's als rente; hij heeft twee termijnen geen rente afgegeven. Van Nezjata neem tien koena's en een grivna. Van Boedota neem een grivna rente. Van Bojan in Ozerevy neem zes koena's rente. En jullie moeten de inner een koena de man geven.

Voor het woord 'inner' in de laatste zin staat in het Russisch otrok, dat we al eerder zijn tegengekomen (bijvoorbeeld in nr. 241, p. 57, en in Staraja Roessa nr. 15, p. 150). Daar is het woord met het oog op de meer juridische context vertaald als 'deurwaarder', terwijl hier het algemenere 'inner' (blijkbaar van betalingen) eerder op z’n plaats lijkt.

De brief bestaat uit vijf zinnen: in de eerste vier wordt een niet genoemde persoon opgedragen om geld te innen van Voislav, Nezjata, Boedota en tot slot Bojan in Ozerevy (een plaats in het Novgorodse land). In de laatste zin moeten meerdere personen - 'jullie' - ieder een koena geven aan de inner.

Nr. 509 is het gemakkelijkst te begrijpen als een mandaatbrief die de inner kan laten zien aan de vier betalingsplichtigen. De eerste vier zinnen houden de instructies in die hij heeft meegekregen, terwijl de laatste is bedoeld voor Voislav, Nezjata, Boedota en Bojan, die hem ieder een koena moeten geven voor het ophalen van het geld.

Overigens duiden enkele correcties in de laatste zin erop dat de schrijver eerst 'En de inner moet nemen ...' wilde componeren, maar zich toen bedacht en de zin herformuleerde door rechtstreeks de vier betalingsplichtigen aan te spreken. 


\section{'En geef ze aan Semen Flarev'}

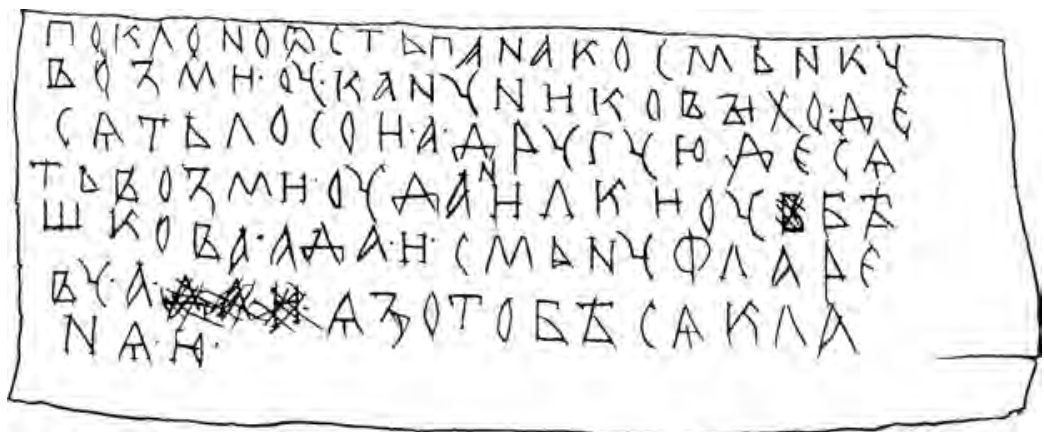

Novgorod nr. 186, ca. 1360-1380

Groet van Stepan aan Semenko. Neem van de Kanoennikovs tien zalmen, en neem er nog eens tien van Danilka Besjkov. En geef ze aan Semen Flarev. En ik groet jou.

Het is zonder meer mogelijk om deze brief simpelweg op te vatten als een instructie aan Semenko om op twee plekken - bij de Kanoennikovs en bij Danilka Besjkov - zalmen op te gaan halen en deze vervolgens bij Semen Flarev af te leveren. Met het oog op andere berkenbastteksten met vergelijkbare instructies (zie bijvoorbeeld nr. 253, p. 151, en de vorige, nr. 509), kunnen we ook aan een andere communicatieve structuur denken: Semenko en Semen Flarev zijn een en dezelfde persoon. In dat geval hebben we te maken met varianten op diens voornaam: Semenko naast Semen (met de toevoeging Flarev). Zoiets is in het middeleeuws Russisch heel normaal: naar Ivan kan ook worden verwezen met Ivanko (zie nr. 907, p. 59, en ook p. 161), naar Petr met Petrok en naar Jakoen met Jaksja (zie p. 162), naar Marena met Marenka (zie nr. 955, p. 90), enz.

In het alternatieve scenario richt Stepan zich in de zin 'En geef ze aan Semen Flarev' rechtstreeks aan de twee partijen die de zalmen 
moeten afgeven en is nr. 186 een mandaatbrief die Semen(ko) kan meenemen.

Op de afbeelding is te zien dat in de voorlaatste regel drie letters zijn doorgekrast. Daar stond de gebiedende wijs 'geef'. De schrijver heeft in eerste instantie geschreven: 'En geef (ze) aan Semen Flarev. En geef'. Vervolgens heeft hij 'geef' doorgestreept en is hij met 'En' doorgegaan: 'En ik groet jou'. Je zou kunnen denken dat hij eerst beide partijen afzonderlijk wilde aanspreken (de Kanoennikovs en daarna Danilka), maar vervolgens inzag dat één keer 'En geef' voldoende duidelijk moest zijn. 


\section{'En geef het geld aan Zacharja'}

Novgorod nr. 420, ca. 1240-1260

Van Panko aan Zacharja en aan Ogafon. Ik heb veertig beverhuiden aan Miljata verkocht voor tien zilvergrivna's. Wanneer jij het geld krijgt, geef dan de beverhuiden af. En geef het geld aan Zacharja.

We hebben al eerder brieven gezien waar in de aanhef twee geadresseerden worden vermeld, maar in de brief zelf sprake is van één persoon (zie nr. 370, p. 72, en Staraja Roessa nr. 39, p. 46). Dat lijkt ook hier het geval te zijn, en met het oog op de laatste zin schijnt Panko zich tot Ogafon te richten. Het geeft echter te denken dat hij in zijn aanhef eerst Zacharja noemt. Het is verder vreemd dat deze überhaupt wordt geadresseerd: hem wordt immers niets gevraagd en wat kan het hem schelen op wat voor manier het geldbedrag - dat Panko hem blijkbaar verschuldigd is - is verkregen?

Het wordt echter wel begrijpelijk dat Zacharja in de aanhef wordt genoemd, en wel als eerste, wanneer we veronderstellen dat het Zacharja is die namens Panko de aan Miljata verkochte beverhuiden moet afleveren en het geld voor hem moet incasseren. Dat wil zeggen, wanneer we lezen: 'Zacharja: wanneer jij het geld krijgt, geef dan de beverhuiden af'. In de laatste zin richt Panko zich vervolgens tot Ogafon, die namens Miljata handelt en het geld moet geven om de deal rond te maken.

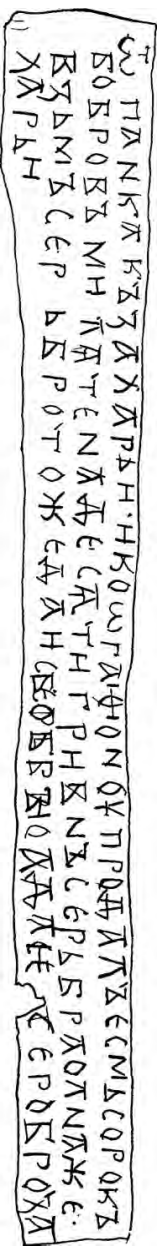

Panko construeert de brief zo dat eerst de deal tussen hem en Miljata aan de uitvoerders van beide partijen wordt gecommuniceerd. Vervolgens instrueert hij zijn eigen uitvoerder, Zacharja, die de brief als volmacht kan meenemen naar en laten zien aan de uitvoerder van de tegenpartij, Ogafon. 
'Als je lang moet blijven, stuur een bericht'

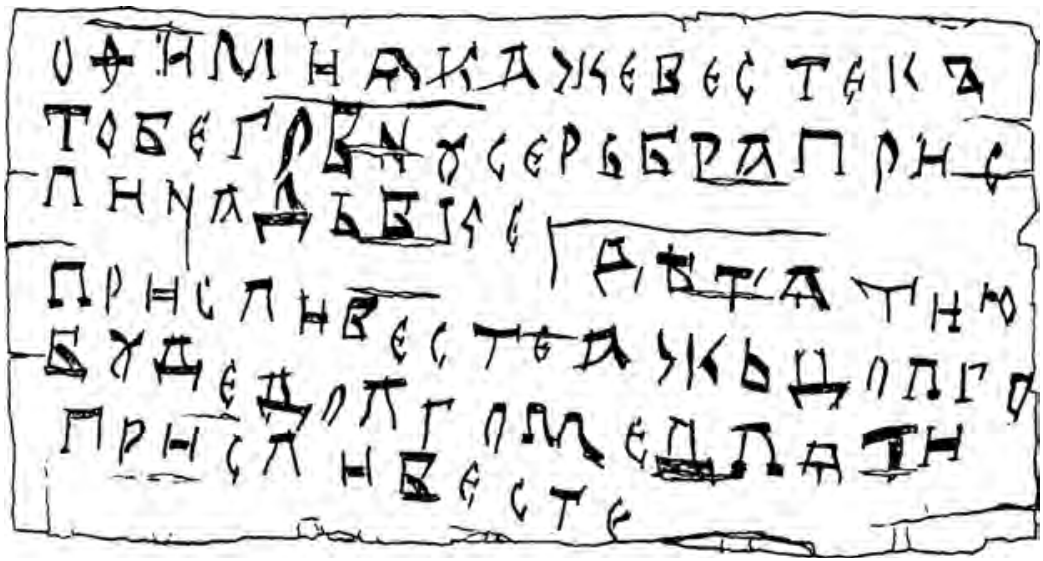

Novgorod nr. 771, ca. 1300-1320

Ofimja deelt een bericht aan jou mee: stuur een zilvergrivna voor het slavinnetje. | Met het kind stuur een bericht; als je lang moet blijven, stuur een bericht.

Zoals op de tekening goed te zien is, is de brief grafisch in twee stukken opgedeeld. Na het midden van de derde regel is een hoekige lijn getrokken. Daarna gaat de tekst op een iets lager niveau verder met 'Met het kind .... Het stuk vóór de afscheiding (met het ongebruikelijke 'aan jou' in de aanhef, in plaats van de vermelding van de naam van de geadresseerde), lijkt een schriftelijke weergave te zijn van de woorden van Ofimja die de koerier mondeling moet overbrengen. De brief hoefde dus niet overhandigd te worden.

De duidelijke afscheiding geeft aanleiding tot de hypothese dat het tweede stuk van de brief losstaat van het eerste. In eerste instantie denken we dan aan een memo van Ofimja aan de koerier met verdere instructies. Deze moet een bericht sturen 'met het kind' in het geval het langer duurt om het geld te krijgen. 
'En als hij begint te vragen voor vrouw of zoon ...'

Novgorod nr. 406, ca. 1360-1380

... en vissen en boter en kazen, en dat is de pachtsom voor 3 jaar

... En wij verzoeken je nederig, heer Ofonos. En de tribuut ken je: 3 martervellen voor 3 jaar. En als hij begint te vragen voor vrouw of zoon, dan voor de vrouw 2 eekhoornvellen en voor de zoon een eekhoornvel.

Deze brief, waarvan het begin ontbreekt, toont grote gelijkenis met nr. 136 (p. 74). Ook hier lijken we te maken te hebben met een overeenkomst tussen boeren en hun landheer over de betaling van pacht en tribuut, waarbij op het laatst ook de familieleden van de landheer genoemd worden (vergelijk 'aan de kinderen ieder een eekhoornvel' in nr. 136). In tegenstelling tot nr. 136 wordt hier de naam van de landheer expliciet genoemd, en wel in de tweede persoon: 'En wij verzoeken je nederig. Tegelijkertijd is het aannemelijk dat 'hij' in 'En als hij begint te vragen voor vrouw of zoon' ook op die landheer, Ofonos, slaat.

Als dat inderdaad zo is, dan moet de brief uit twee verschillende communicatieve delen bestaan: het eerste is gericht aan Ofonos en het tweede, vanaf 'En als hij begint te vragen' aan de koerier, net als in de vorige brief, nr. 771. De koerier is tevens afgevaardigde van de boeren en krijgt in het tweede deel nadere instructies wanneer Ofonos meer begint te vragen. Een dergelijke interpretatie veronderstelt uiteraard dat de brief werd voorgelezen aan Ofonos en niet aan hem werd overhandigd. 
'Goven heeft het gezegd vlak voor zijn dood'

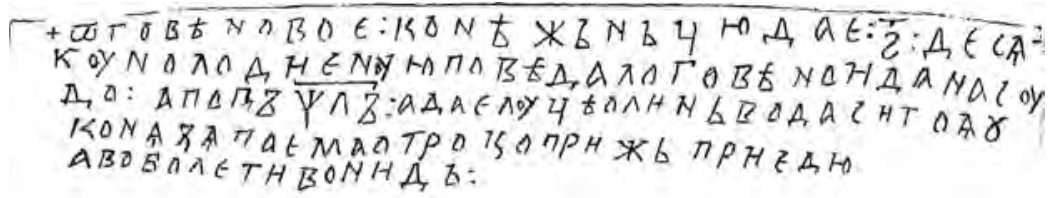

Zvenigorod nr. 2, ca. 1120-1140

+ Van Govens weduwe aan Nezjenets. Geef zestig koena's voor het schip. Goven heeft het gezegd vlak voor zijn dood, en de priester heeft het opgetekend. Geef ze aan Loeka. Als je ze niet geeft, dan neem ik bij de vorst een deurwaarder en kom ik samen met hem; dat komt je dan op meer te staan.

Zvenigorod (Zvenyhorod) ligt in Galicië, helemaal in het westen van het huidige Oekraïne, meer dan duizend kilometer ten zuidwesten van Novgorod. In Zvenigorod zijn in totaal drie berkenbastteksten gevonden.

In de Nederlandse vertaling ziet de tekst er rechttoe rechtaan uit. Problematisch is echter in het Russisch de vorm 'neem' in 'dan neem ik bij de vorst een deurwaarder'. Grammaticaal is het met enige moeite mogelijk om in 'neem' een vrouwelijke vorm te zien. Die zou dan slaan op de enige vrouw die in de tekst wordt genoemd: Govens weduwe.

Er is taalkundig gezien zeker iets voor te zeggen dat 'neem' niet op een vrouwelijke maar op een mannelijke persoon moet slaan, en dan verandert de communicatieve interpretatie van de tekst: 'neem' slaat op Loeka, die in naam van Govens weduwe handelt. Hij is degene die terugkomt met een deurwaarder als Nezjenets niet betaalt.

De perspectiefwisseling van Govens weduwe naar Loeka is goed mogelijk wanneer we aannemen dat Loeka de koerier en schrijver is geweest van de brief. 


\section{Sociale netwerken}

\section{Rondom Ivan en Nezjata}

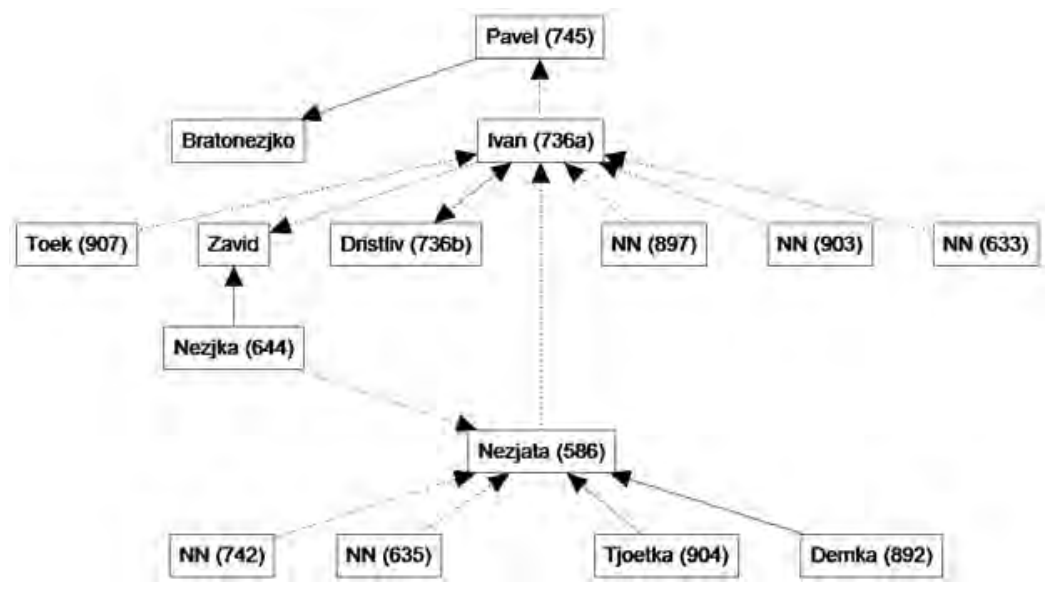

Achter een naam die op berkenbast vaker voorkomt, gaat in meerdere gevallen een en dezelfde persoon schuil. Uiteraard kan dat niet altijd met zekerheid bepaald worden, vooral niet wanneer het om hele gewone namen gaat als Ivan, Petr of Anna. Echter, wanneer in dezelfde bodemlaag en op dezelfde plek meerdere brieven gevonden worden van of gericht aan een en dezelfde naam, en wanneer de inhoud van die brieven een coherent beeld oplevert van de bezigheden van de persoon die deze naam draagt, dan begint identificatie voor de hand te liggen. Dit is natuurlijk bijna met zekerheid het geval wanneer we meerdere brieven van dezelfde afzender en in hetzelfde handschrift hebben.

Identificatie van personen op berkenbast kan ook plaatsvinden op basis van informatie uit andere historische bronnen, met name de Eerste Novgorodse Kroniek, zoals we al gezien hebben bij de behandeling van meerdere brieven in dit boek. Verder helpt het ook wan- 
neer we proberen te achterhalen of afzenders en ontvangers deel uit maken van hetzelfde netwerk van correspondenten. Die zijn er wel degelijk op berkenbast; kleinere, maar ook zeer uitgebreide, waarbij tientallen personages met elkaar in een zakelijke, persoonlijke of familierelatie blijken te staan.

In het oudste netwerk dat hier is weergegeven, uit het eind van de elfde en begin van de twaalfde eeuw, wordt de relatie tussen verschillende personen aangeduid met pijlen. Een ononderbroken pijl geeft aan wie aan wie schrijft; pijlen met stippellijnen worden gebruikt wanneer iemand in andermans brief wordt genoemd. Dus, Pavel schrijft een brief aan Bratonezjko (nr. 745, p. 144) en wordt zelf genoemd door Ivan in diens brief aan Dristliv (nr. 736, p. 49: 'Als jij de rente van Pavel hebt genomen ...). (Dristliv antwoordt Ivan op de achterkant van Ivans brief.)

Alle twaalf brieven uit het oudste netwerk zijn gevonden in de Ljoedin wijk en duidelijk is te zien dat twee personen centraal staan: Ivan en Nezjata. We zijn Ivan al tegengekomen in nr. 907 (p. 59), waar hij Ivanko wordt genoemd (vergelijk p. 154); hij kan geïdentificeerd worden als Ivan Pavlovitsj (d.w.z. 'Ivan, zoon van Pavel'; zie nr. 745, p. 144), die in 1134-1135 stadhouder van Novgorod was.

Nezjata is in het netwerk met Ivan verbonden door nr. 586 ('de jas van Ivan', p. 42) en via nr. 644 (p. 94), waarin Nezjka zich richt aan Zavid - die door Ivan wordt genoemd in nr. 736 - en waarin Nezjka ook Nezjata ter sprake brengt. Uit nr. 644 blijkt dat Nezjka de zus is van Nezjata en Zavid. De structuur van de naam Bratonezjko ('Broer-Nezjko') in nr. 745 doet vermoeden dat ook hij lid was van de familie. 


\section{Rondom Petr, Jaksja en Marena}

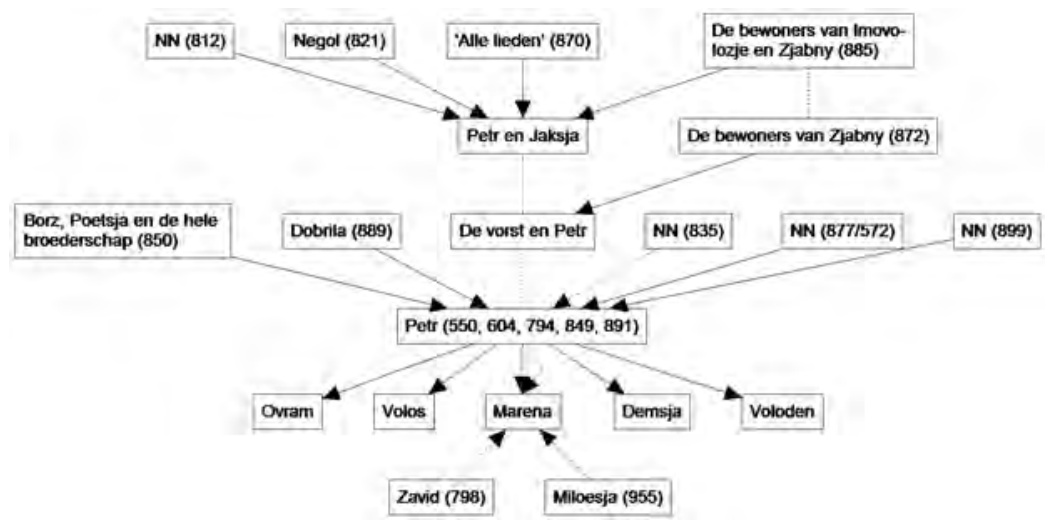

Het hier afgebeelde netwerk uit de periode ca. 1125-1175 concentreert zich met name rondom een zekere Petr, ook wel Petrok genoemd op berkenbast. Bronnenonderzoek heeft uitgewezen om wie het precies gaat: de hooggeplaatste bestuurder en bojaar Petr Michalkovitsj. Hij was hoogstwaarschijnlijk getrouwd met Marena, aan wie hij brief nr. 794 richt en die hij noemt in zijn brief aan Demsja (nr. 849). In dit boek treedt Marena op als geadresseerde van nr. 955 (p. 90).

Dat Petr Michalkovitsj een centrale rol speelde in de Novgorodse administratie en rechtspraak blijkt uit het relatief grote aantal brieven dat hij ontvangt en verstuurt, en uit de inhoud ervan (zie bijvoorbeeld nr. 550, p. 69). In de fragmentarisch overgeleverde brief Novgorod nr. 872 (ca. 1140-1160) wordt hij zelfs aangeschreven samen met de vorst: Van de inwoners van Zjabny aan de vorst en aan Petrok....

In verschillende andere brieven wordt Petr geadresseerd samen met Jaksja, die geïdentificeerd kan worden als de stadhouder Jakoen 
Miroslavitsj. Overigens, ook onder de recente vondsten uit 2010 (vergelijk p. 52) treffen we deze Jaksja aan, zoals in Novgorod nr. 999 (tweede helft twaalfde eeuw): Van Loeka aan vader. Laat zaaien bij Toedor. En geef 2 grivna's aan Jaksja ....

Petr moet de gewoonte gehad hebben om zijn brieven te dicteren, want nr. 550 (zie p. 69), 604, 794, 849 en 891 zijn alle in een verschillend handschrift geschreven. 


\section{Rondom Grigori}

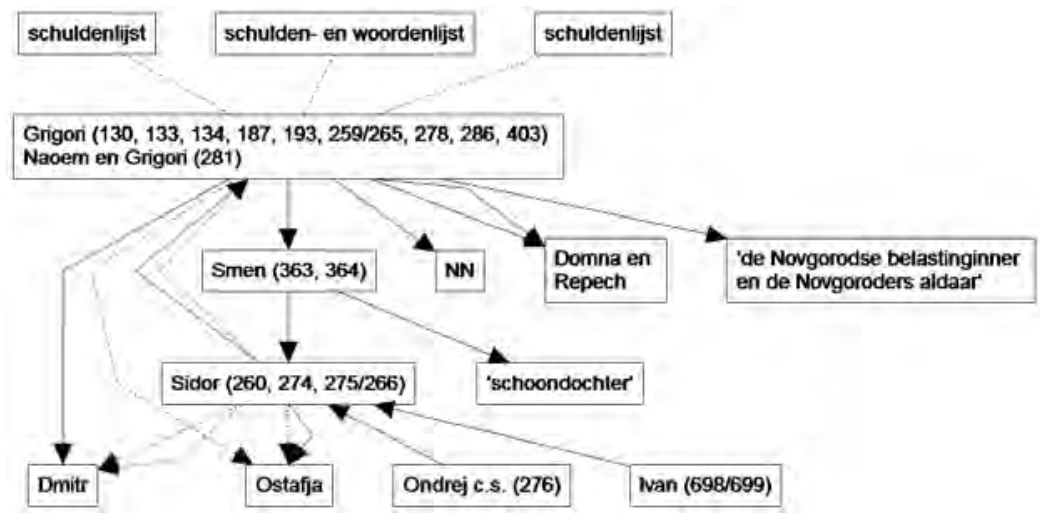

Dit netwerk laat het gehele 'oeuvre' van Grigori op berkenbast zien. Uit de tweede helft van de veertiende eeuw stammen over een periode van ongeveer dertig jaar drie schuldenlijsten (waaronder nr. 403, p. 125, inclusief een Oostzeefins-Russisch woordenlijstje) en zeven (fragmenten van) brieven. Alle documenten zijn in hetzelfde handschrift geschreven, ongetwijfeld dat van Grigori zelf.

In nr. 286 (p. 117) hebben we Grigori al zien optreden als belastinginner, maar andere brieven duiden erop dat hij daarnaast een 'senior management assistant' moet zijn geweest van een belangrijke bojaar die in de Nerev wijk woonde (zie de kaart op p. 16). Zo schrijft hij in Novgorod nr. 259/265 (ca. 1360-1380): Instructie van Grigori aan Domna. Ik heb je een emmertje steur gestuurd ..., en op het eind draagt hij de koerier van de brief op om niet lang te blijven hangen, maar terug te keren naar de plaats Loega. Een vergelijkbare tekst is Novgorod nr. 134 uit dezelfde periode: Instructie van Grigori aan Domna en aan Repech. Maak het huisje en de schuur in orde.... 
Grigori was nauw verbonden met twee andere personen die op berkenbast figureren: Smen, en vooral ook Sidor. Grigori schrijft aan Smen, Smen aan Sidor (en aan zijn schoondochter; zie nr. 363, p. 96, en het netwerk van de Misjinitsji op p. 166), en Sidor aan Grigori. Sidor noemt in zijn brieven Dmitr, die we weer kennen uit nr. 286 (p. 117). Hij schrijft ook aan Ostafja, die ook ter sprake komt in een van Grigori's brieven. Sidor en Ostafja worden overigens ook genoemd in een Duits-Russisch handelsverdrag (zie p. 17). 


\section{De Misjinitsji}

De onderstreepte namen in de stamboom van zeven generaties van het roemrijke geslacht van de Misjinitsji komen allemaal voor op berkenbast. In totaal gaat het om ongeveer vijftig brieven over een periode van 120 tot 150 jaar. Hiervan zijn de volgende opgenomen in dit boek:

- Ignat (genoemd in nr. 363, p. 166);

- zijn neef Ontsifor (de afzender van nr. 354, p. 166, en nr. 358, p. 166);

- Ontsifors zonen Maksim (afzender van nr. 177, p. 166, en nr. 253, p. 166, en geadresseerde van nr. 272, p. 166, en nr. 370, p. 166) en Joeri (eveneens geadresseerd in nr. 370);

- Joeri's zoon Michail (aan wie nr. 311, p. 166, is gericht);

- Michails vrouw Nastasja (een van de geadresseerden van nr. 307, p. 166);

- en Michails zonen Andrian en Nikita (de twee andere geadresseerden in nr. 307).

In het schema is in de derde generatie ook de naam van Ivan onderstreept. Van hem hebben we weliswaar geen brief op berkenbast, maar wel een rijk versierde houten lepel waarop staat Van Ivan, zoon van Varfolomej. De lepel is gevonden op dezelfde plek als nr. 389, geschreven door Ivans broer Loeka, van wie we uit de kronieken weten dat hij in 1342 is gestorven.

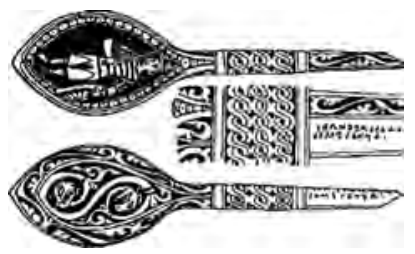




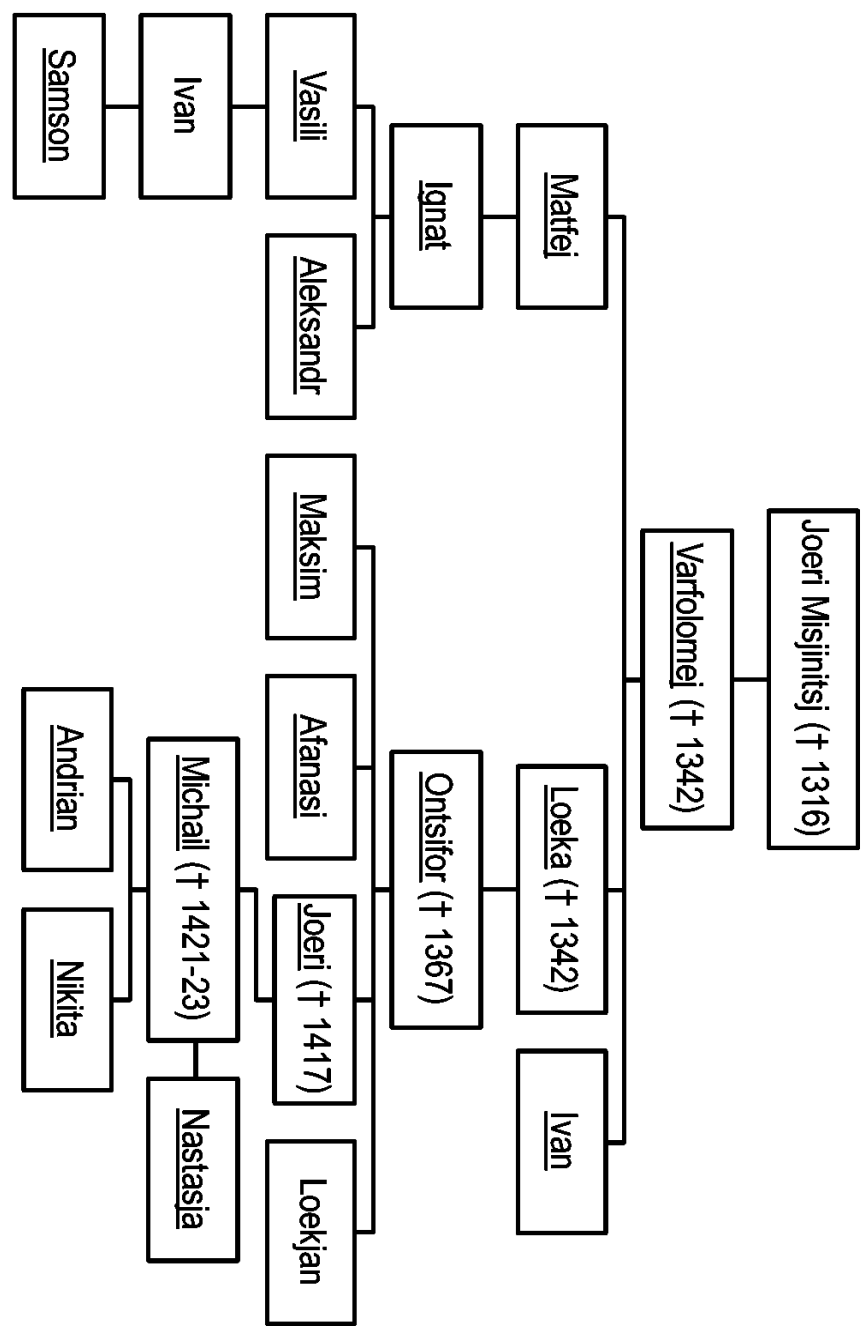





\section{Literatuur}

\section{Russischtalig}

De belangrijkste bronnen voor onderzoek naar berkenbastteksten zijn in het Russisch:

- De periodieke edities van de Russische Academie van Wetenschappen met de titel Novgorodskie gramoty na bereste [Novgorodse documenten op berkenbast], lopend van deel 1 uit 1953 (door A.V. Arcixovskij en M.N. Tixomirov; publicatie van de nrs. 1-10) tot deel 11 uit 2004 (door V.L. Janin, A.A. Zaliznjak en A.A. Gippius; nrs. 776-915 uit Novgorod, 24-36 uit Staraja Roessa en 1-19 uit Torzjok). In de latere delen worden herhaaldelijk op basis van nieuwe inzichten betere lezingen gegeven van berkenbastteksten die al eerder gepubliceerd waren.

- Voorlopige verslagen van de jaarlijkse vondsten, die gepubliceerd worden in het tijdschrift Voprosy jazykoznanija [Vragen van de taalwetenschap]. Het laatste verslag bevindt zich in vol. 2011/4 en behandelt de nrs. 974-1015 uit Novgorod en nr. 43 uit Staraja Roessa.

- Het lijvige boek Drevnenovgorodskij dialekt [Het Oudnovgorodse dialect] van A.A. Zaliznjak (Moskou 2004, 2e editie). Dit werk behandelt alle wezenlijke filologische en taalkundige zaken met betrekking tot het onderzoeksgebied en biedt uitgaven van alle belangrijke teksten die tot 2004 zijn gevonden.

- De website gramoty.ru, die behalve edities en Russische vertalingen ook foto's en tekeningen van bijna alle teksten tot en met 2005 biedt. In de rubriek Biblioteka kan Zaliznjaks boek uit 2004 gedownload worden. De website is het resultaat van een door de Europese Unie in 2004-2007 gefinancierd onderzoeksproject, gecoördineerd vanuit de Universiteit Leiden en voornamelijk uitgevoerd door een team van Russische specialisten. 
In Rusland is verder het populair-wetenschappelijke werk Ja poslal tebe berestu ... [Ik heb je een berkenbast gestuurd ...] van V.L. Janin (Moskou 1998, 3e editie) erg bekend. Van zijn hand is ook Novgorodskie posadniki [De Novgorodse posadniks (stadhouders)] (Moskou 2003, 2e editie) dat belangrijk is voor de historische context en de identificatie van personen die op berkenbast figureren. Onontbeerlijke primaire bronnen daarvoor zijn:

- De Eerste Novgorodse Kroniek, die verschillende malen is uitgegeven. Een handige editie is de Russisch-Duitse van J. Dietze: Die Erste Novgoroder Chronik (Leipzig 1971).

- Novgorodse oorkonden, die voor het laatst zijn verzameld door V.L. Janin in Novgorodskie akty XII-XV vv. [Novgorodse oorkonden van de XIIe tot de XVe eeuw] (Moskou 1991). Een encyclopedisch werk over Novgorod, met veel (achtergrond) informatie over berkenbastteksten, is Velikij Novgorod. Istorija $i$ kul'tura IX-XVII vekov. Ėnciklopedičeskij slovar' [Groot-Novgorod. Geschiedenis en cultuur van de IXe tot de XVIIe eeuw. Encyclopedisch woordenboek], red. V.L. Janin (Moskou 2009). Een zeer rijk geillustreerd boek over archeologische vondsten in Novgorod is van de hand van B. Kolčin e.a.: Drevnij Novgorod. Prikladnoe iskusstvo i arxeologija [Oud-Novgorod. Toegepaste kunst en archeologie] (Moskou 1985).

Over Novgorods rol binnen de Hanze zie E.A. Rybina, Novgorod $i$ Ganza [Novgorod en de Hanze] (Moskou 2009) en (breder georiënteerd) Torgovlja srednevekovogo Novgoroda [De handel van middeleeuws Novgorod] (Novgorod 2001). Taalkundig toegespitst is Ganza i Novgorod. Jazykovye aspekty istoričeskix kontaktov [De Hanze en Novgorod. Taalkundige aspecten van historische contacten] van E.R. Skvajrs en S.N. Ferdinand (Moskou 2002).

Voor het tweede deel van dit boek - Communicatie - is in eerste instantie gebruikgemaakt van het fundamentele artikel van A.A. Gippius, "K pragmatike i kommunikativnoj organizacii berestjanyx gramot" [Over de pragmatiek en communicatieve organisatie van berkenbastdocumenten], gepubliceerd in deel 11 van de Academie- 
editie Novgorodskie gramoty na bereste [Novgorodse documenten op berkenbast] (Moskou 2004, pp. 183-232).

\section{Anderstalig}

Over onderzoek naar berkenbastteksten is relatief weinig gepubliceerd in meer toegankelijke talen dan het Russisch. Er zijn een paar verzamelingen van teksten met commentaar:

- De verouderde beknopte anthologie van E. Melin, Einige Birkenrinde-gramoty aus Novgorod (Lund 1966).

- De collectie Iscrizioni novgorodiane su corteccia di betulla (Udine 1995) van R. Faccani, met edities en Italiaanse vertalingen van een negentigtal teksten, voorzien van korte notities.

- De syllabus Russisch op berkenbast van de elfde tot de vijftiende eeuw van W.R. Vermeer (Leiden 1999, 3e druk). Deze interne publicatie concentreert zich met name op de taalkundige aspecten van berkenbastteksten.

Voor de cultuurhistorische en filologische context waarin schrijven op berkenbast in middeleeuws Rusland gezien moet worden is het boek Writing, Society and Culture in Early Rus, c. 950-1300 van S. Franklin (Cambridge 2002) aan te raden. Toegespitst op middeleeuws Novgorod zijn de twee bundels met artikelen van H. Birnbaum: Lord Novgorod the Great (Columbus OH 1981) en Novgorod in Focus (Columbus OH 1996).

Over Novgorod en de Hanze zie de bundel Novgorod. Markt und Kontor der Hanse, red. N. Angermann en K. Friedland (Köln 2002). Een goed boek dat veel informatie biedt over Novgorods internationale handelspositie in de Middeleeuwen is van Janet Martin: Treasures of the Land of Darkness. The Fur Trade and its Significance for Medieval Russia (Cambridge 1986). Zie ook E. Mühle, Die städtischen Handelszentren der nordwestlichen Rus' (Stuttgart 1991).

De resultaten van archeologisch onderzoek in Novgorod, ook in relatie tot berkenbastteksten, worden besproken in Novgorod: the Archaeology of a Russian Medieval City and its Hinterland, red. M. 
Brisbane en D. Gaimster (London 2001), en in Wood Use in Medieval Novgorod, red. M. Brisbane en J. Hather (Oxford 2007).

In het tijdschrift Russian Linguistics staan in vol. 35/1 en 35/3 van 2011 meerdere Engelstalige artikelen (van D.E. Collins, A.A. Gippius en J. Schaeken) die betrekking hebben op het onderwerp van het tweede deel van dit boek - communicatie op berkenbast - en die als vervolgstudies kunnen gelden op het bovengenoemde Russischtalige artikel van Gippius uit 2004. Gippius gaat verder in op de thematiek in zijn bijdrage "Birchbark Literacy and the Rise of Written Communication in Early Rus"' in de bundel Epigraphic Literacy and Christian Identity: Modes of Written Discourse in the Newly Christian European North, red. J. Jesch en K. Zilmer (Turnhout 2012).

In de laatstgenoemde bundel is ook een overzichtsartikel opgenomen (J. Schaeken, "The Birchbark Documents in Time and Space revisited"), met o.a. aandacht voor de overeenkomsten en verschillen tussen berkenbastteksten en het corpus middeleeuwse houten runenstaafjes uit Bergen, Noorwegen, waarvan de inhoud soms erg doet denken aan wat we op berkenbast aantreffen. Over andere parallellen met brieven uit oudere periodes (dunne houten tabletten uit Vindolanda, Northumbria; papyri uit Oxyrhynchus, Egypte) schrijft Franklin, Writing, Society and Culture ... (zie boven) op pp. 35-45.

Over de middeleeuwse schrijfcultuur op berkenbast is een Franse filmdocumentaire van vijftig minuten gemaakt door Marc Jampolsky: Novgorod, Lettres du Moyen Age (2004). 


\section{Lijst van teksten}

Uit Novgorod

184

995

1585

2379

2431

2930

4385

46100

4986

5362

79142

10955

134164

13674

14240

15465

15556

$177 \quad 152$

186154

199102

200101

202101

203103

205104

206104

207103

24157

24658

24754
$248 \quad 118$

253151

259/265 164

272119

286117

292124

30780

31176

331103

34448

354149

358148

36178

36396

36496

37072

37789

$397 \quad 145$

$403 \quad 125$

406158

419112

420156

42164

$422 \quad 137$

42447

43944

443145

47777

488128
49551

$497 \quad 147$

50261

509153

$519 / 52070$

52171

53198

538115

549111

55069

552129

56688

57863

58642

589133

590120

591105

605107

$607 / 56267$

636121

64494

656146

674114

682108

687106

692110

704121

705136

715113 
$\begin{array}{lll}717 & 109\end{array}$

72242

$\begin{array}{lll}724 & 122\end{array}$

$731 \quad 89$

$\begin{array}{lll}734 \quad 113 \\ 735 & 138\end{array}$

$\begin{array}{lll}735 & 138\end{array}$

73649

739138

$745 \quad 144$

$750 \quad 135$

75287

$753 \quad 126$

75566

$\begin{array}{lll}771 & 157\end{array}$

83131

$872 \quad 162$

879139

88156

90268

90759

91234

$913 \quad 34$

915-I 111

92643

$952 \quad 134$

95492

95590

963116

999163

100052

1004140

1006141

100952

\section{Uit andere steden}

Pskov 645

Smolensk 11127

Staraja Roessa 1073

Staraja Roessa 1146

Staraja Roessa 15150

Staraja Roessa 3550

Staraja Roessa 3946

Staraja Roessa 4097

Torzjok 10143

Tver 222

Tver 575

Zvenigorod 2159 


\section{Ter verantwoording}

De originelen van de berkenbastteksten uit Novgorod worden merendeels bewaard in het Novgorods Verenigd Staatsmuseum ( $w w w$. novgorodmuseum.ru) en in het Staats-Historisch Museum ( $w w w$. shm.ru) in Moskou. Van de meeste teksten zijn tekeningen en foto's beschikbaar (copyright V.L. Janin, Moskou). De tekeningen worden sinds het begin van de jaren vijftig gemaakt door een team van Russische specialisten.

De plattegrond van Novgorod (p. 16) is een bewerking van een Russischtalige versie die in verschillende boeken te vinden is, waaronder Velikij Novgorod: Istorija i kul'tura ... (zie boven, p. 170), pp. 78-79.

De kaart met handelsroutes rondom Novgorod (p. 17) is een bewerking van een versie die o.a. te vinden is op p. 30 van Rybina's boek Novgorod i Ganza (zie boven, p. 170).

De kaart met het verspreidingsgebied van berkenbastvondsten ( $\mathrm{p}$. 20 ) is een update van de versie in J. Schaeken, Oudrussisch voor russisten (Leiden 2004), p. 9.

De grafiek die de chronologie van berkenbastvondsten weergeeft (p. 25), is ook te vinden in het artikel "The Birchbark Documents in Time and Space revisited" van J. Schaeken (zie boven, p. 172).

De afbeelding van de houten cilinder met daarop de naam Choten (p. 68) is afkomstig uit V.L. Janin, $U$ istokov novgorodskoj gosudarstvennosti [Aan de wieg van het Novgorodse staatsbestel] (Novgorod 2001), p. 122.

De foto van de Novgorodse Codex (p. 103) is op vele plaatsen gepubliceerd, o.a. in Velikij Novgorod: Istorija i kul'tura ... (zie boven, p. 170), p. 356.

De afbeelding van het wastafeltje op p. 105 is overgenomen uit E.A. Rybina's bijdrage "Mirror frames and wax tablets" in Wood Use in Medieval Novgorod (zie boven, p. 172), p. 339.

Het varkensbot met runenalfabet uit Novgorod (p. 127) is afge- 
beeld in E.A. Makaev, "Runičeskaja nadpis' iz Novgoroda" [Een runeninscriptie uit Novgorod], Sovetskaja arxeologija [Sovjet-Archeologie], 1962/3, p. 310 .

De afbeelding van de houten lepel van Ivan, zoon van Varfolomej (p. 166), is overgenomen uit deel 9 (1993) van Novgorodskie gramoty na bereste (zie boven, p. 169), p. 115.

De stamboom die bij het sociale netwerk van de Misjinitsji is afgebeeld (p. 166) is gebaseerd op de Russische versie op p. 511 van Zaliznjaks boek Drevnenovgorodskij dialekt (zie boven, p. 169).

De foto's van Novgorod en de opgravingen (p. 81 e.v.) alsmede de foto van de twee schrijfstiften op p. 29 zijn gemaakt door de auteur. 